\title{
Synthesis 橉Thieme
}

\section{Multicomponent diastereoselective synthesis of indolizidines via 1,3-dipolar cycloadditions of azomethine ylides}

\begin{tabular}{|c|c|}
\hline Journal: & SYNTHESIS \\
\hline Manuscript ID & SS-2016-07-0541-OP.R1 \\
\hline Manuscript Type: & Original Paper \\
\hline Date Submitted by the Author: & $\mathrm{n} / \mathrm{a}$ \\
\hline Complete List of Authors: & $\begin{array}{l}\text { Selva, Veronica; Universitat d'Alacant Facultad de Ciencies, Organic } \\
\text { Chemistry } \\
\text { Castello, Luis; University of Alicante, Organic Chemistry } \\
\text { Najera, Carmen; University of Alicante, Organic Chemistry } \\
\text { Sansano, Jose; University of Alicante, Organic Chemistry }\end{array}$ \\
\hline Keywords: & $\begin{array}{l}\text { cycloaddition, fused-ring systems, heterocycles, multicomponent reaction, } \\
\text { diastereoselectivity }\end{array}$ \\
\hline Abstract: & $\begin{array}{l}\text { The synthesis of polyfunctionalized indolizidines from pipecolinic acid alkyl } \\
\text { ester derivatives, aldehydes and a wide range of dipolarophiles by a } \\
\text { multicomponent } 1,3 \text {-dipolar cycloadditions has been developed in a } \\
\text { diastereselective manner. Reactions take place in toluene with short } \\
\text { reaction times at } 70{ }^{\circ} \mathrm{C} \text {, giving good yields. The synthesis of these fused } \\
\text { heterocycles is also studied starting from the pipecolinic acid, generating } \\
\text { the dipole through a decarboxylative route at } 120{ }^{\circ} \mathrm{C} \text {. The relative } \\
\text { configuration of the resulting products, as well as the mechanistic } \\
\text { pathways are also explained. }\end{array}$ \\
\hline
\end{tabular}




\section{SUPPORTING INFORMATION}

\section{Multicomponent diastereoselective synthesis of indolizidines via 1,3-dipolar cycloadditions of azomethine ylides}

$$
\text { Castelló, Luis M. }{ }^{a, b} \text { Selva, Verónica }{ }^{a, b} \text { Nájera, Carmen }{ }^{a} \text { Sansano, José M., }
$$

a Departamento de Química Orgánica. Facultad de Ciencias, Universidad de Alicante, 03080-Alicante, Spain. Centro de Innovación en Química Avanzada (ORFEO-CINQA).

${ }^{b}$ Instituto de Síntesis Orgánica (ISO). Universidad de Alicante, 03080-Alicante, Spain.

*cnajera@ua.es.

Table of contents

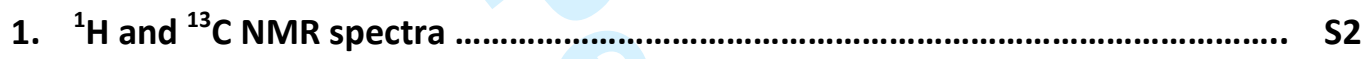

2. X-Ray diffraction analysis of compound endo-13 ............................................... S25 
1. ${ }^{1} \mathrm{H}$ and ${ }^{13} \mathrm{C}$ NMR spectra
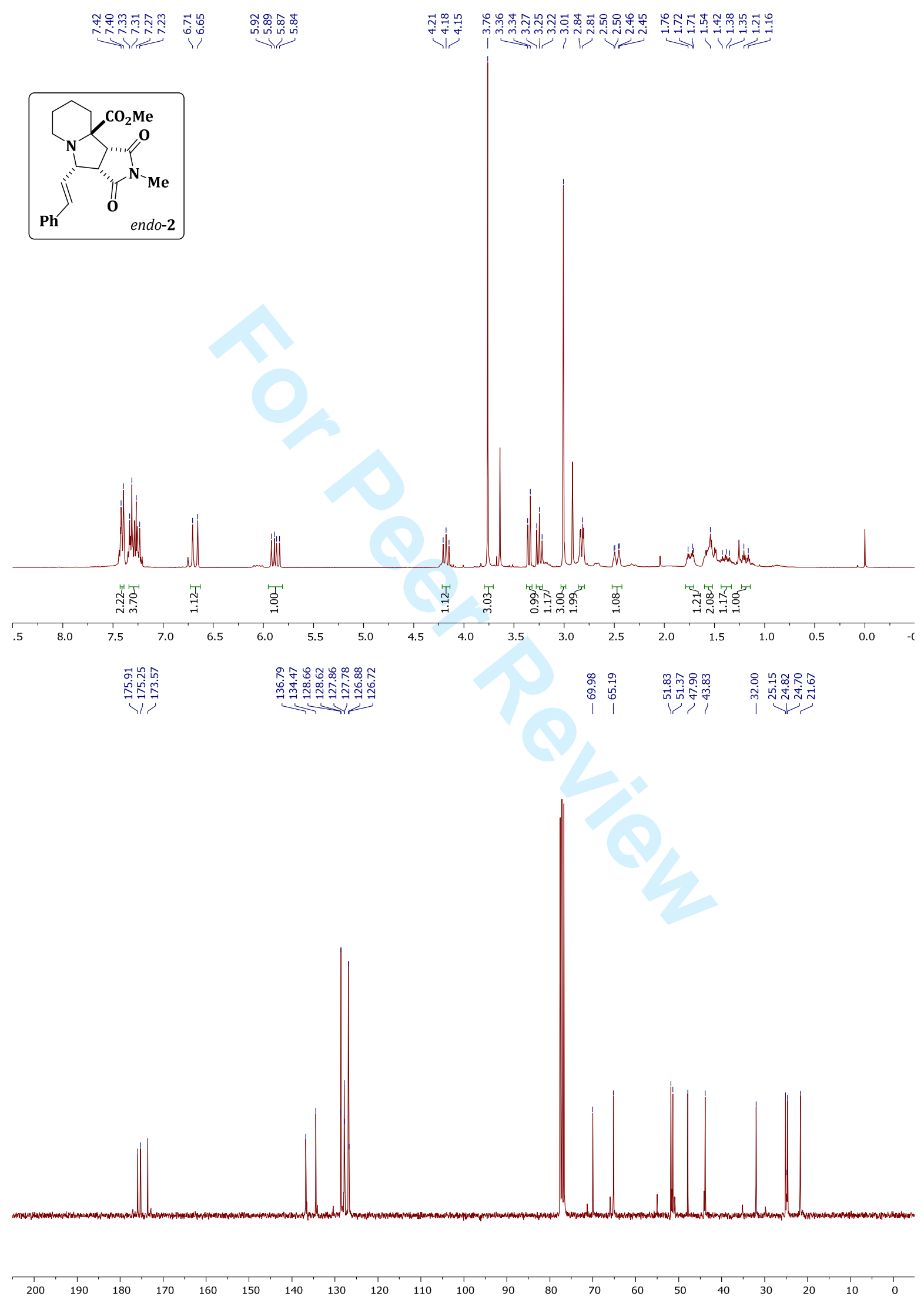

Georg Thieme Publishers KG, Rüdigerstraße 14, 70469 Stuttgart, Germany 

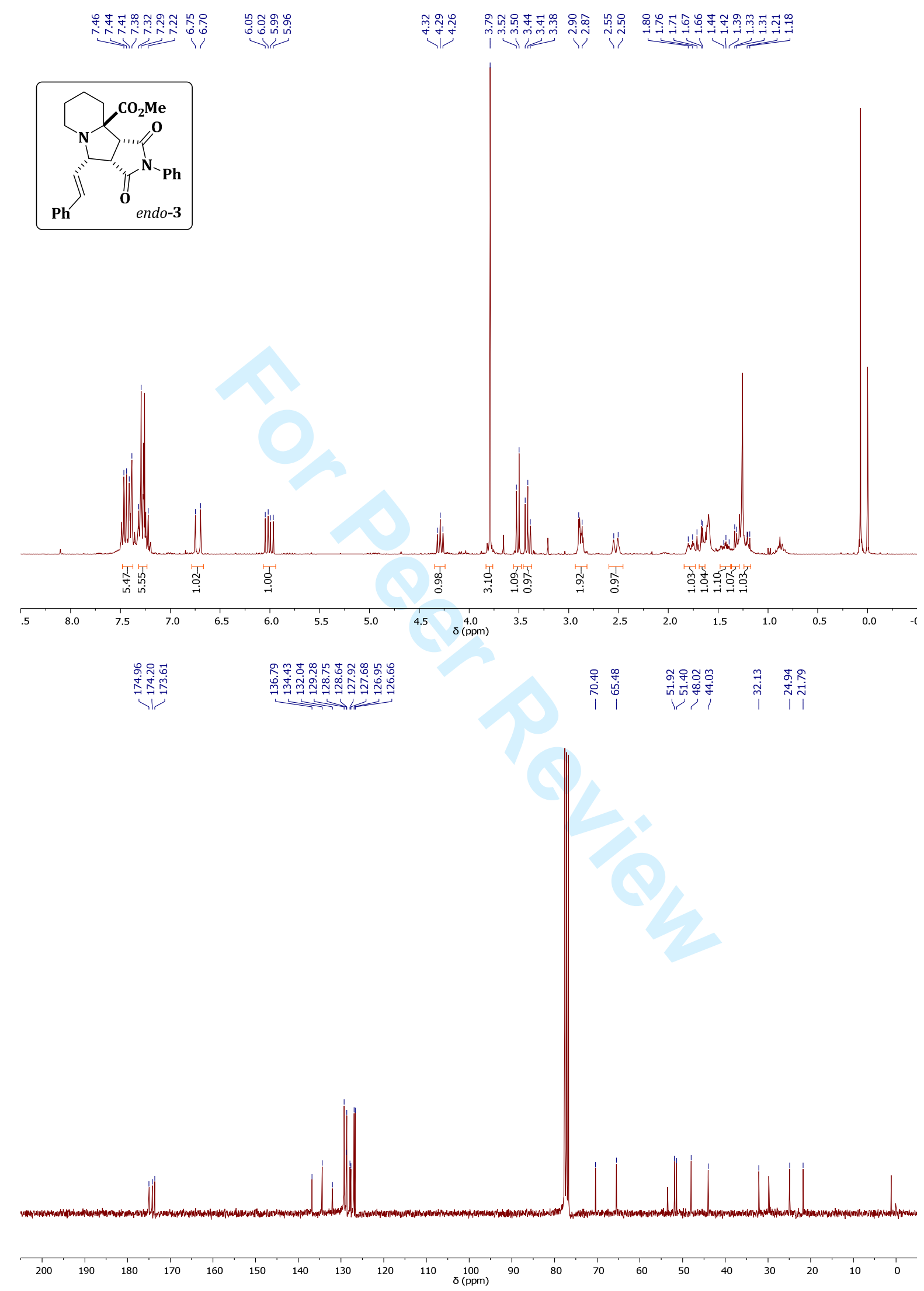

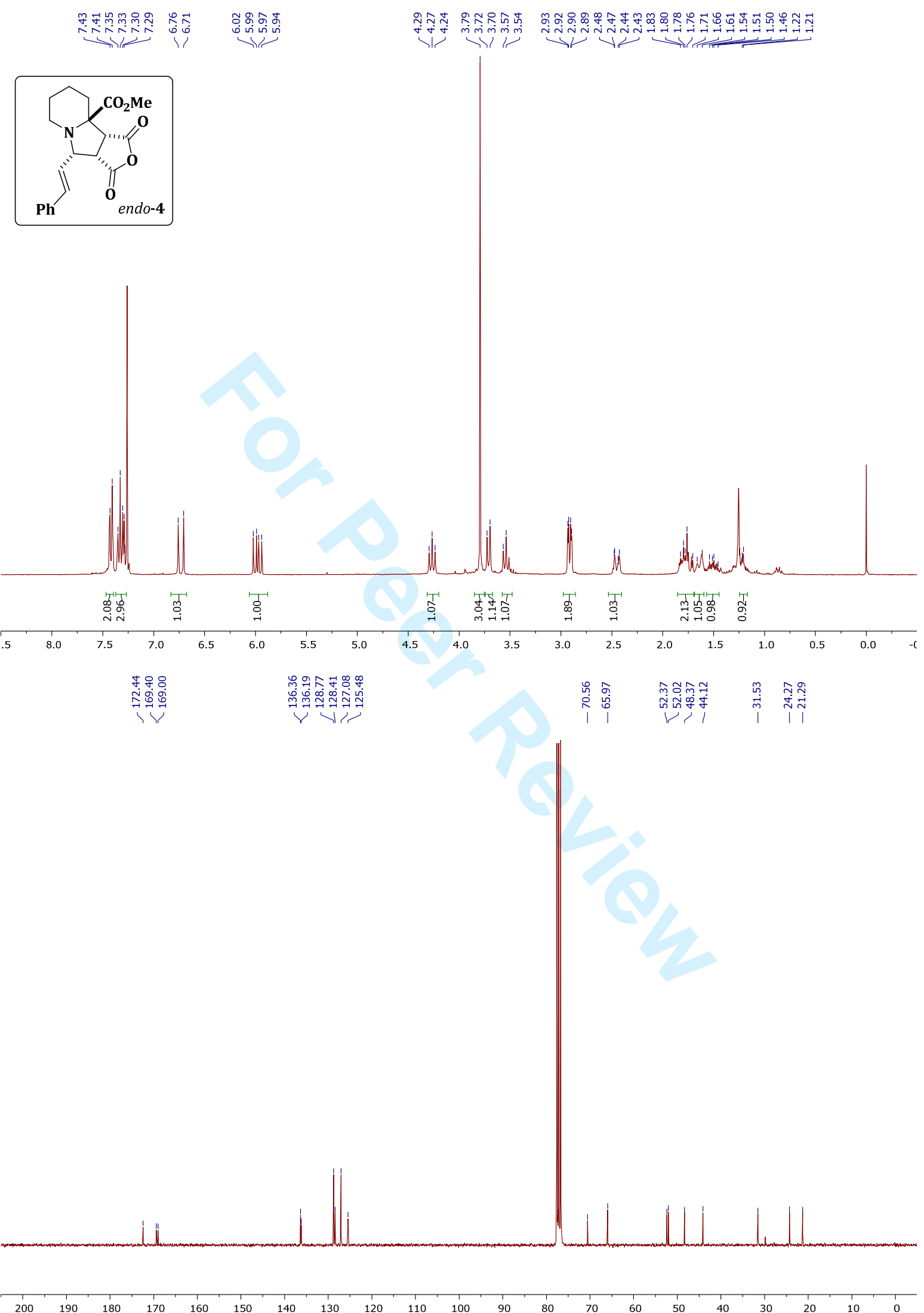

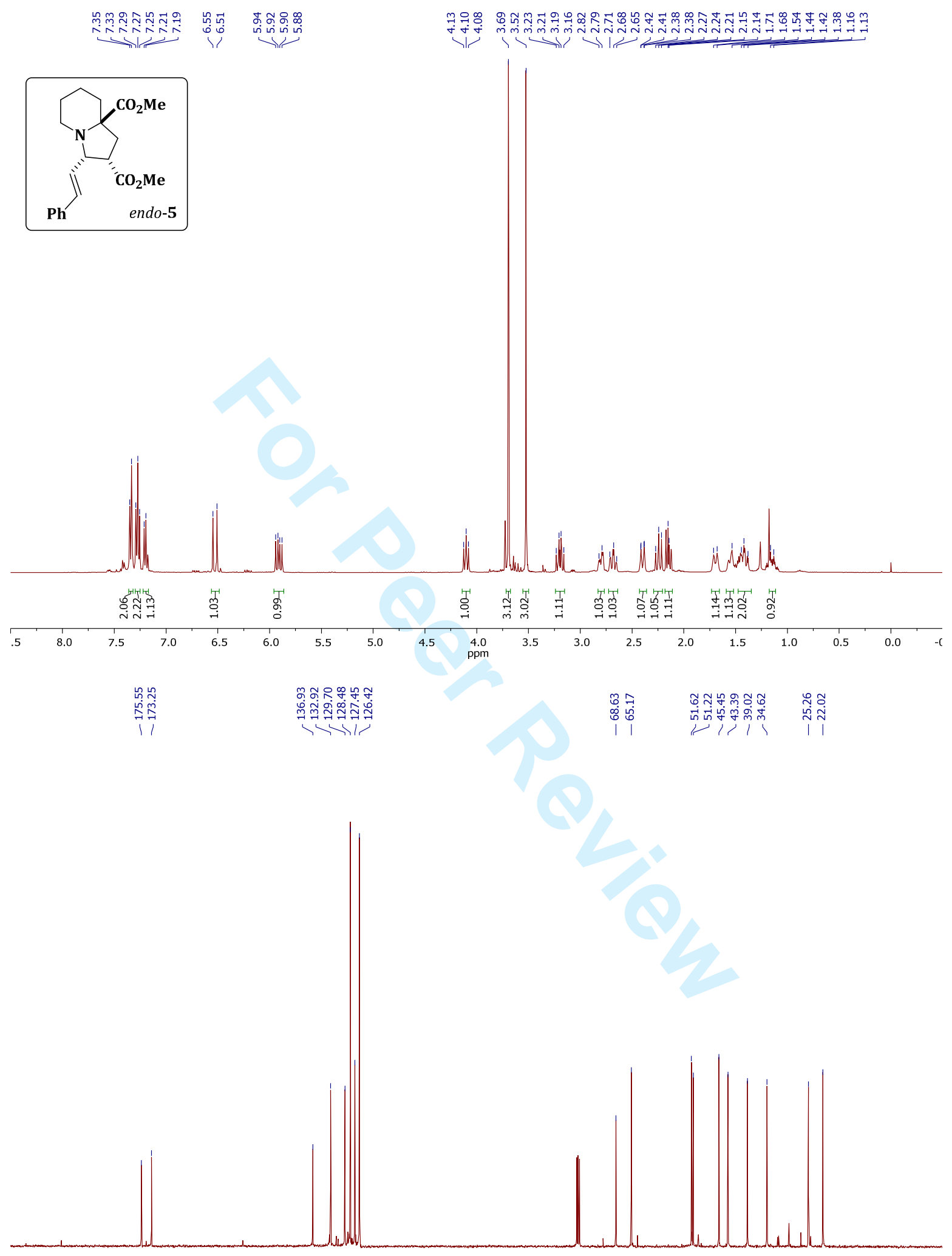

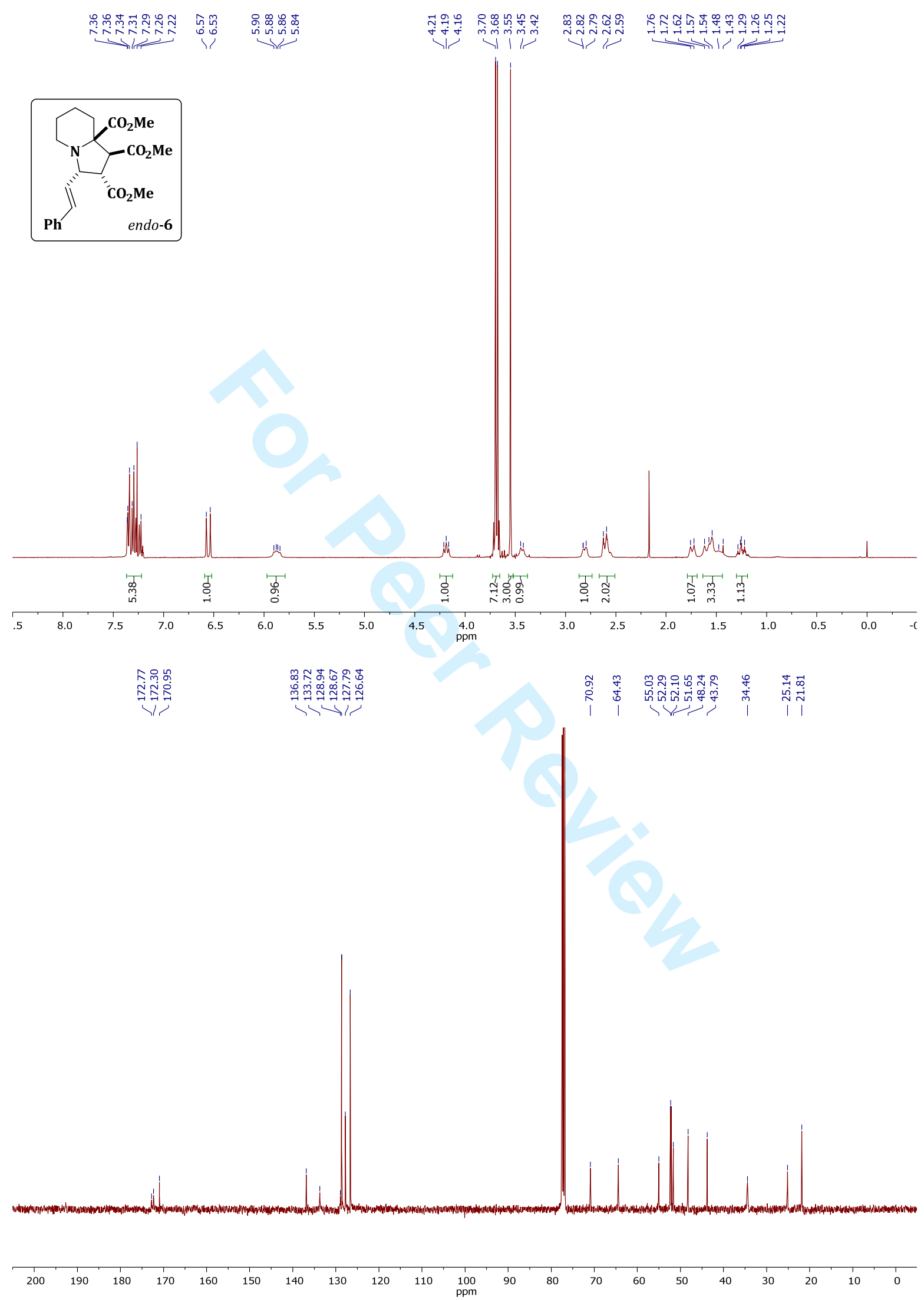

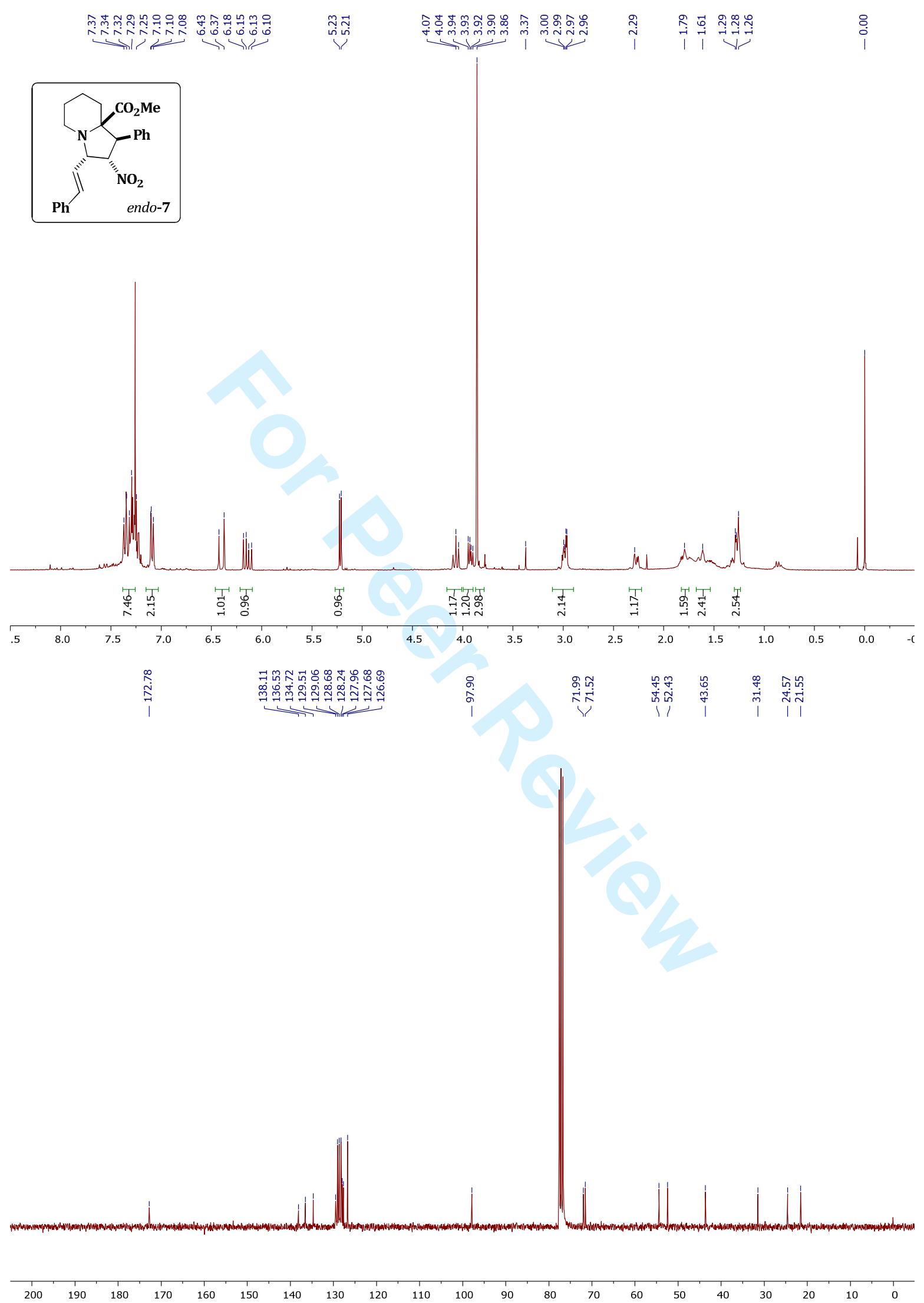

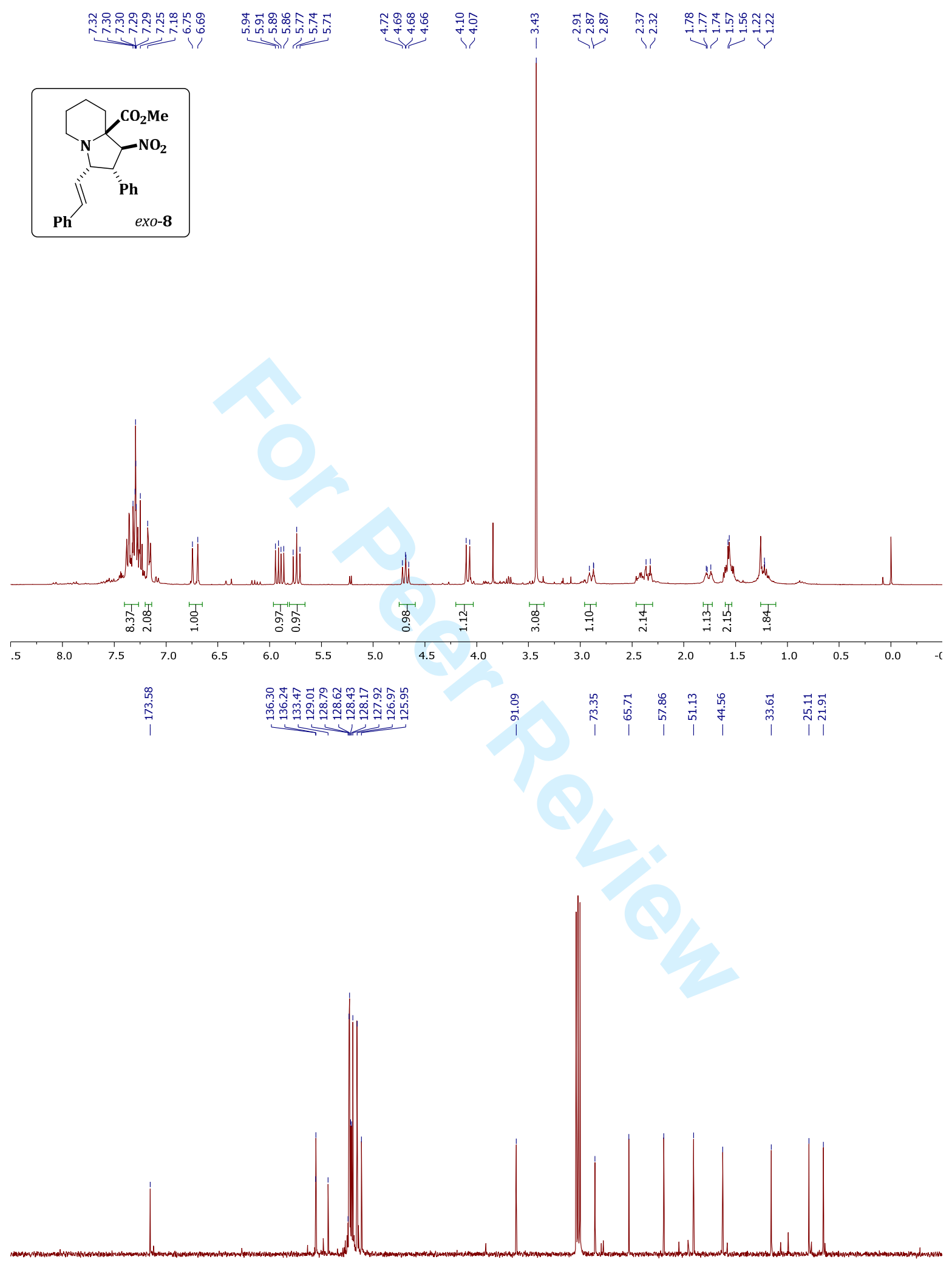

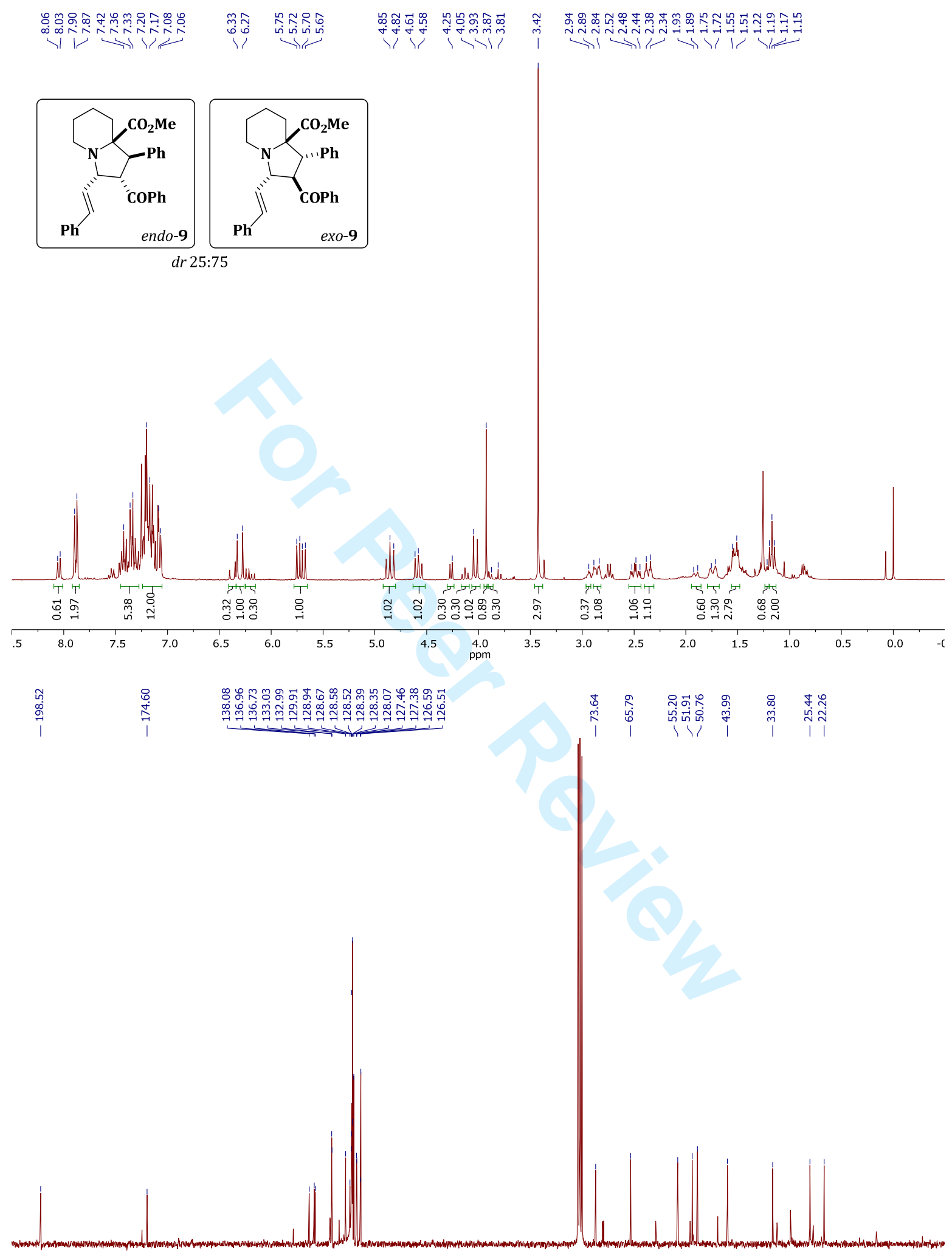


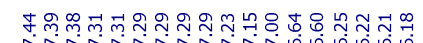

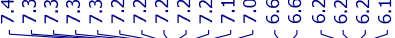

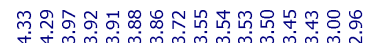

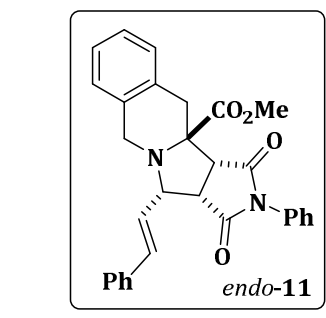

11
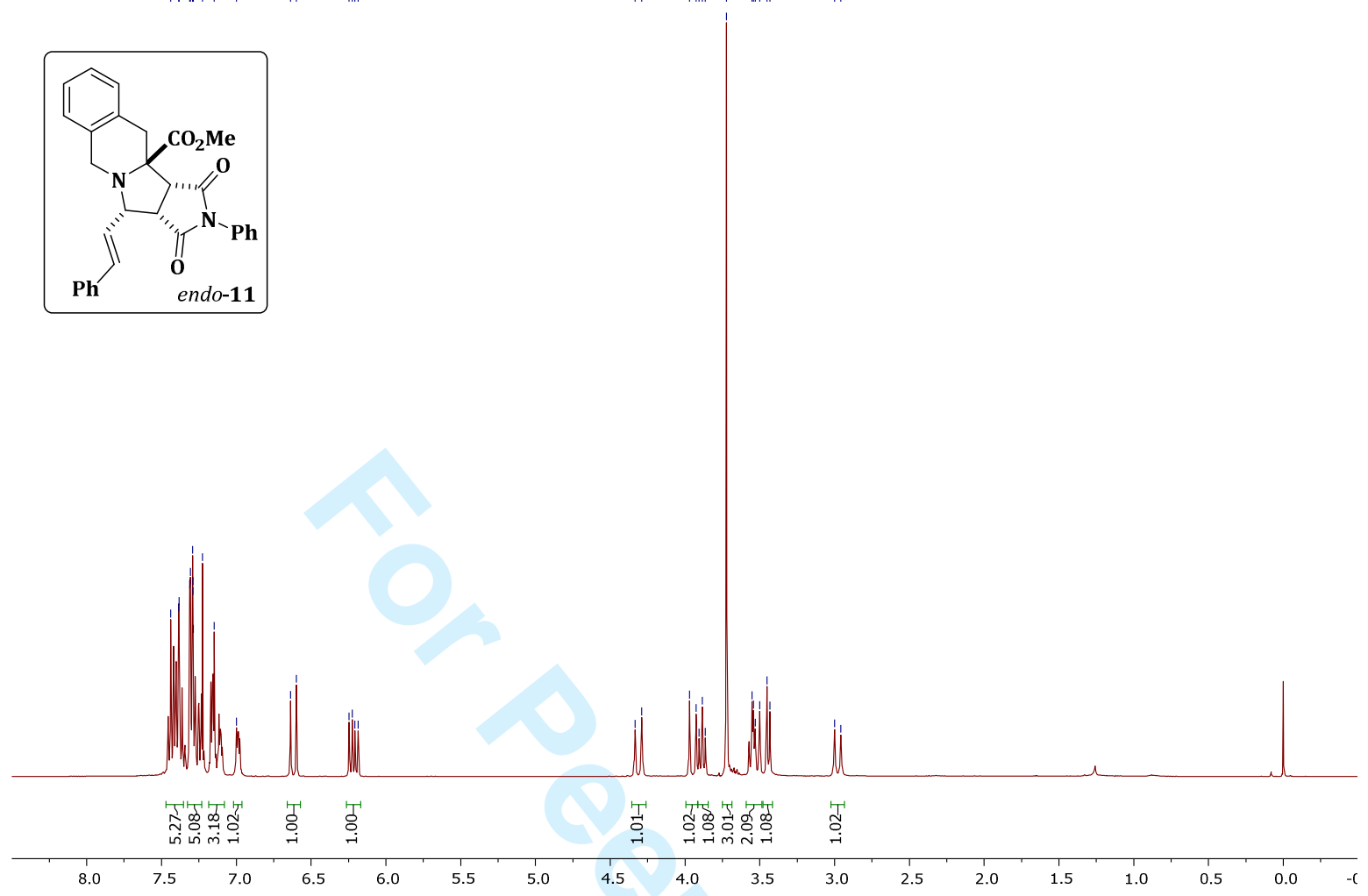

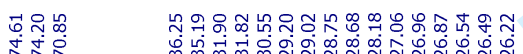

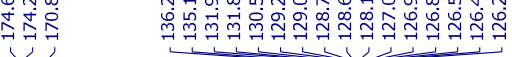

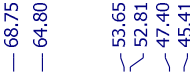

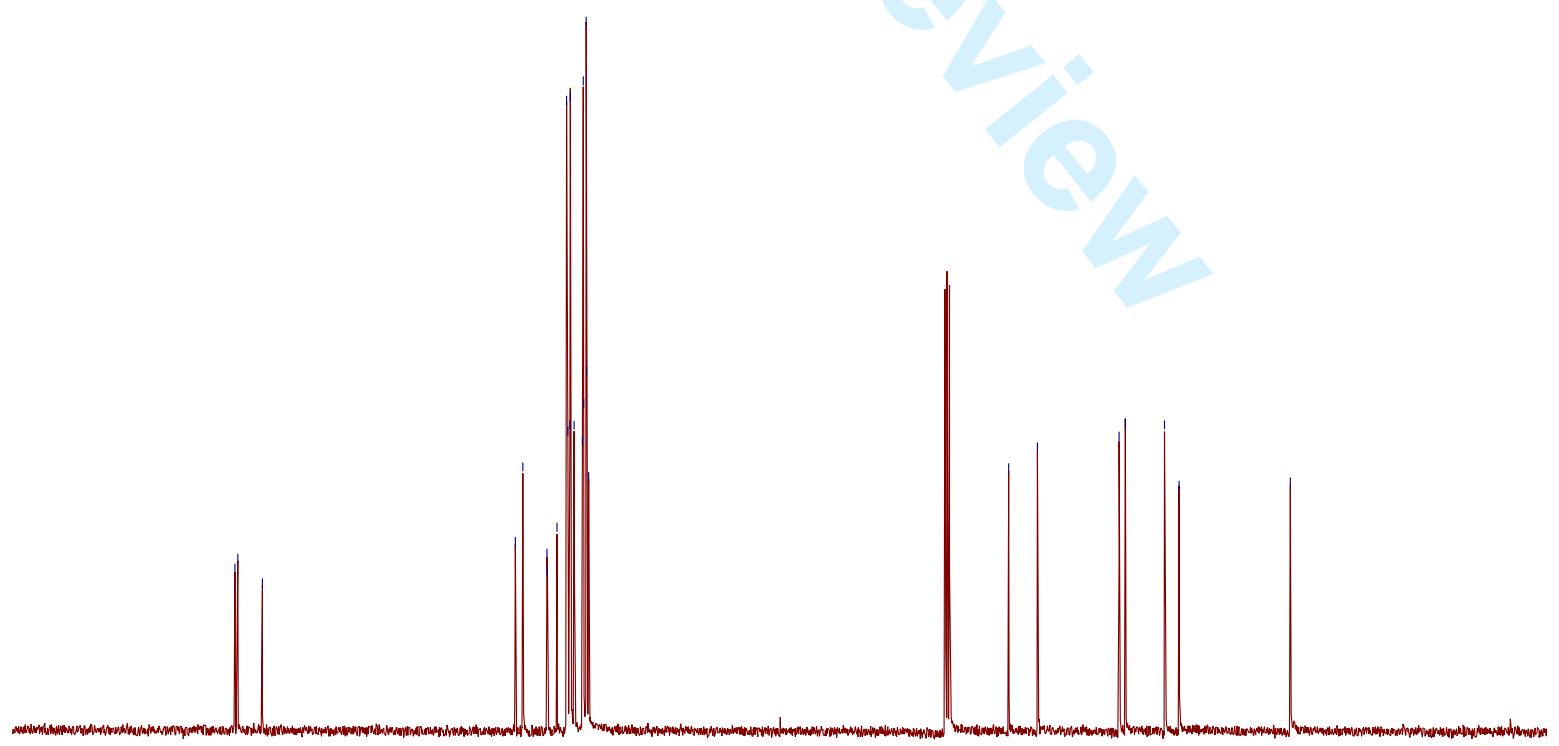

S10

Georg Thieme Publishers KG, Rüdigerstraße 14, 70469 Stuttgart, Germany 

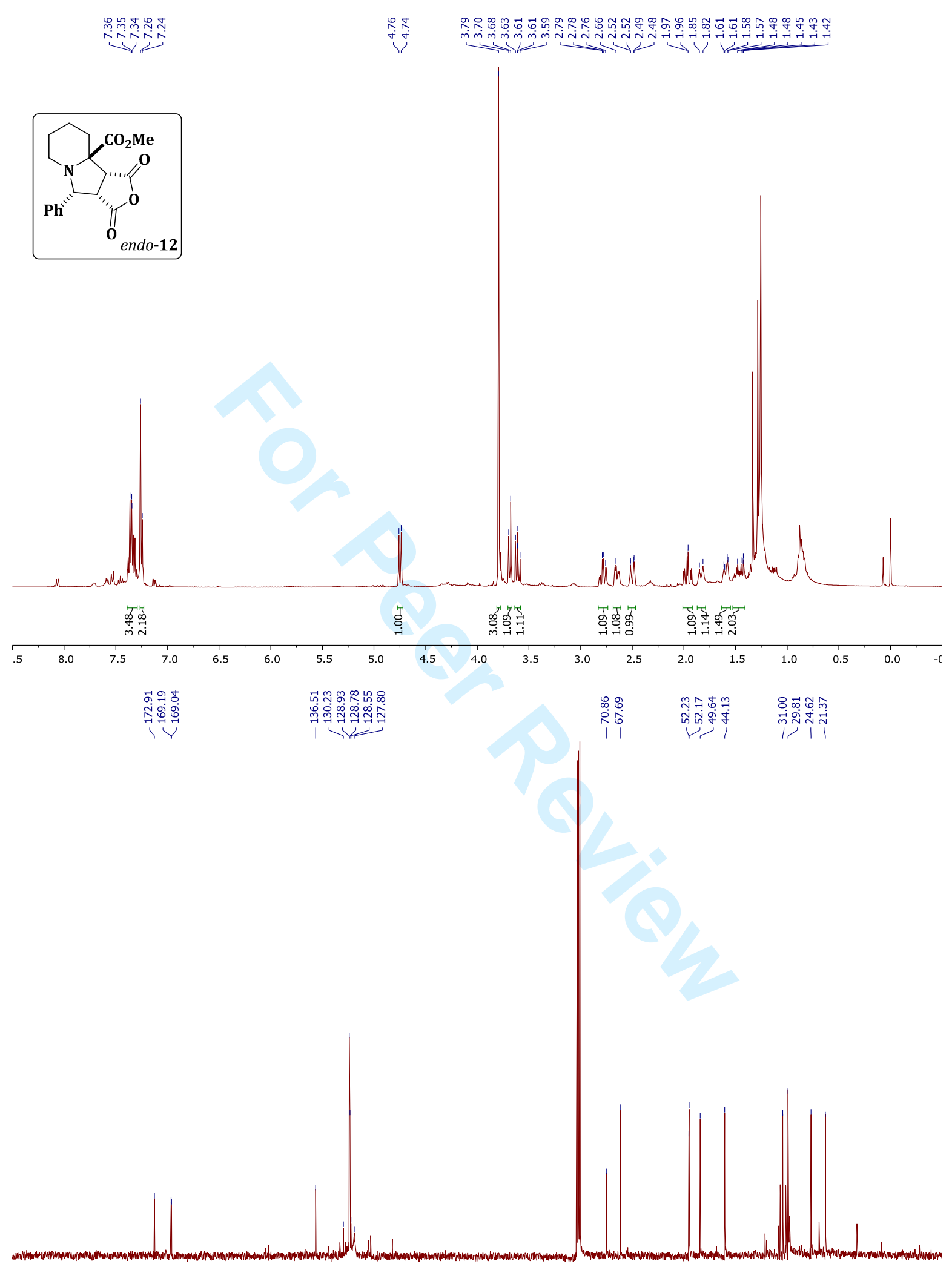

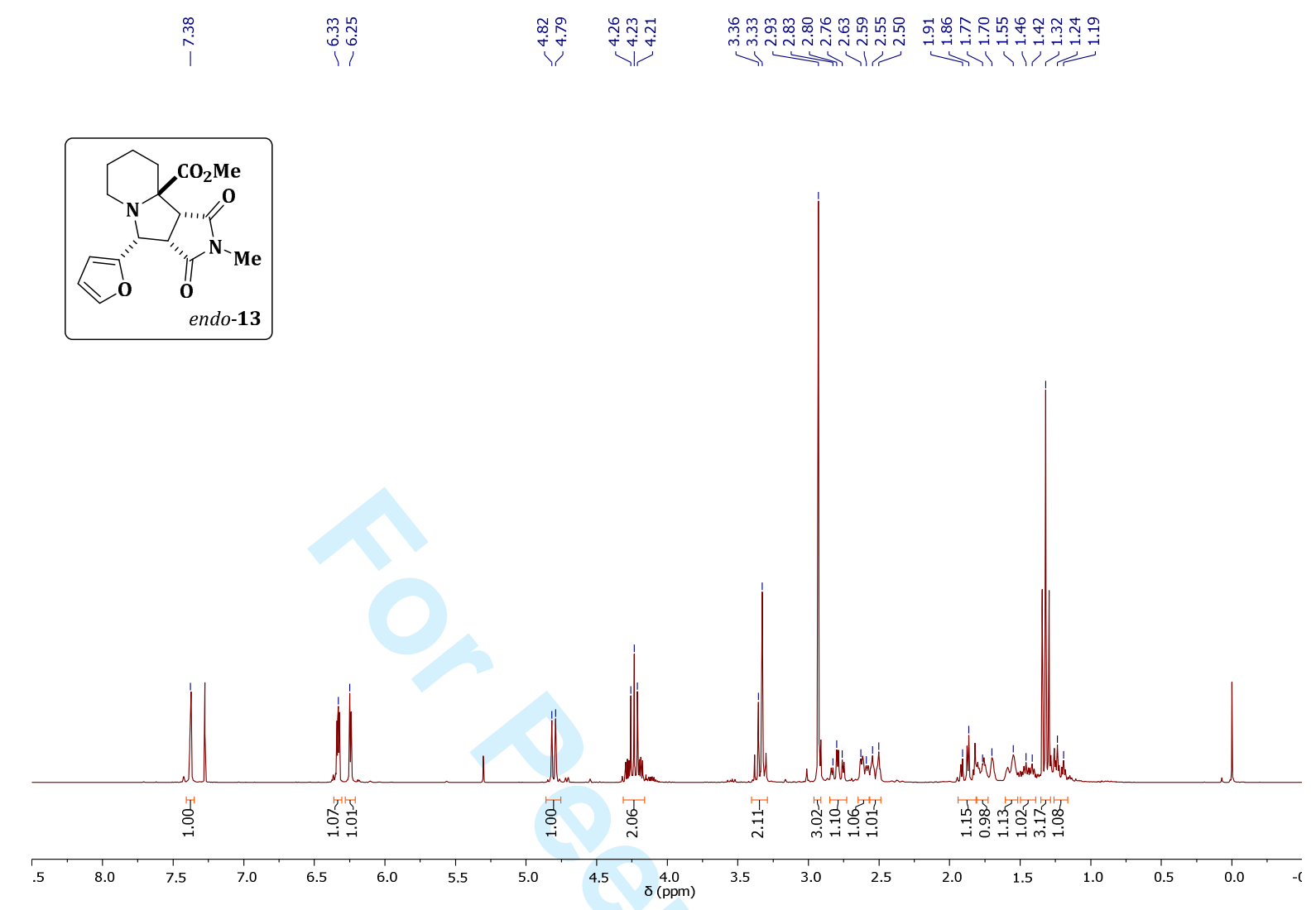

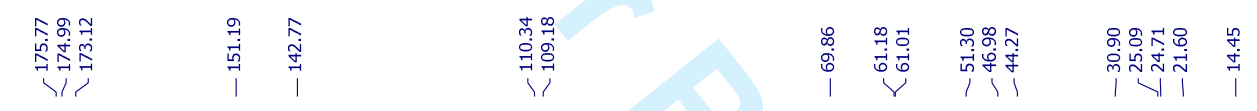

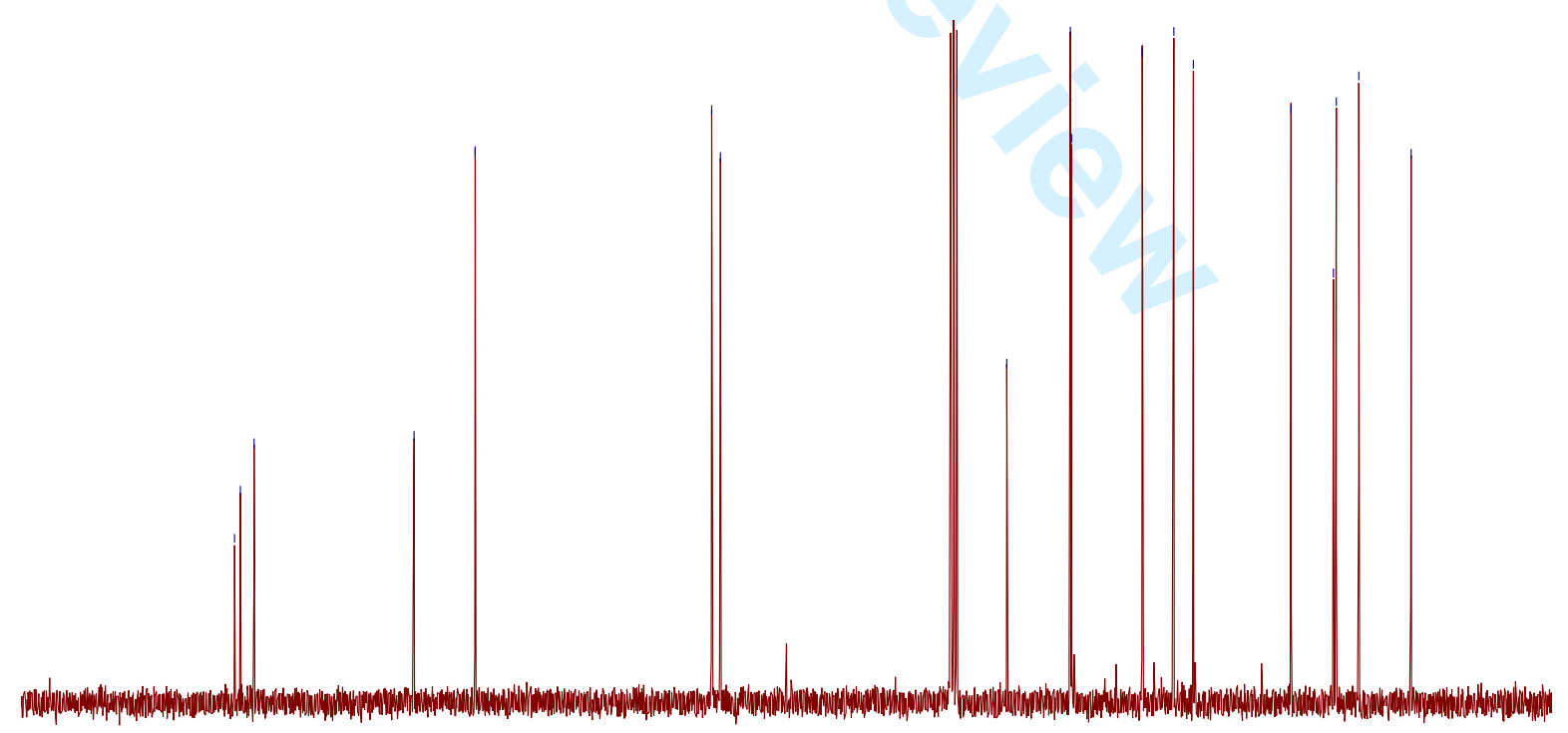



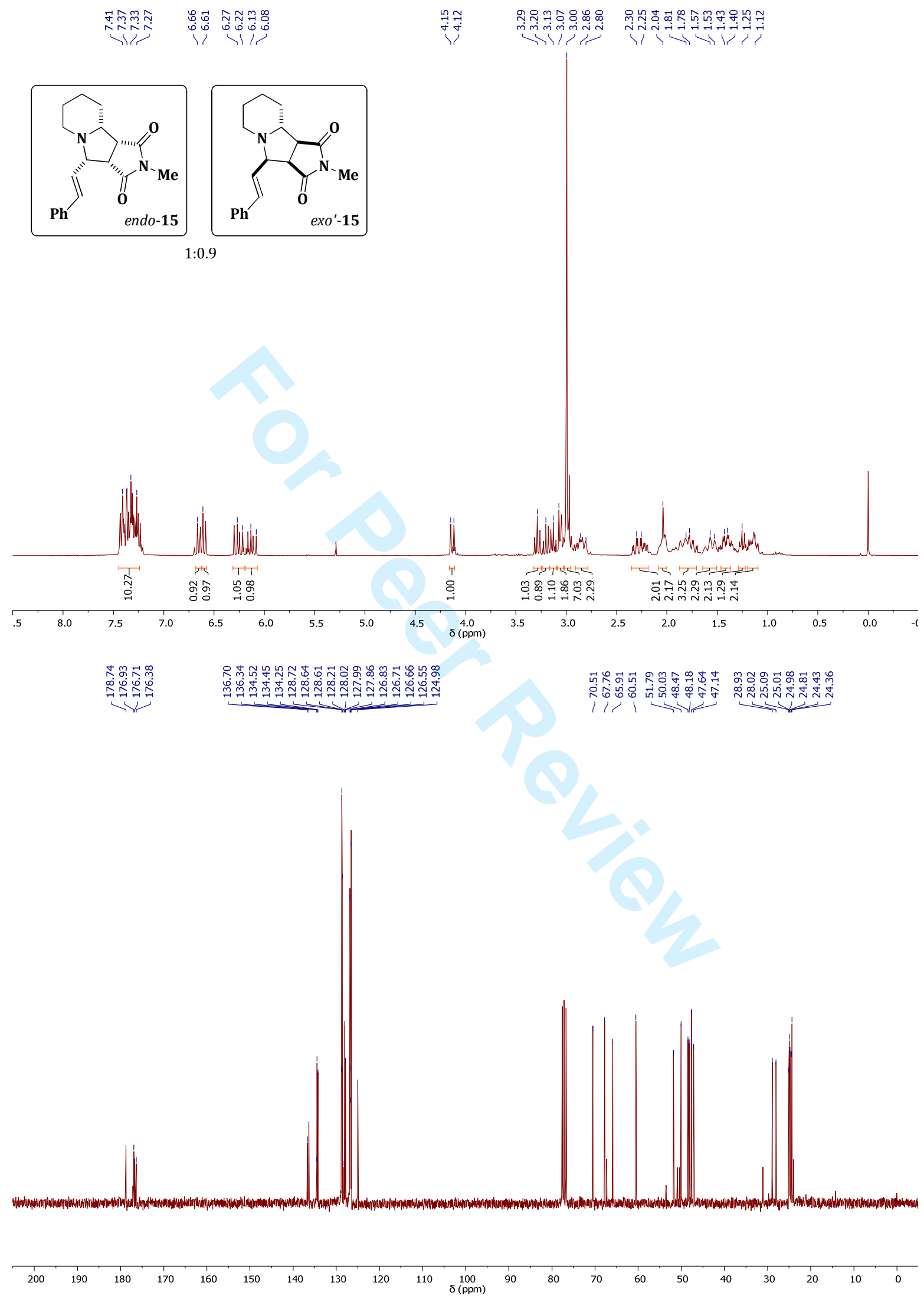

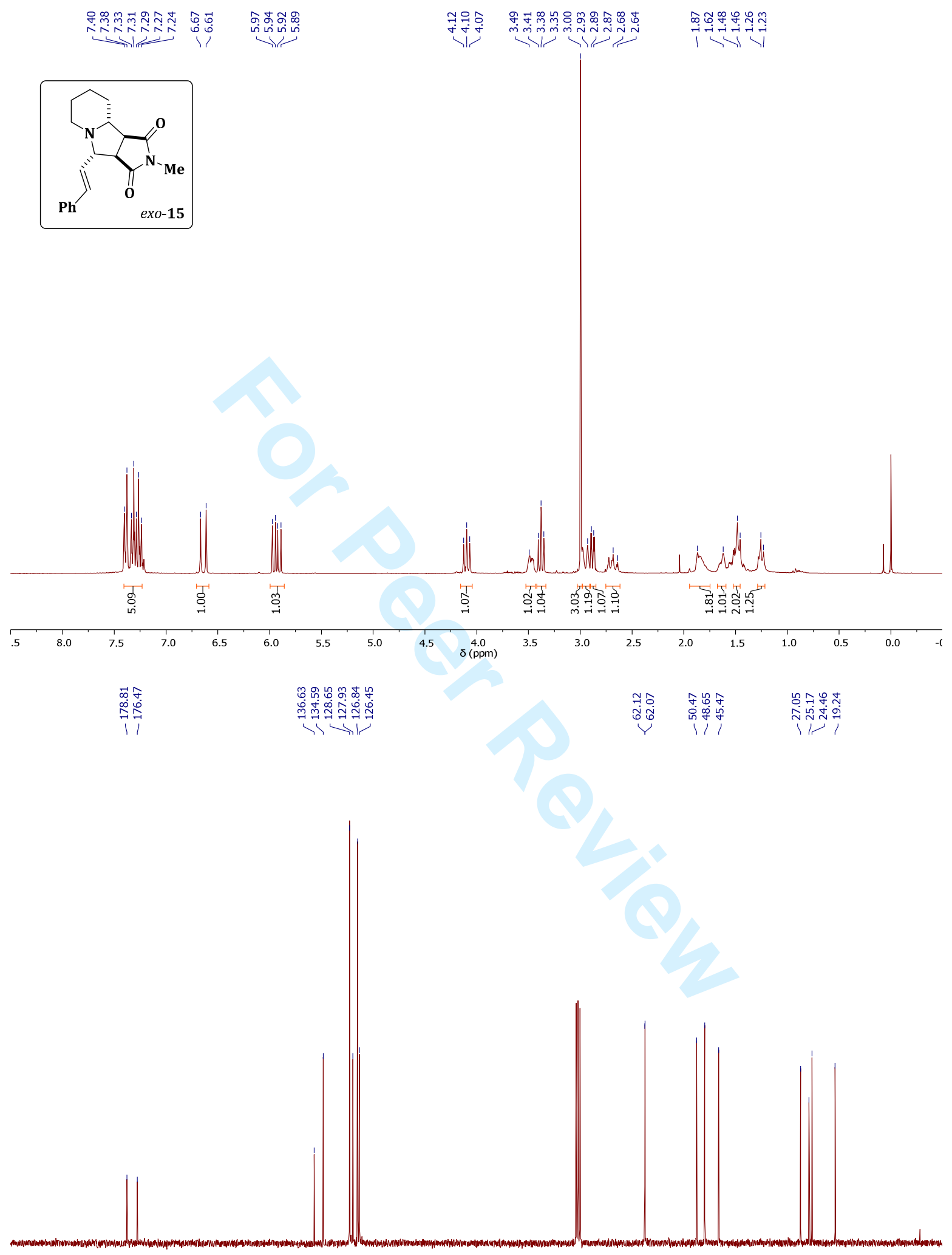


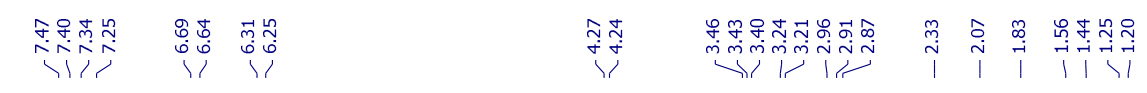
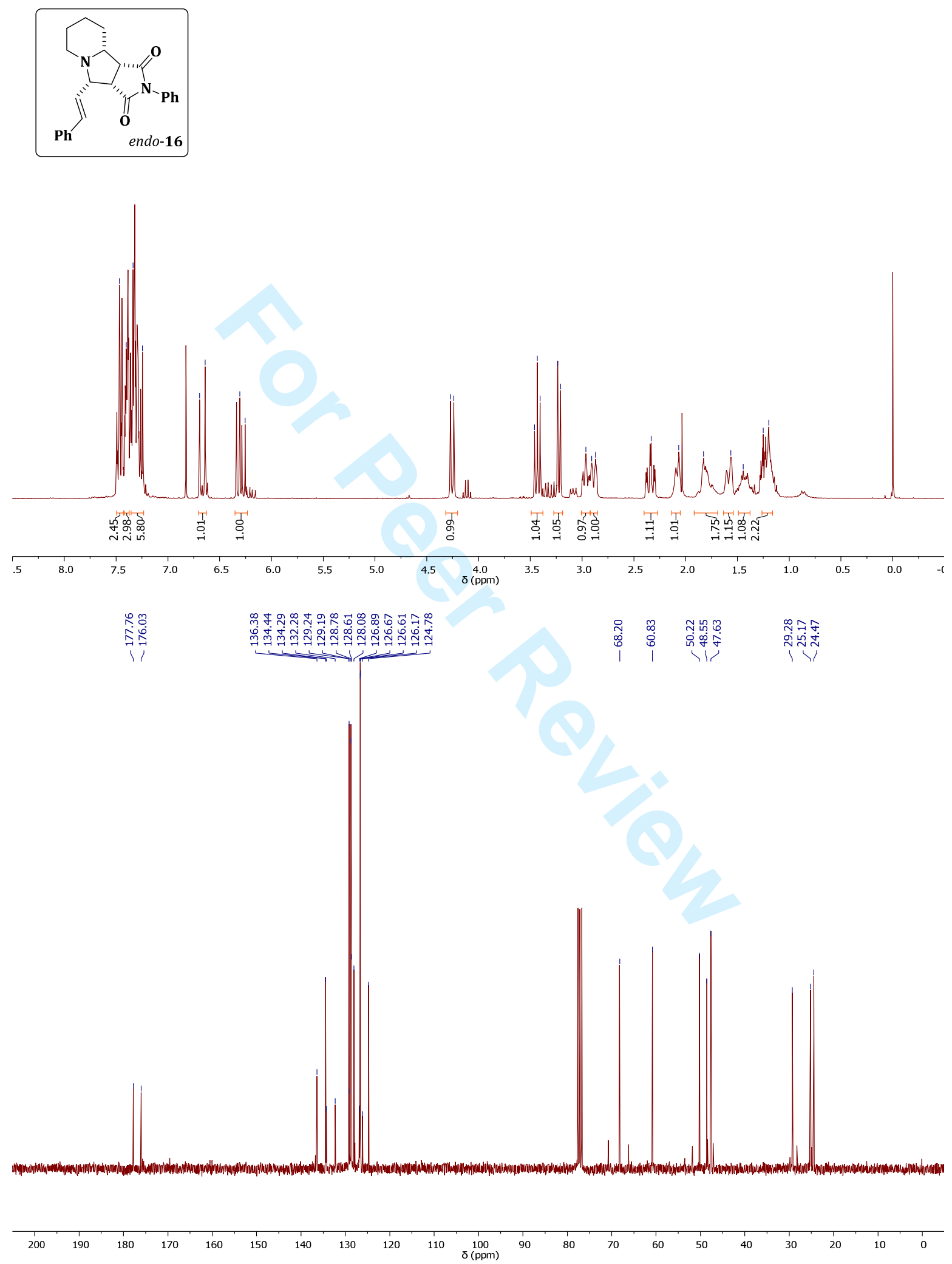


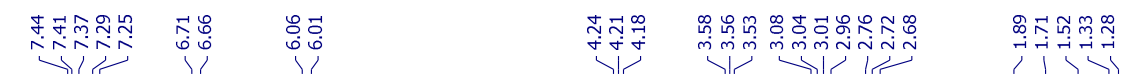
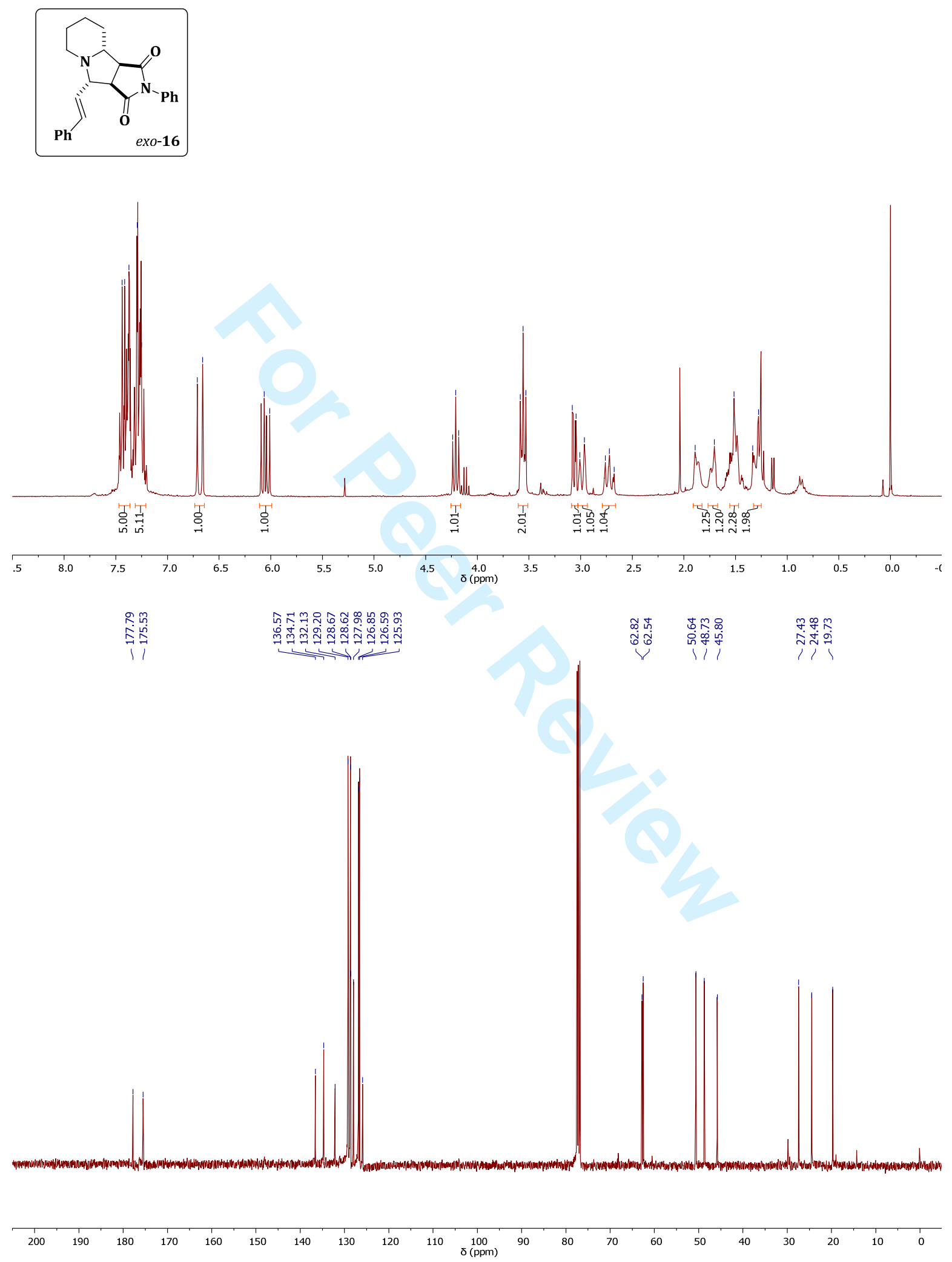

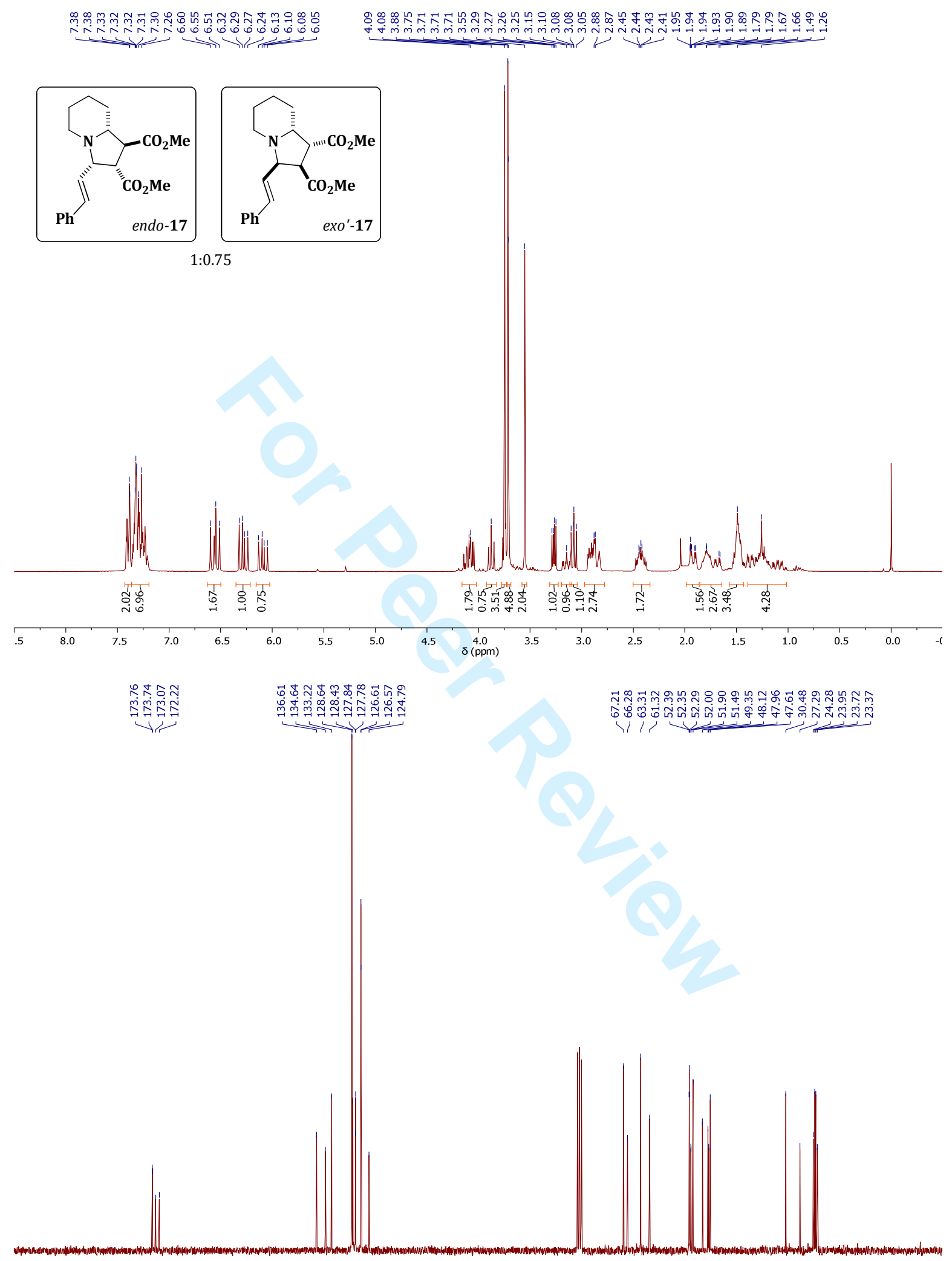

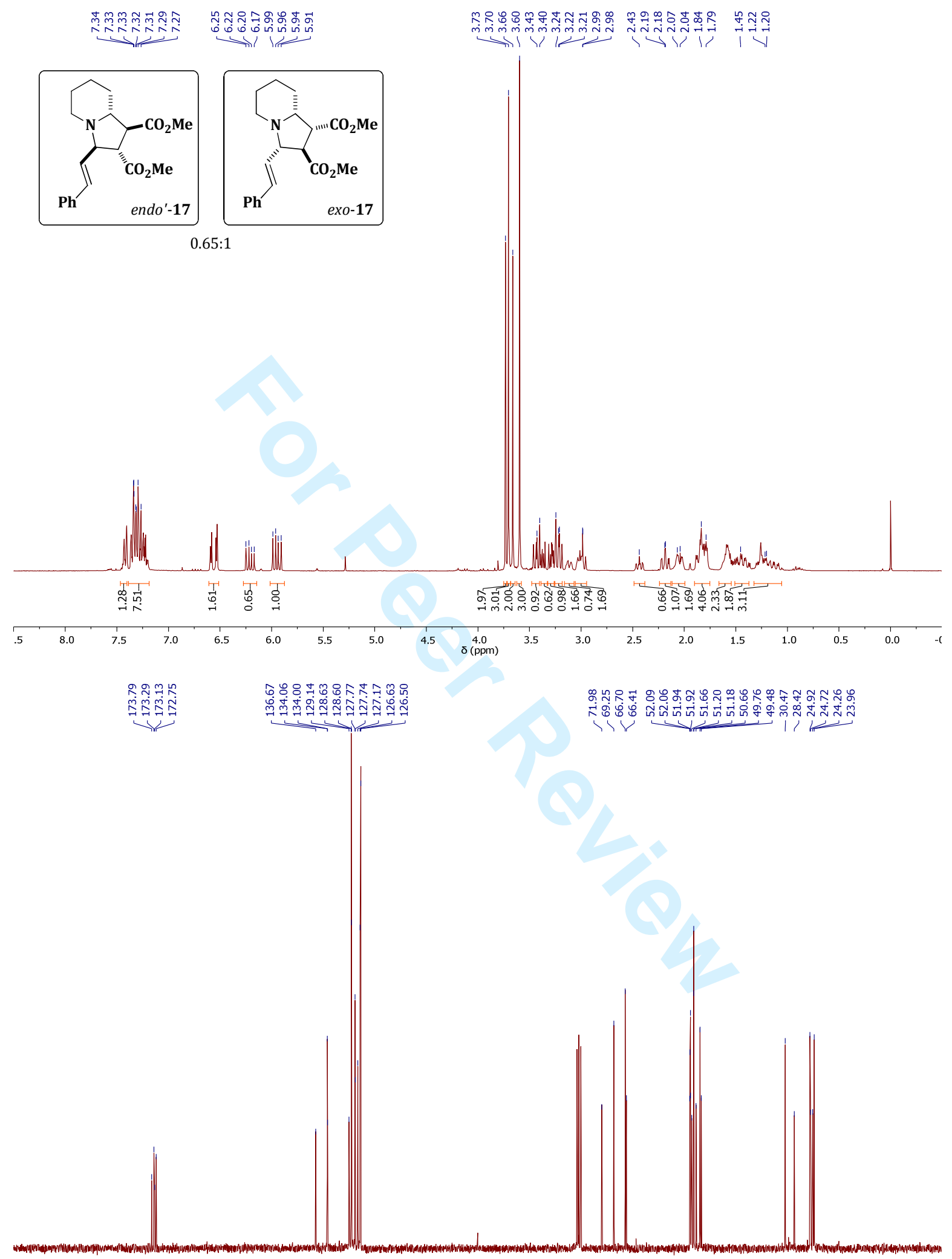

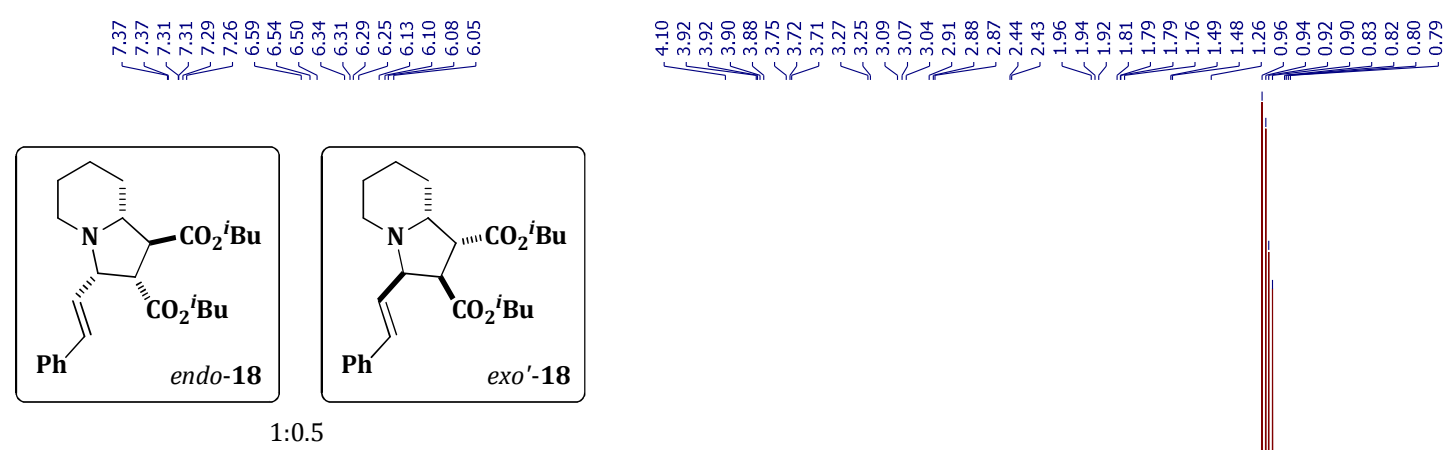

$1: 0.5$
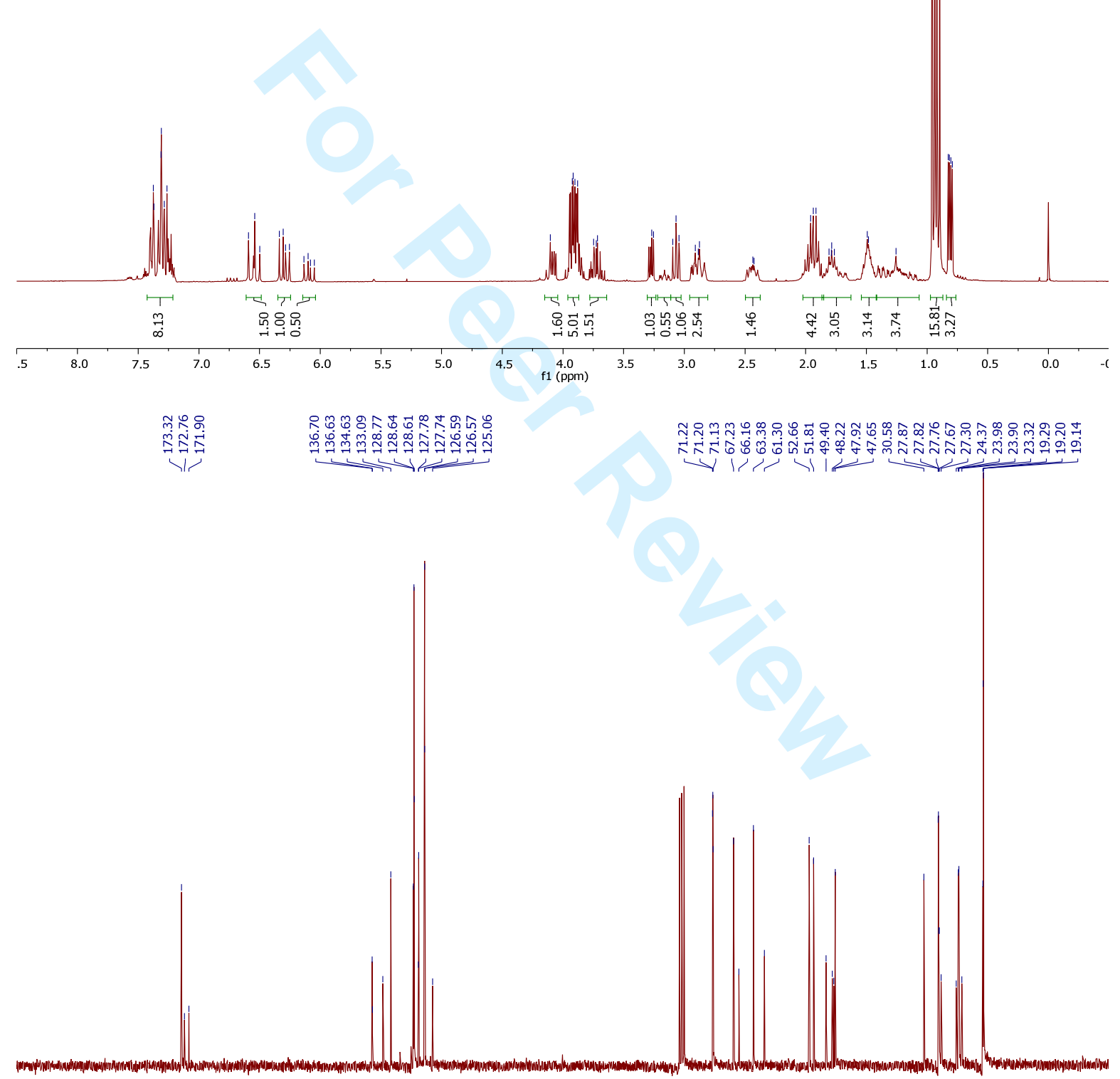

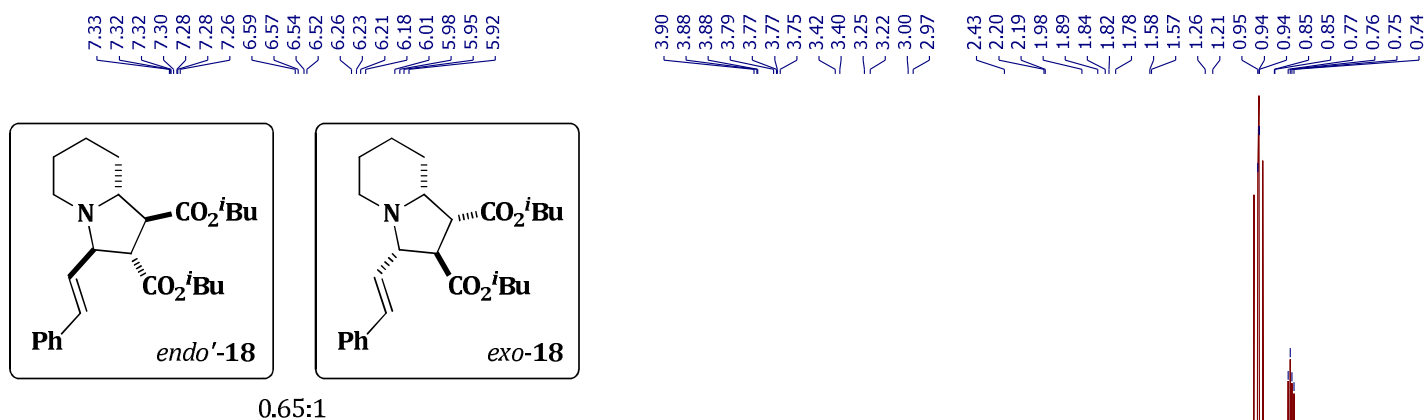

$0.65: 1$
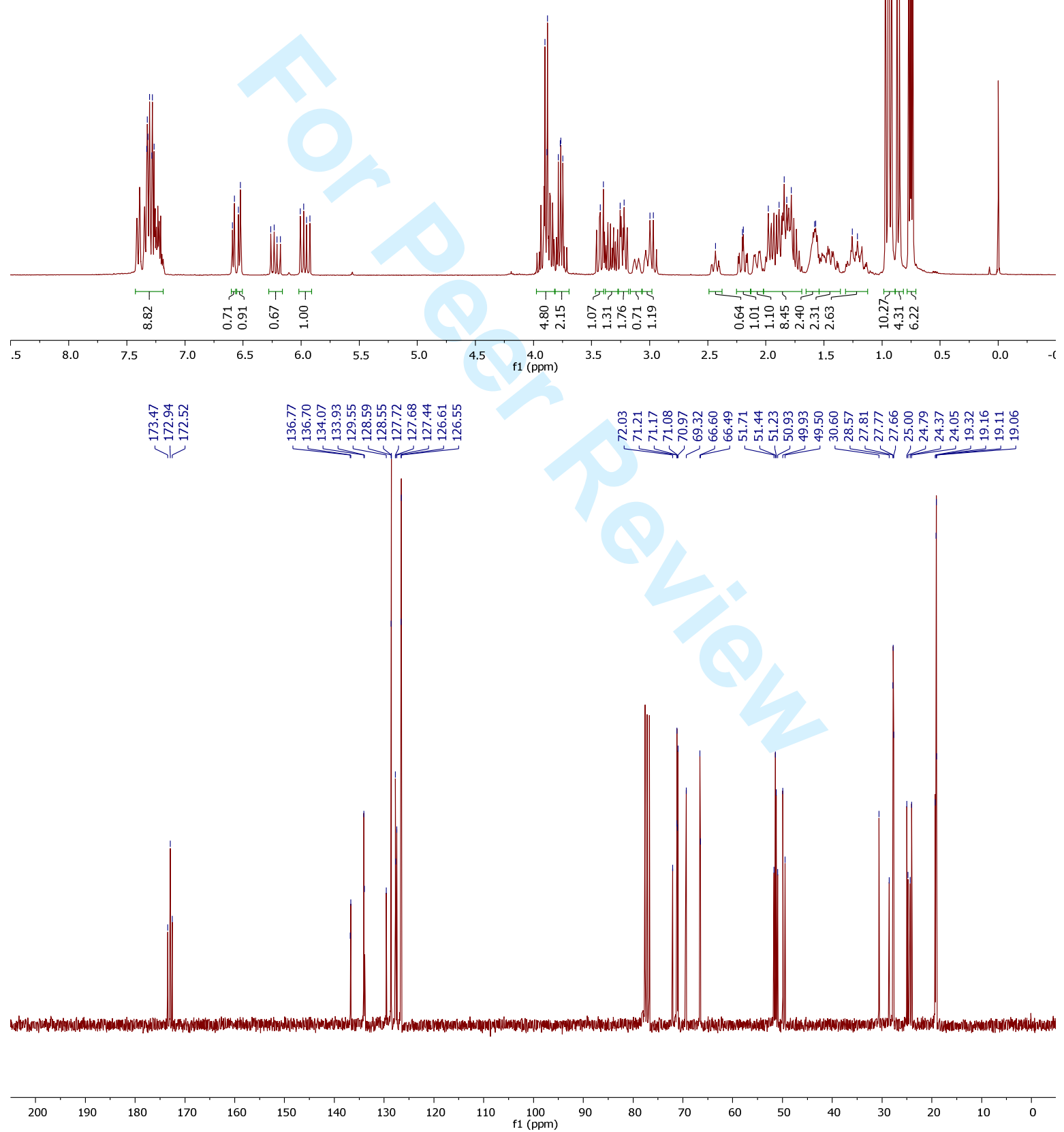

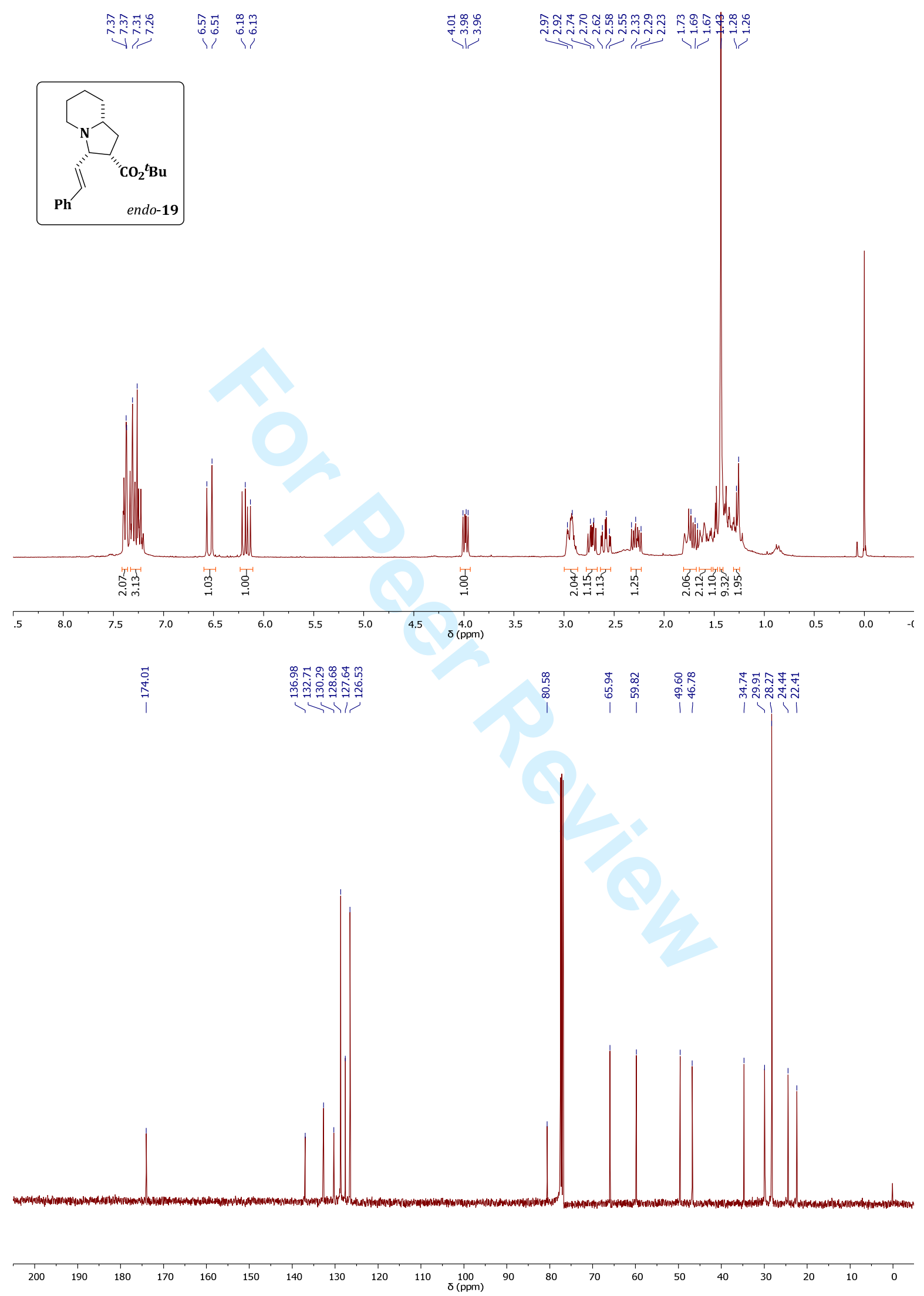

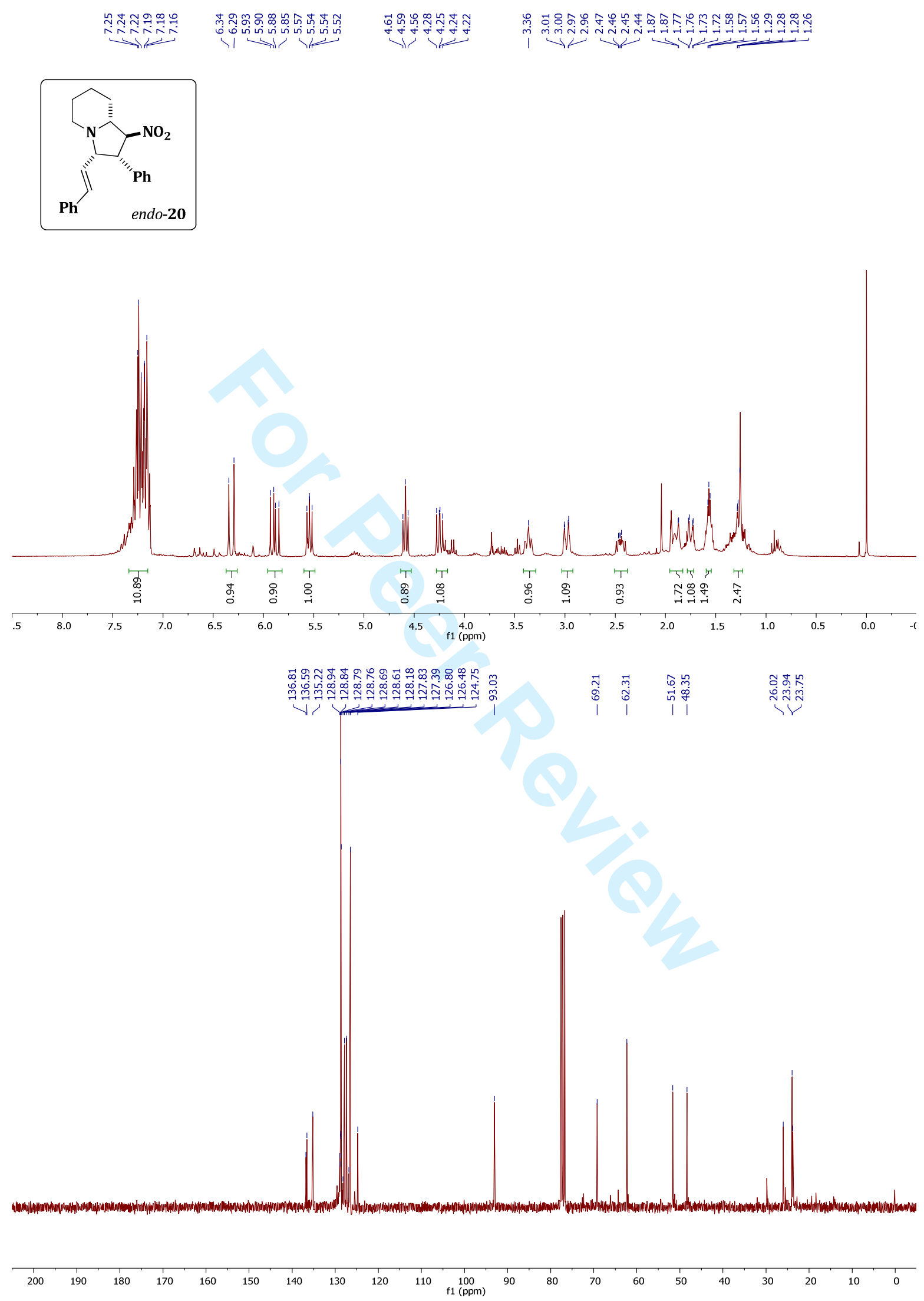

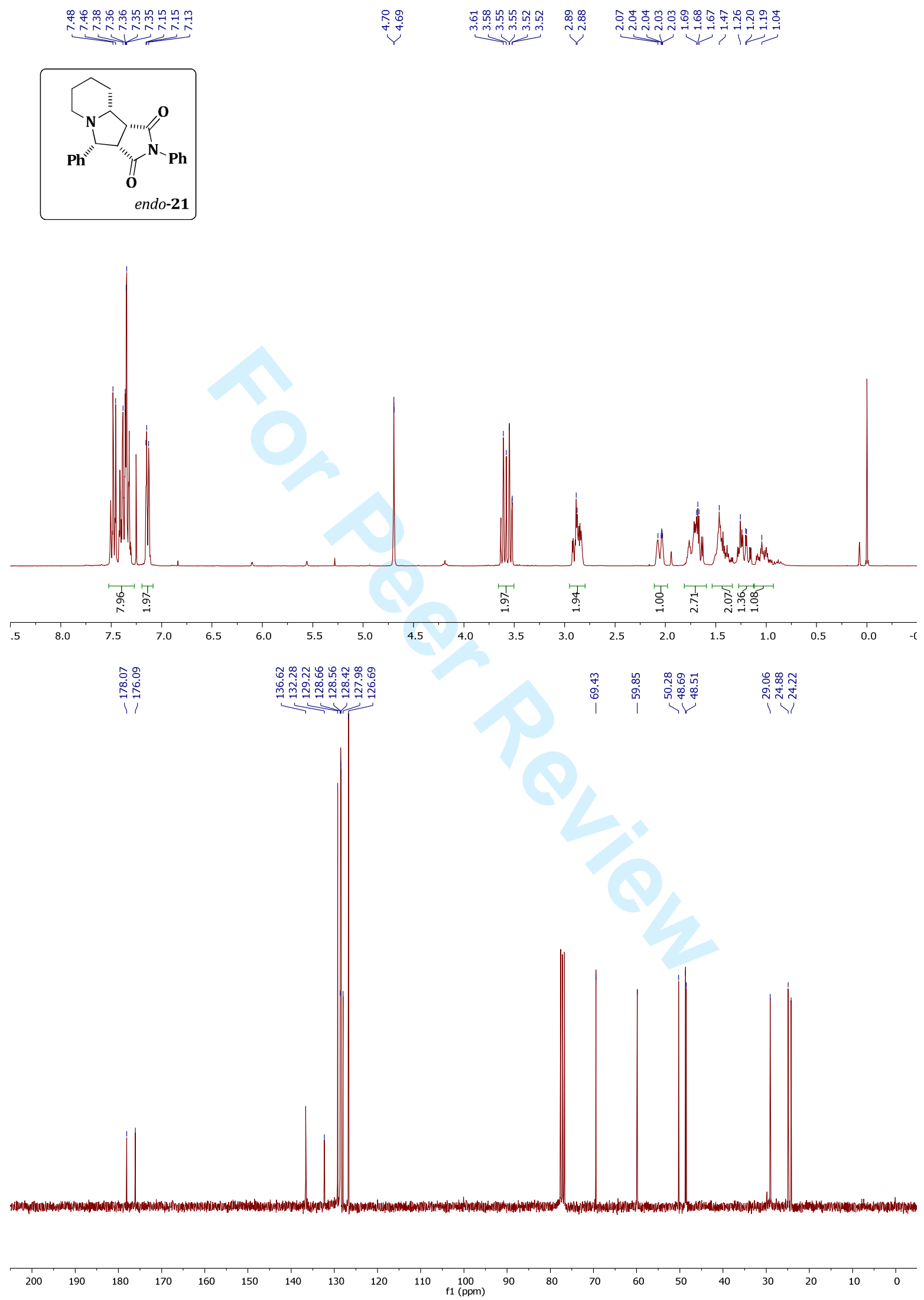

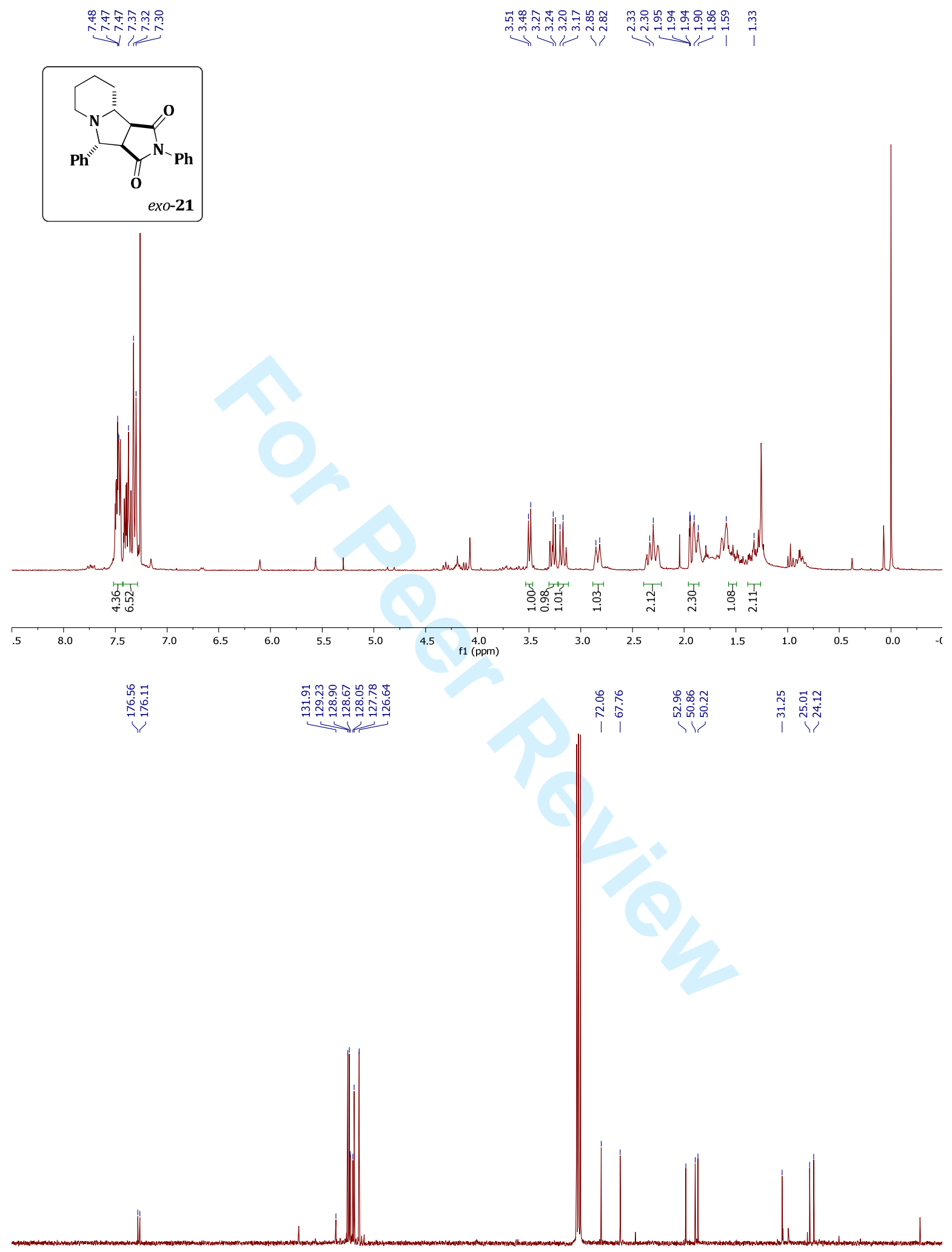
2. X-Ray diffraction analysis of compound endo-13

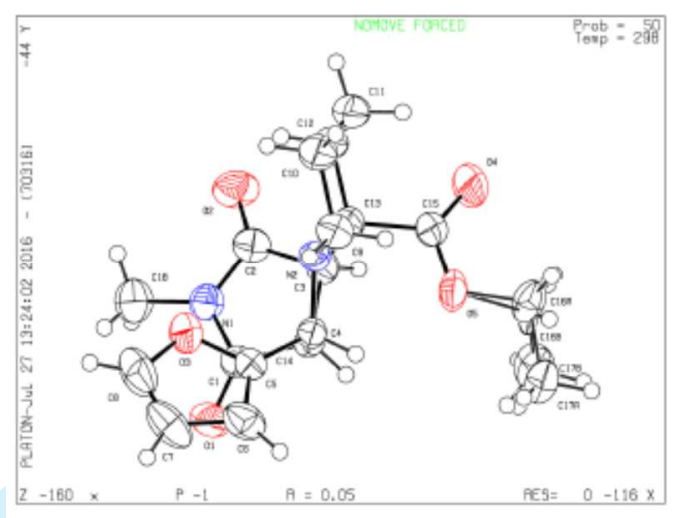




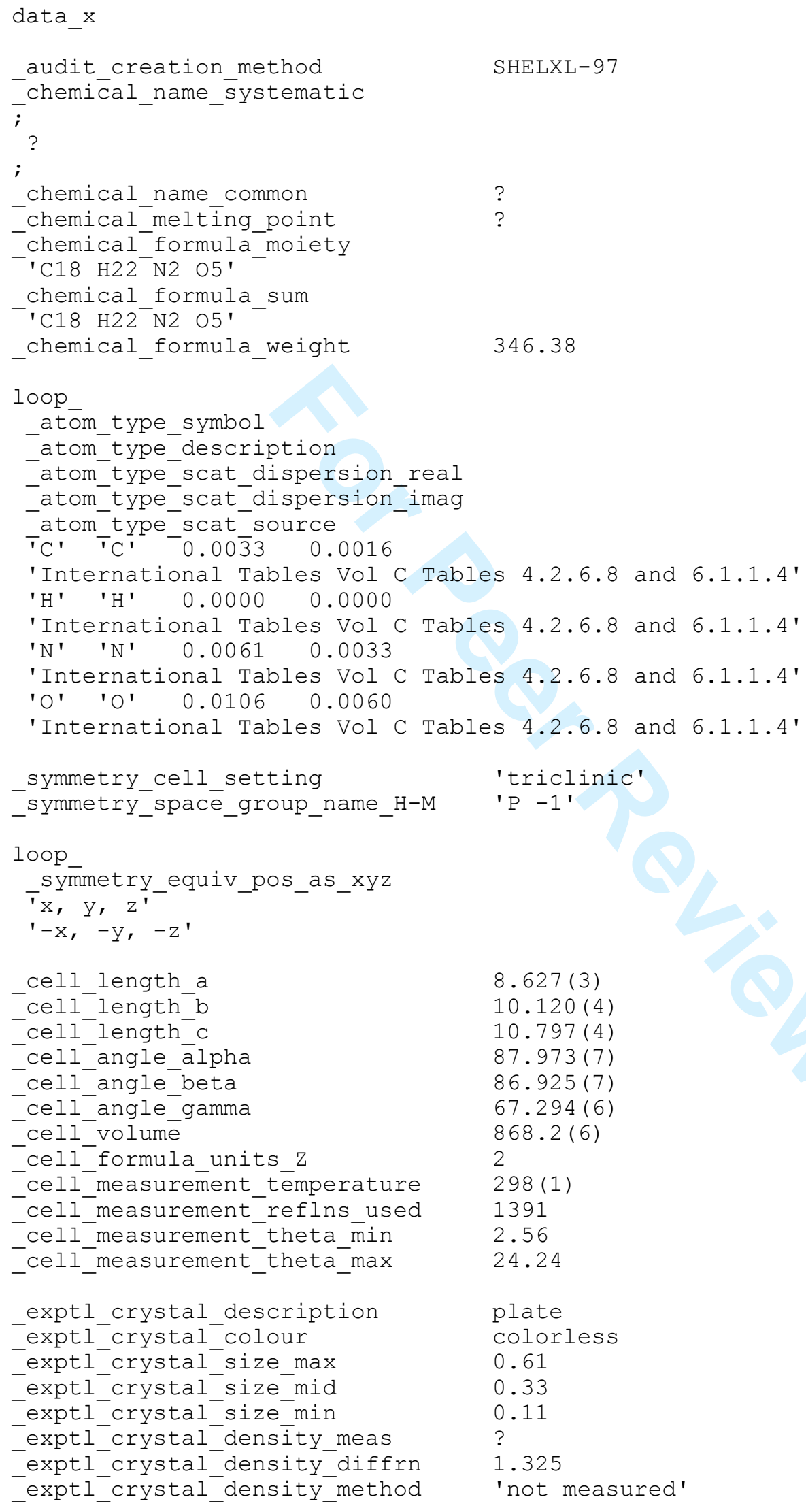




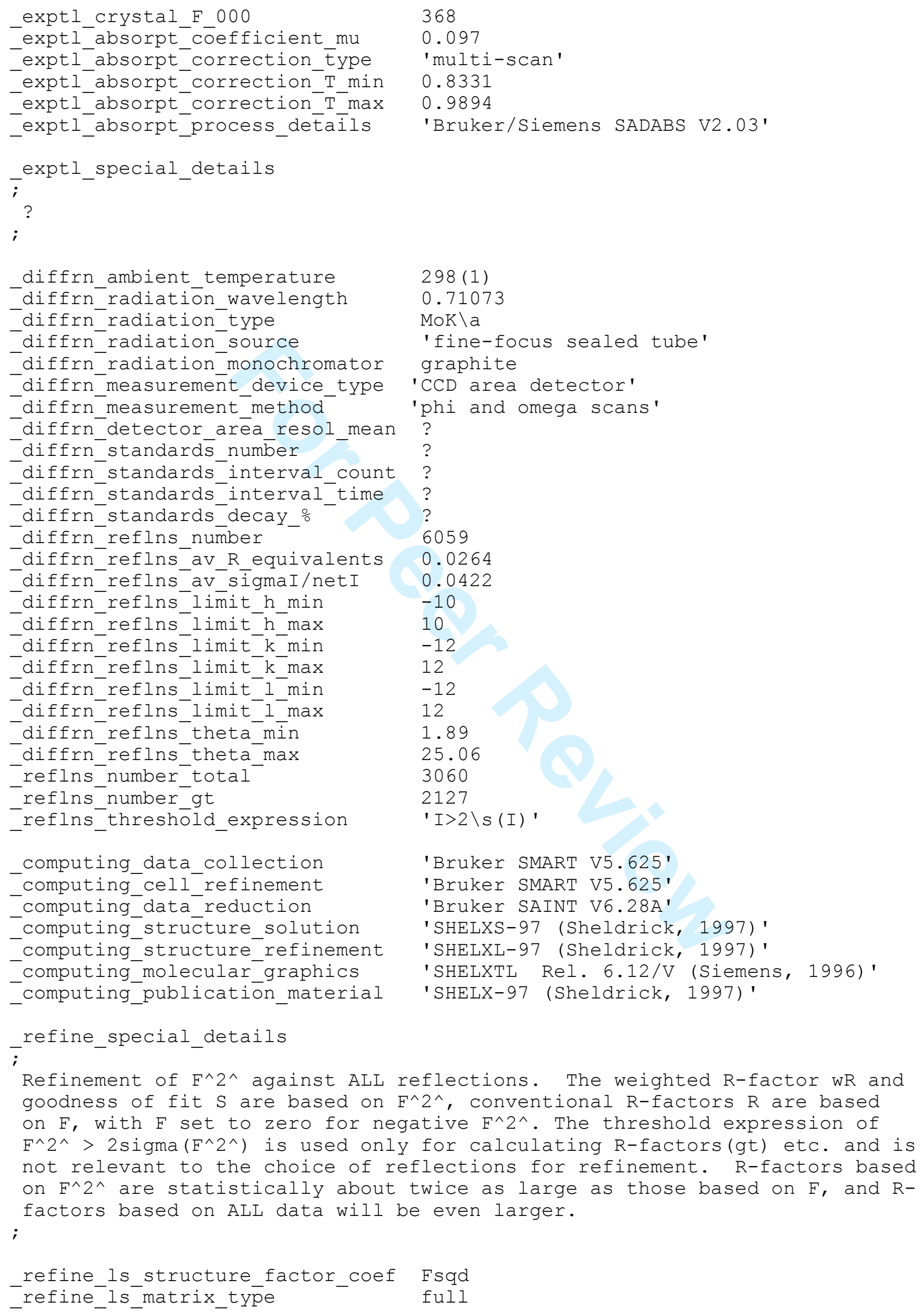




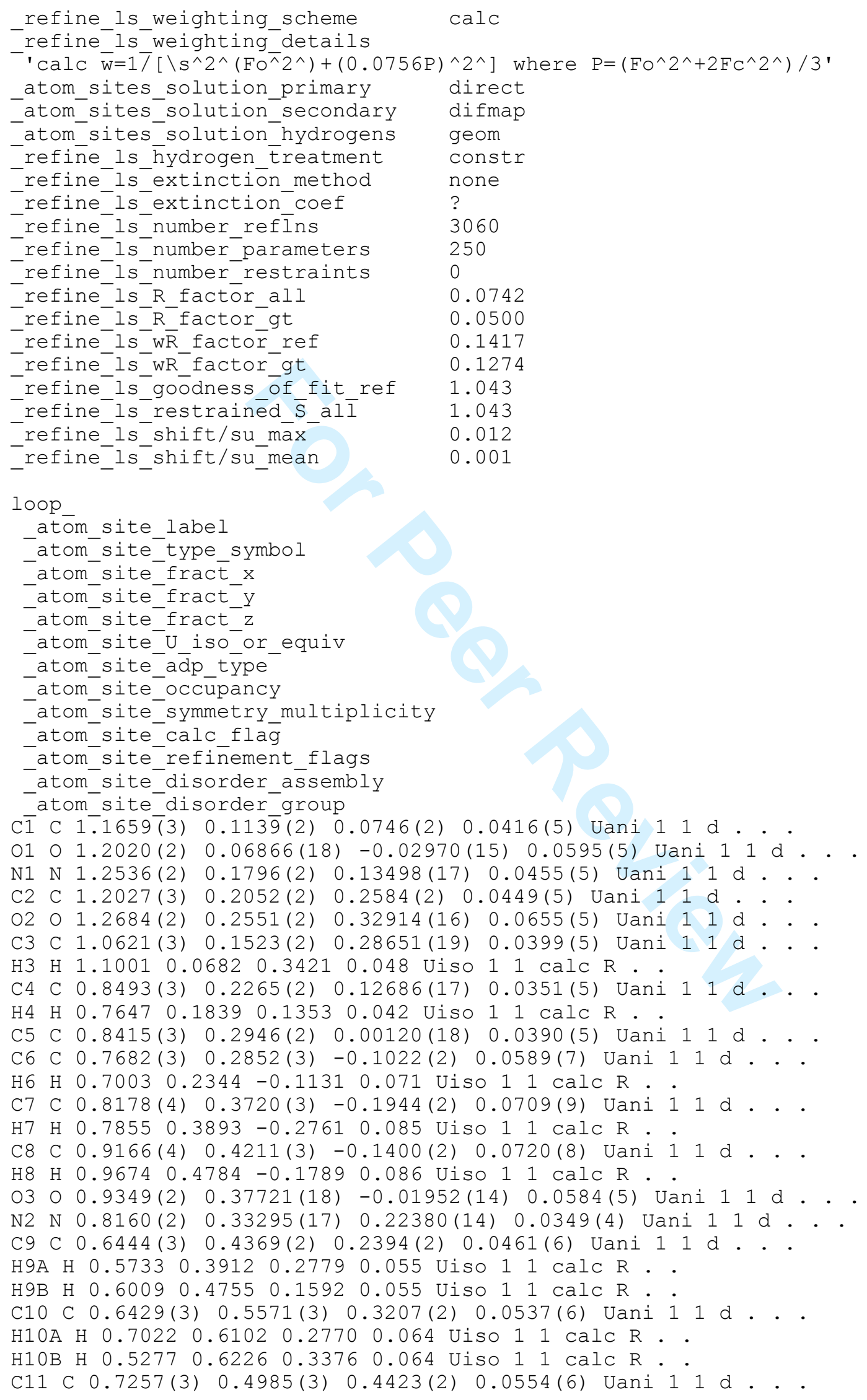


H11A H $0.6570 \quad 0.45780 .49140 .066$ Uiso 11 calc $\mathrm{R}$. . H11B H 0.73260 .57620 .48880 .066 Uiso 11 calc R . C12 C $0.9018(3) \quad 0.3840(2) \quad 0.42078$ (19) 0.0461 (6) Uani 11 d . . H12A H 0.94750 .34270 .49980 .055 Uiso 11 calc R . .

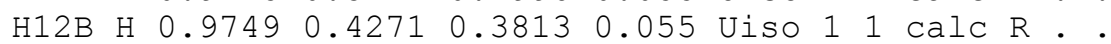
C13 C $0.8956(3) \quad 0.2660(2) \quad 0.33833(17) \quad 0.0366(5) \quad U a n i 11$. . C14 C $1.0236(3) \quad 0.1111(2) 0.15965$ (18) 0.0376 (5) Uani 11 d . . $\mathrm{H} 14 \mathrm{H} 1.0203 \quad 0.01540 .16340 .045$ Uiso 1 calc R . C15 C $0.8081(3) \quad 0.1800(2) \quad 0.4153(2) \quad 0.0461(6)$ Uani 11 d A . $0400.8085(3) \quad 0.1675(2) \quad 0.52540(16) \quad 0.0915(8)$ Uani $11 d$. . $0500.7422(2) \quad 0.1141(2) \quad 0.34412(14) \quad 0.0616(5)$ Uani $11 d$. .

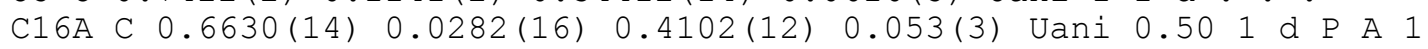
H16A H 0.55420 .08920 .44580 .063 Uiso 0.501 calc PR A 1 $\begin{array}{llllllllllll}\mathrm{H} 16 \mathrm{~B} & \mathrm{H} & 0.7324 & -0.0261 & 0.4767 & 0.063 & \text { Uiso } & 0.50 & 1 & \mathrm{calc} \text { PR A } 1\end{array}$ C17A C $0.6425(9) \quad-0.0733(8) \quad 0.3161(8) \quad 0.067(2)$ Uani 0.501 d P A 1 H17A H $0.5718-0.01830 .25170 .100$ Uiso 0.501 calc PR A 1 H17B H $0.5920-0.13340 .35720 .100$ Uiso 0.501 calc PR A 1 $\mathrm{H} 17 \mathrm{C}$ H $0.7508-0.13180 .28050 .100$ Uiso 0.501 calc PR A 1 C16B C $0.677(2) \quad 0.0070(19) \quad 0.3987(14) \quad 0.096(6)$ Uani 0.501 d P A 2 H16C H $0.6924-0.00030 .48740 .115$ Uiso 0.501 calc PR A 2 H16D H 0.55780 .04030 .38580 .115 Uiso 0.501 calc PR A 2 C17B C $0.7494(15) \quad-0.1134(9) \quad 0.3528(9) \quad 0.109(4)$ Uani 0.501 d P A 2 H17D H $0.7406-0.10590 .26440 .163$ Uiso 0.501 calc PR A 2 H17E H $0.6975-0.17630 .38610 .163$ Uiso 0.501 calc PR A 2 H17F H $0.8659-0.1510 \quad 0.37260 .163$ Uiso 0.501 calc PR A 2 C18 C 1.3891 (3) 0.2141 (3) 0.0750 (3) 0.0680 (8) Uani 11 . . H18A H 1.40620 .28600 .12160 .102 Uiso 1 calc R . . H18B H $1.3597 \quad 0.2494-0.00770 .102$ Uiso 11 calc R . H18C H 1.49070 .12950 .07180 .102 Uiso 11 calc R .

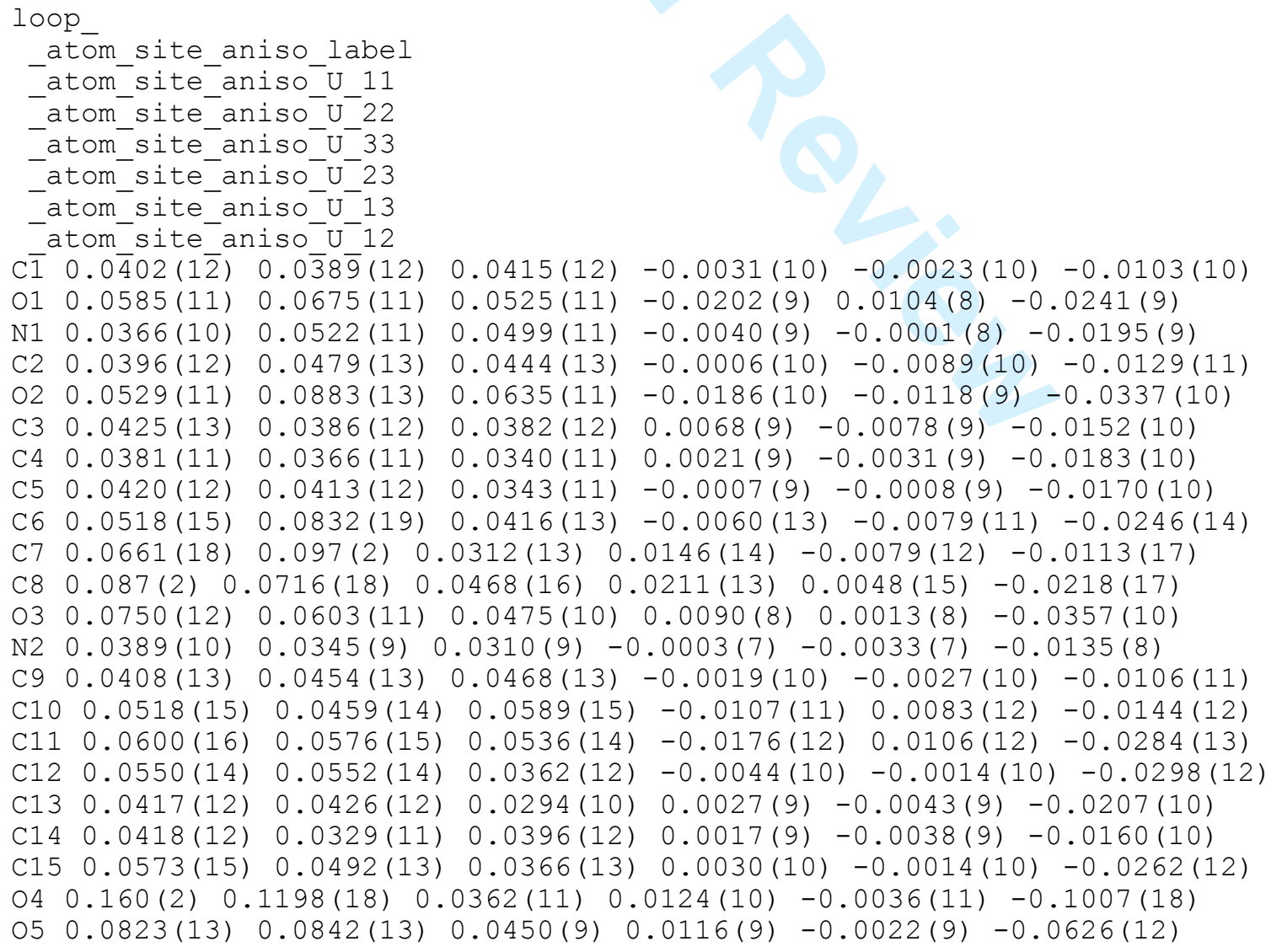




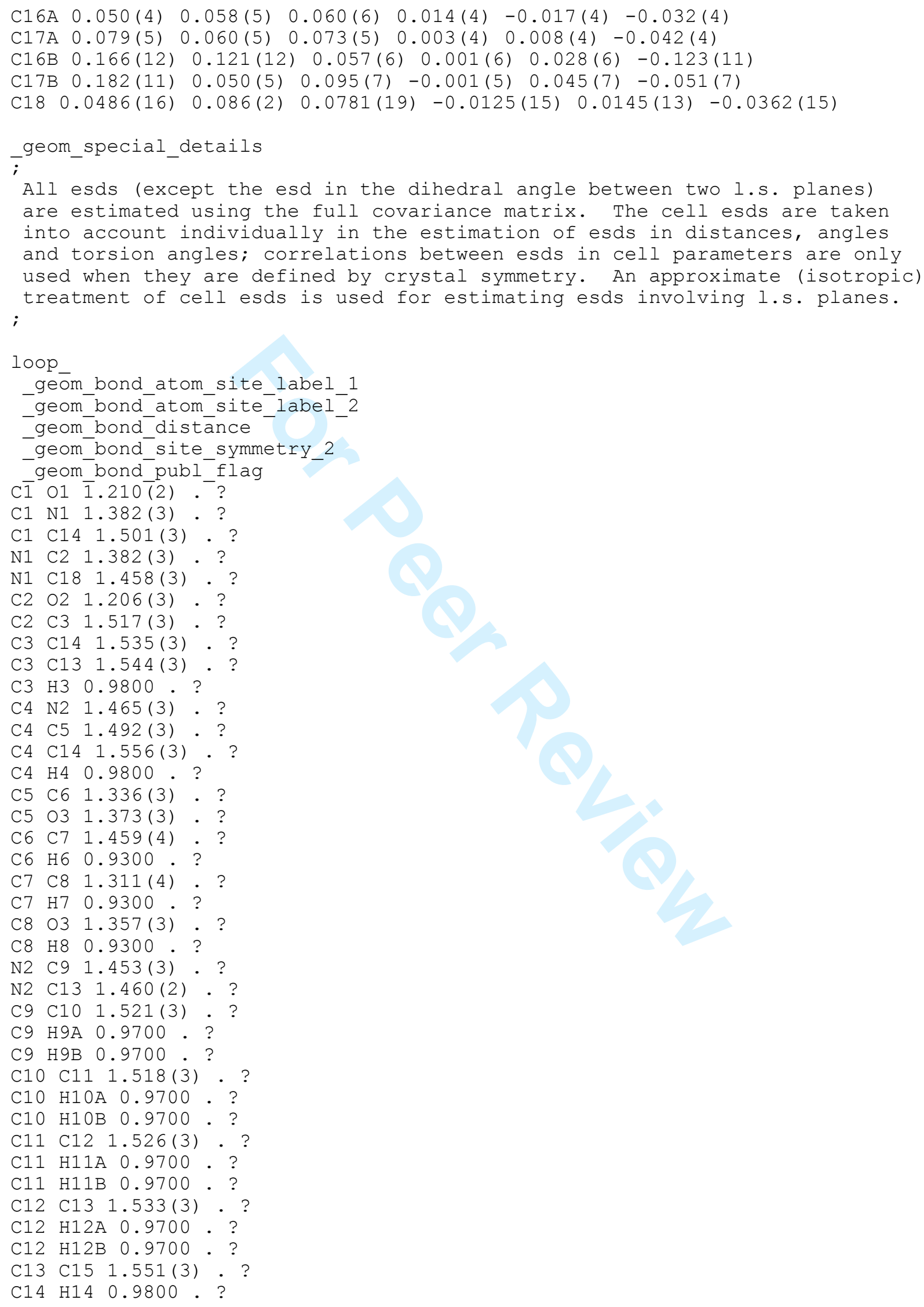




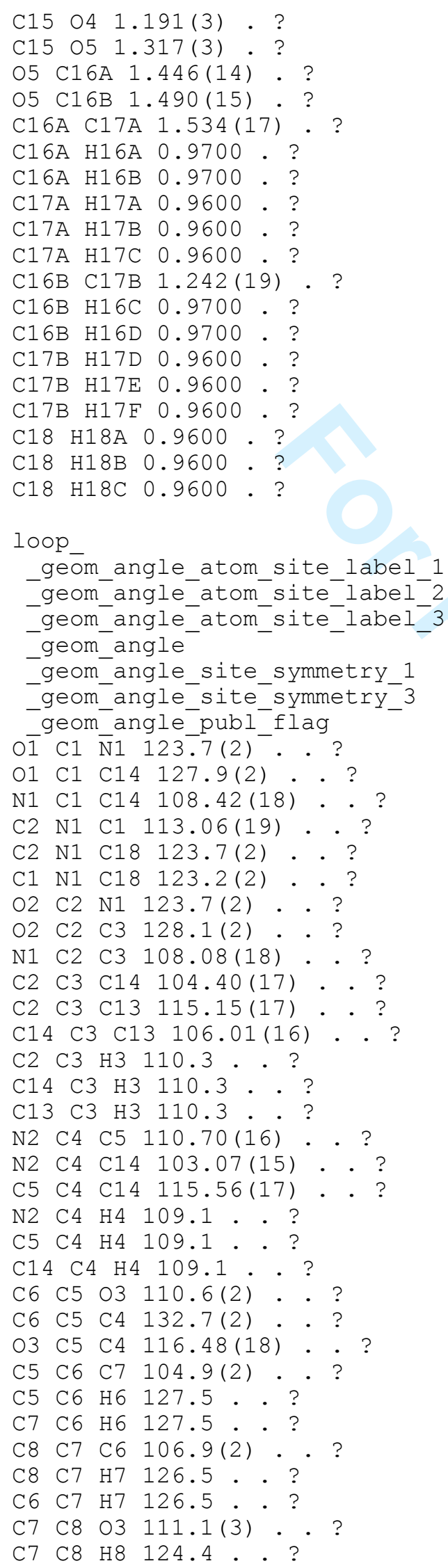




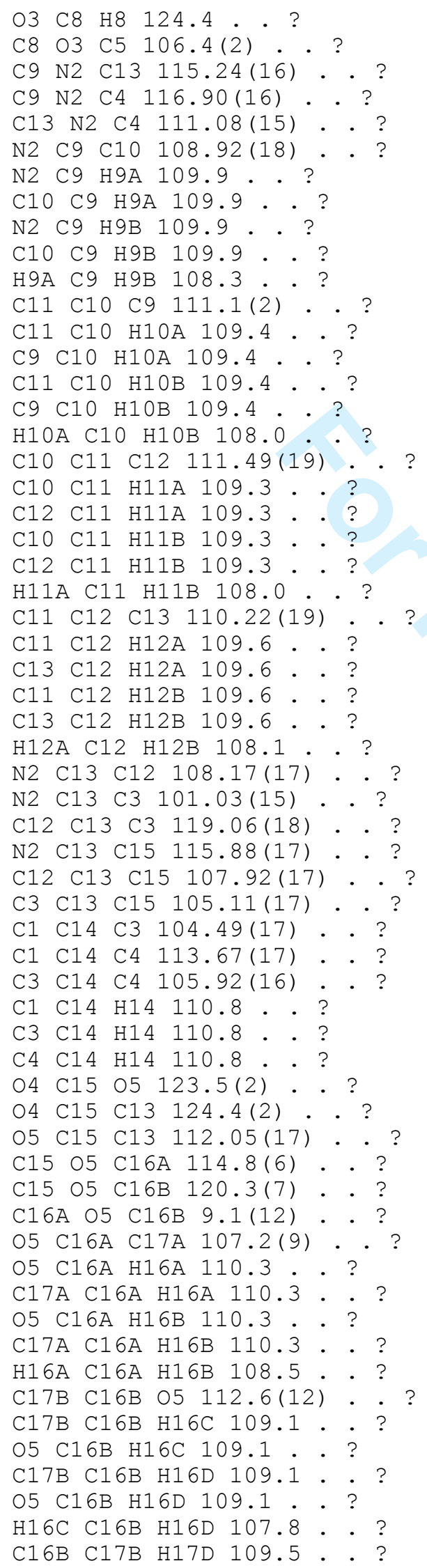




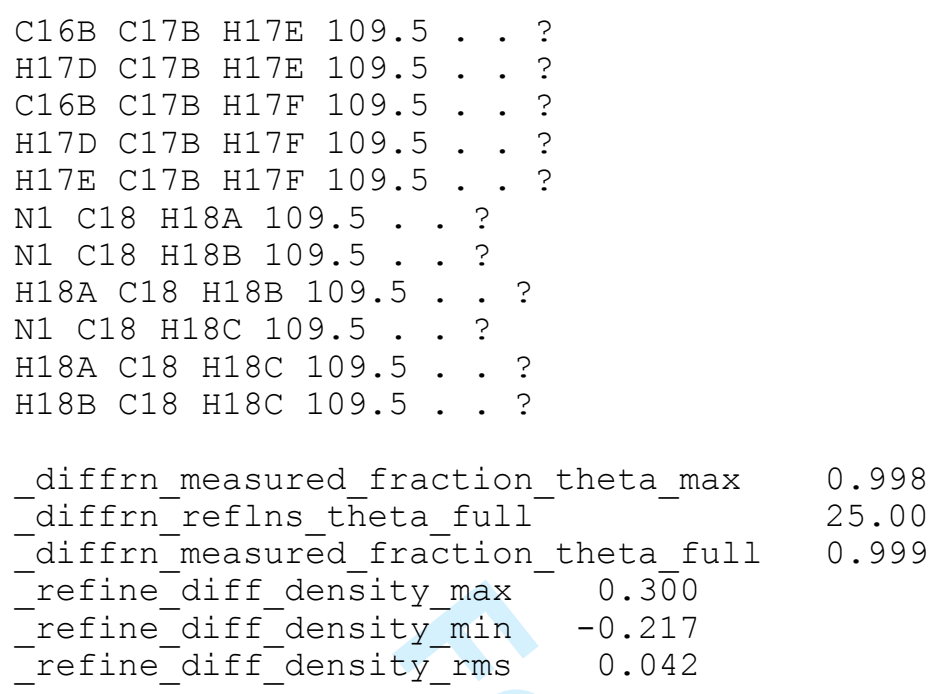




\section{Multicomponent diastereoselective synthesis of indolizidines via 1,3- dipolar cycloadditions of azomethine ylides}

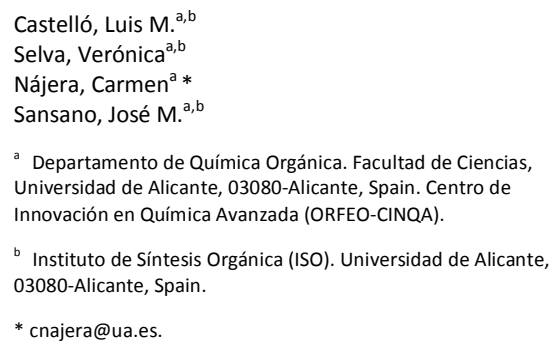

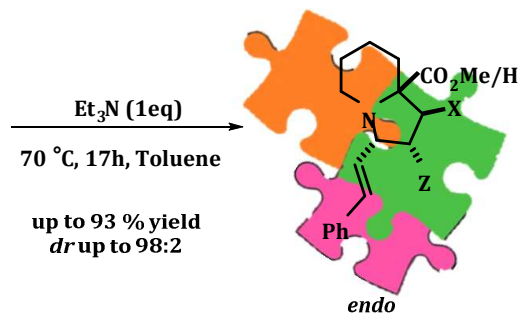

\section{Received:}

Accepted:

Pol:

Abstract The synthesis of polyfunctionalized indolizidines from pipecolinic acid alkyl ester derivatives, aldehydes and a wide range of dipolarophiles by a multicomponent 1,3-dipolar cycloadditions has been developed in a diastereselective manner. Reactions take place in toluene with short reaction times at $70{ }^{\circ} \mathrm{C}$, giving good yields. The synthesis of these fused heterocycles is also studied starting from the pipecolinic acid, generating the dipole through a decarboxylative route at $120{ }^{\circ} \mathrm{C}$. The relative configuration of the resulting products, as well as the mechanistic pathways are also explained.

Key words cycloaddition, multicomponent, indolizidine, azomethine ylides, iminium route, decarboxylative route

\section{Introduction}

The indolizidine structure can be found in many alkaloid families being the most important moiety in the molecule. ${ }^{1}$ These alkaloids, which can be isolated from plant or animal sources, have shown important biological properties and medicinal applications. ${ }^{2}$ As representative examples, pharmaceutically interesting tetrahydroxyalkaloids such as castanospermine and 6-epicastanospermine are possible lead compounds in the search for anti-AIDS drugs, and the most simple structure of tashiromine has multiple interesting biological activities (Figure 1).

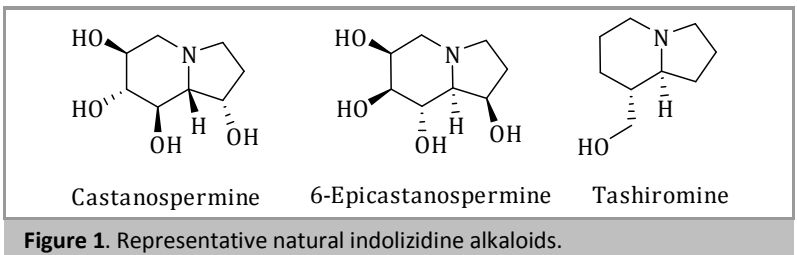

Many synthetic approaches have been successfully developed to prepare this fused heterocyclic skeleton. Most of them can be classified according to the cyclization order, that means, five-member ring followed by six-membered ring construction $(5 \rightarrow 6)$ and vice versa $(6 \rightarrow 5) \cdot{ }^{3}$ The most common used access is the $5 \rightarrow 6$ pathway, and the reason is the high availability of both natural or synthetic polifunctionalized pyrrolidines or proline derivatives. ${ }^{4,5}$ In addition, interesting $6 \rightarrow 5$ sequences have been published. ${ }^{6}$

Such as it has been extensively demonstrated, 1,3-dipolar cycloaddition (1,3-DC) involving azomethine ylides is a potential tool for the construction of complex alkaloid structures. ${ }^{7,89}$ Focusing on $6 \rightarrow 5$ sequences mediated by these type of cycloadditions generating the intermediate azomethine ylides via decarboxylation route, 10 intramolecular 1,3-DC between $\delta$-chloroaldehydes, glycine and electrophilic alkenes, gave indolizidines in very high yields (Scheme 1a). ${ }^{11}$ Another decarboxylations underwent by tetrahydroisoquinoline-3carboxylic acid and by tetrahydro- $\beta$-carboline-3-carboxylic acid also gave polycycles in good yields. ${ }^{12}$

The generation of the azomethine ylide through the iminium route, where a decarboxylation do not occur, has also been explored. ${ }^{13,14,15}$ Ethyl pipecolinate was used as starting material in the generation of the corresponding iminium salt only with benzaldehyde at $120{ }^{\circ} \mathrm{C}$ yielding mixture of stereoisomers when $\mathrm{N}$-methylmaleimide, dimethyl fumarate and maleate were used (Scheme 1b). ${ }^{16}$ In all these examples the chemical yield was almost quantitative (95\%) and the mixture of diastereoisomers was notable. In the case of dimethyl fumarate and $N$-phenylmaleimide (NPM) a 50:50 and a 75:25 mixture of endo:exo adducts was obtained, respectively. The intrinsic thermal isomerization of dimethyl maleate also promoted the generation of a third diastereoisomer (Scheme 1b). 


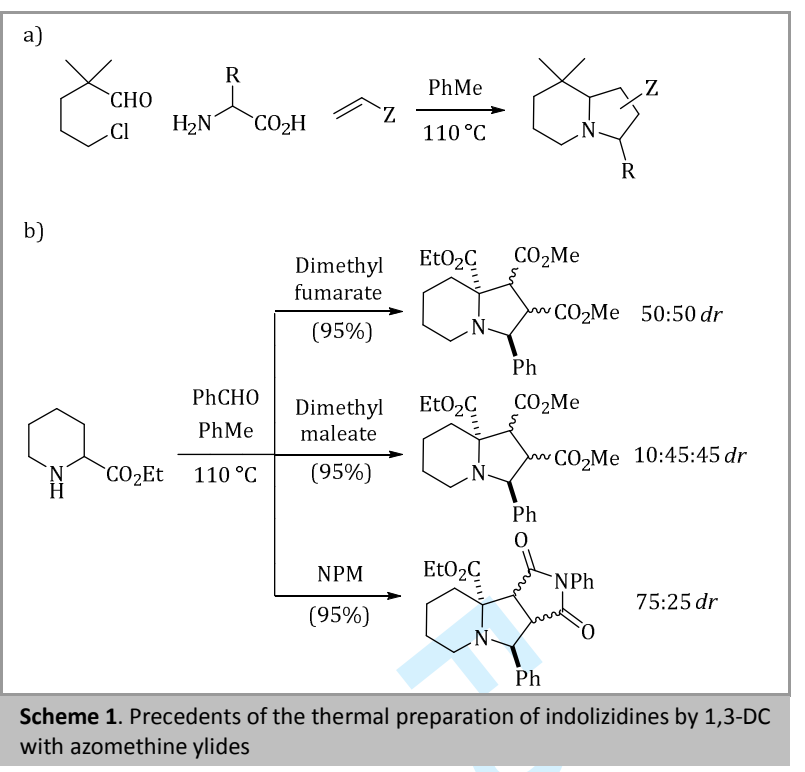

Following with the multicomponent 1,3-dipolar cycloaddition strategy designed for the synthesis of pyrrolizidines ${ }^{17}$ using proline ester hydrochlorides, aldehydes and dipolarophiles, at room temperature, we will survey in this work the general scope of this cycloaddition employing six-membered ring templates for the construction of the fleeting azomethine ylide with aldehydes, and further capture with dipolarophiles. We will study the generation of these intermediates through the iminium route, or through the decarboxylation way. All these reactions will be designed with the idea of increasing the functionality of the resulting polysubstituted indolizidines improving the diastereomeric ratio at the end of the processes. A comparison between both methodologies will be also stablished.

\section{Results and discussion}

Following the optimized reaction conditions described by our group in the synthesis of pyrrolizidines, ${ }^{17 a, c}$ the first attempt to run 1,3-DC between the iminium salt, generated from methyl pipecolinate hydrochloride $\mathbf{1 a}$ and cinnamaldehyde, and further cyclization with $\mathrm{N}$-substituded maleimides as dipolarophiles was performed at $25^{\circ} \mathrm{C}$ in toluene. The reaction did not take place neither using these reaction conditions nor employing the silver catalyzed-process at room temperature. When increasing the temperature to $70{ }^{\circ} \mathrm{C}$ in toluene and in the absence of silver salts the reaction succeeded. Indolizidines 2 and $\mathbf{3}$ were isolated with high endo-diastereoselectivity when methyl pipecolinate and one equivalent of triethylamine were allowed to react with $\mathrm{N}$-methylmaleimide (NMM) or with $\mathrm{N}$ phenylmaleimide (NPM). No differences were observed concerning both of the yield the diastereoselectivity $(70: 30 \mathrm{dr}$ ). Compound 2 was isolated in 81\% overall yield (endo-2 59\%, and exo-2 22\%) and 3 in 75\% overall yield (endo-3 55\%, and exo-3 20\%) (Scheme 2). In contrast, when maleic anhydride was tested higher yield and complete endo-diastereoselectivity was achieved for compound 4 (Figure 2).
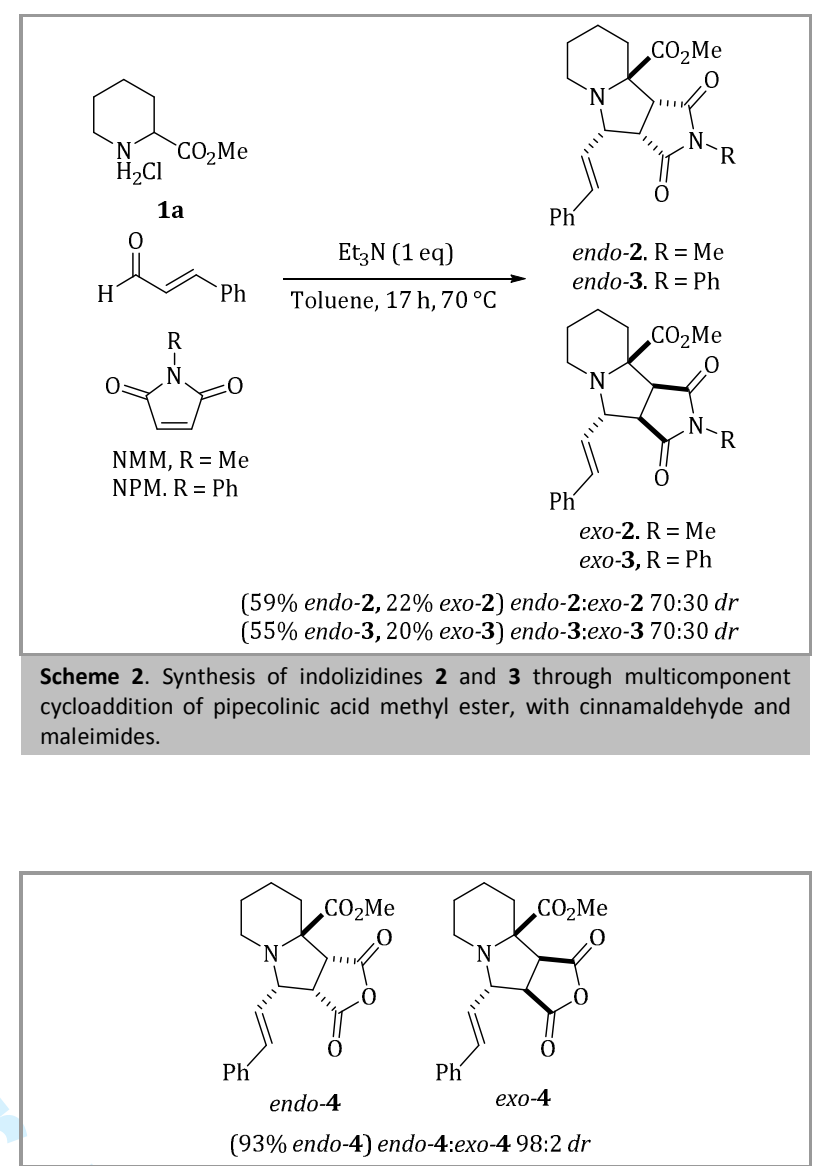

Figure 2. Chemical yield and distereoselection of the reaction of the Scheme 2 using maleic anhydride as dipolarophile.

Following with the study of the general scope several dipolarophiles maintaining the aldehyde structure were tested. The highest endo-diastereselection was achieved when the less sterically hindered methyl acrylate was employed as dipolarophile (Scheme 3) yielding endo-5 (57\%) in a 95:5 $d r$. When methyl fumarate was used as dipolarophile, the diastereoselectivity observed for compound endo-6 (84:16 dr) was slightly lower than the obtained one for the methyl acrylate but higher than with NMM (Scheme 3). trans- $\beta$ Nitrostyrene and chalcone were suitable dipolarophiles for this thermal multicomponent reaction affording indolizidines 7, 8 and $\mathbf{9}$, respectively. With the conjugated ketone the chemical yield was lower ( $66 \%$ overall yield) than the analogous obtained in the example run with the nitroalkene $(72 \%$ overall yield). However, apart from the endo-7 cycloadduct $(17 \%$ yield), the regioisomer exo-8 (55\% yield) was also identified in high proportions. In the case of chalcone the unexpected cycloadduct exo-9 was obtained as major product $(75: 25 \mathrm{dr})$ (Scheme 3).

Methyl 1,2,3,4-tetrahydroisoquinoline-3-carboxylate 10, prepared from phenyl alanine methyl ester ${ }^{18}$ was also tested in this multicomponent process. Cinnamaldehyde, 10 and NPM were mixed and the reaction was warmed at $70{ }^{\circ} \mathrm{C}$ for $17 \mathrm{~h}$. Tetracyclic complex skeleton endo-11 was obtained as major compound in 65\% yield, and exo-11 in $11 \%$ yield with a 86:14 $d r$ (Scheme 4). 


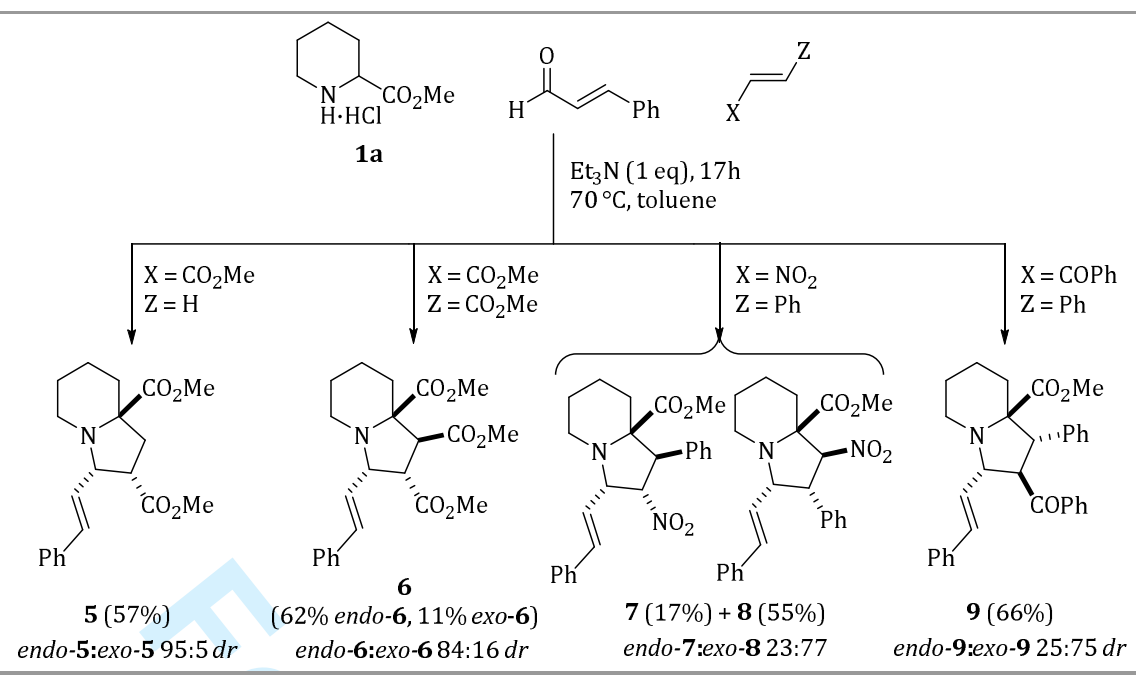

Scheme 3. Multicomponent cycloaddition of pipecolinic acid methyl ester hydrochloride 1a, cinnamaldehyde and different dipolarophiles.

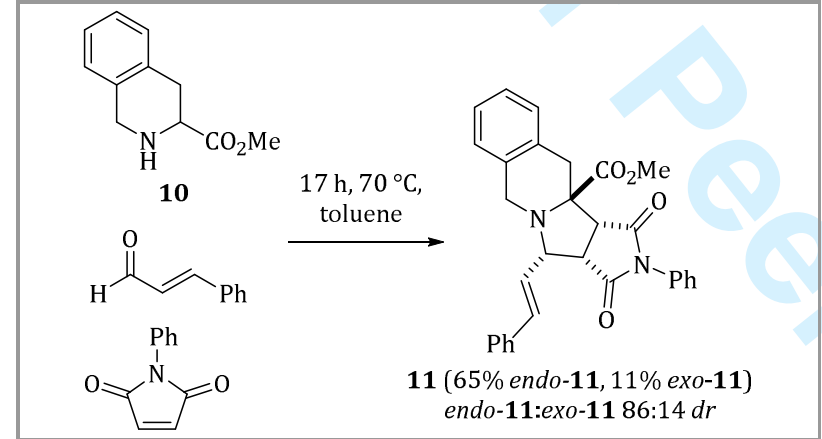

Scheme 4. Synthesis of indolizidine 11 through the multicomponent cycloaddition of 10 and cinnamaldehyde, with NPM.

A comparison with the thermal 1,3-DC reported in the literature by Joucla and coworkers (Scheme 1b), ${ }^{16}$ where benzaldehyde was employed, was done. The reaction with $N$-methylmaleimide did not work under our reaction conditions, and a complex mixture of inseparable products was detected after performing the reaction at $110{ }^{\circ} \mathrm{C}$. However, the reaction involving maleic anhydride, benzaldehyde, and $\mathbf{1 a}$ at $70{ }^{\circ} \mathrm{C}$ gave a modest isolated chemical yield (27\%) of cycloadduct endo-12 as unique diastereoisomer (Scheme 5). Furfural was also tested together with ethyl pipecolinate $\mathbf{1 b}$ and NMM affording endo-cycloadduct 13 as major compound in $82: 18 d r$ and $48 \%$ overall yield (Scheme 5).

Nevertheless, crotonaldehyde, isovaleraldehyde and $(2 E, 4 E)$ hexa-2,4-dienal showed very poor reactivity. According to our studies, reactions run with all type of aldehydes, but specially unsaturated aldehydes, were very sensitive to high temperatures $\left(>70{ }^{\circ} \mathrm{C}\right)$ affording decomposition products (detected in crude ${ }^{1} \mathrm{H}-\mathrm{NMR}$ spectra).

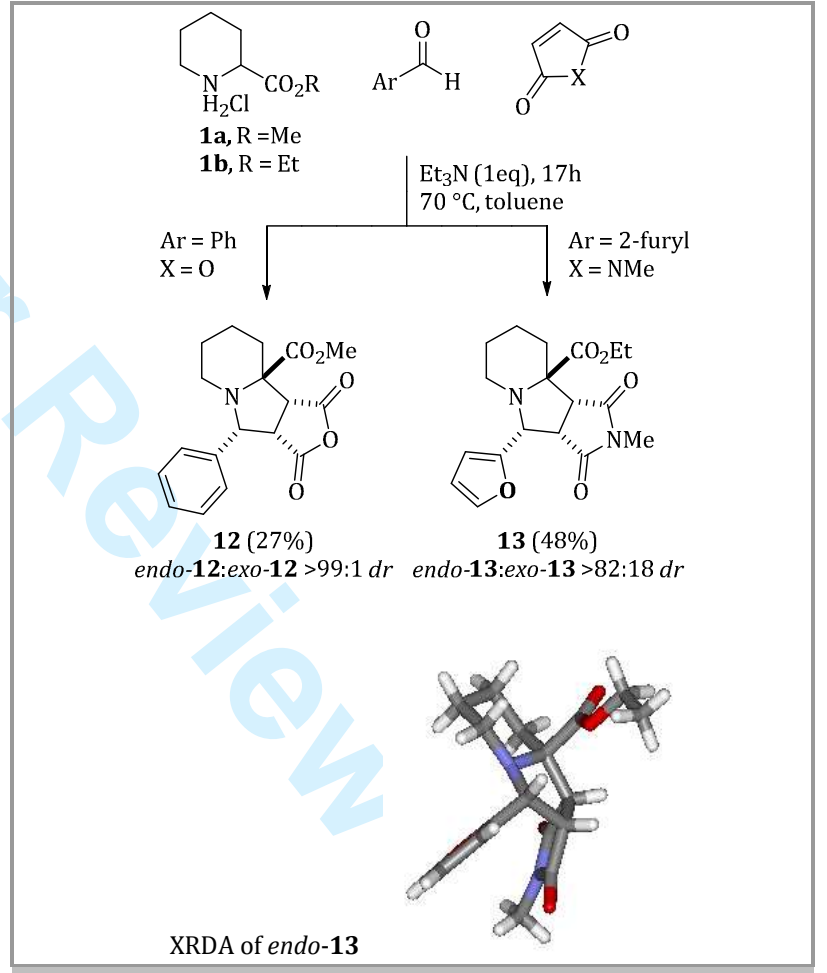

Scheme 5. Synthesis of indolizidines endo-12 and endo-13 through multicomponent cycloaddition of pipecolinic acid alkyl esters 1, with aromatic aldehydes and different dipolarophiles.

After careful analysis of ${ }^{1} \mathrm{H}-\mathrm{NMR}$ of the reaction crudes, only a mixture of two diastereoisomers was identified. At this point, we can assume that the reaction mechanism proceeds with relative high to excellent diastereocontrol as consequence of the S-type dipole generated by iminium route which attacks preferentially by its $\alpha$-position to carbon atom of dipolarophile with partial positive charge (Figure 3a). This S-dipole, through the most favorable endo-approach allows the 2,4-trans-2,5-trans arrangement of the five-membered ring (Figure $3 \mathrm{~b}$ ). This 
preferential trend was observed in compounds $2,3,4,5,6,11$, 12 and 13. Only in the example run with the chalcone the exodiasteroselectivity was preferentially observed presumably due to the high steric interaction between the phenyl group closer to ketone group and the substituents of the cyclic dipole. ${ }^{19}$ In this example a 2,4-cis-2,5-trans arrangement was generated. On the other hand, the cycloadduct resulting from the $\gamma$-attack of the Sdipole was preferred in the reaction performed with trans- $\beta$ nitrostyrene, which is an excellent Michael acceptor able to trap whatever type of resonance forms. In this case, the new compound $\mathbf{8}$ was formed by a more feasible exo-attack of the dipolarophile. This identical behavior was described during the multicomponent synthesis of pyrrolizidines because of steroelectronic effects of the nitroalkene. ${ }^{17}$

The relative configuration of the major endo-cycoadducts 2-6 and 11-13 was proposed according to unambiguous nOe experiments. A representative example of these analyses is shown in Figure 4. The most stable conformations of endo-5 and endo-6 have been represented with the corresponding nOe effects detected. It is noteworthy to indicate that a small, but definitive, increment of electronic population in the signal of methyl group was produced when the hydrogen atom bonded to the C3 position was irradiated. In addition, this configuration was identical to the obtained by Joucla et al. after X-ray diffraction analysis, ${ }^{16}$ and also with the same structural arrangement of pyrrolicidines obtained after multicomponent 1,3-DC involving prolinates. ${ }^{17}$ At the end of the experimental work an X-ray diffraction analysis of crystalline major diastereoisomer endo-1320 could be performed confirming all these stereochemical results obtained by NMR experiments (Scheme 5).

a)

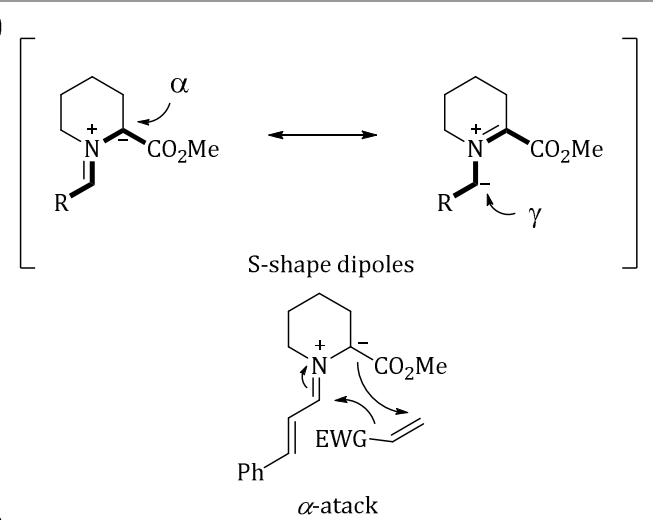

b) endo-approach exo-approach
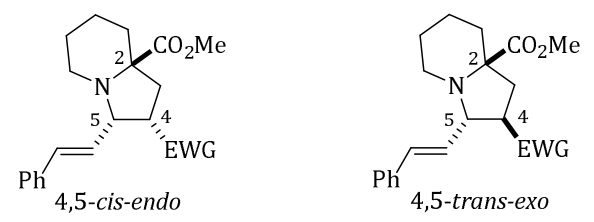

Figure 3. Mechanistic details of the synthesis of indolizidines by the iminium route.

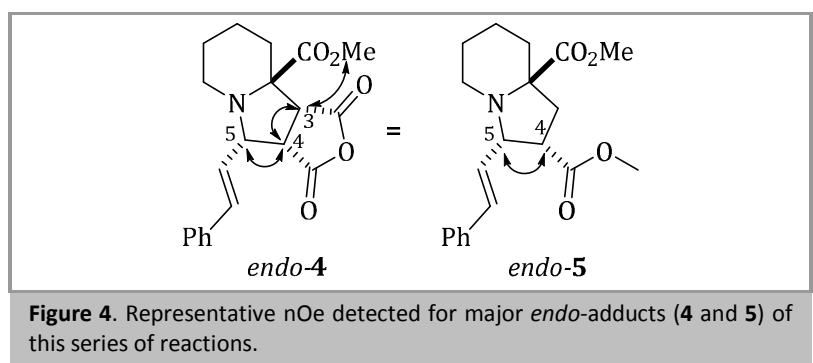

Next, we study the availability of performing the corresponding 1,3-DC starting from pipecolinic acid 14, aldehydes and dipolarophiles. In this reaction, the necessary decarboxylation of the iminium salt generated in situ occurred at higher temperatures (refluxing toluene) (Scheme 6). To the best of our knowledge, this type of cycloaddition of $\mathbf{1 4}$ has not been reported yet. ${ }^{21}$ Thus, compound 14, cinnamaldehyde, and NMM were diluted in toluene and the mixture was heated in a sealed tube at $120{ }^{\circ} \mathrm{C}$ (bath temperature) obtaining a mixture of four different stereosiomers $\mathbf{1 5}$ in 89\% overall yield (Table 1, entry 1). In all cases the diastereomeric ratio observed in the crude ${ }^{1} \mathrm{H}$-NMR spectra was identical to the analogous one determined after separation of each isomers by column chromatography. With NPM chemical yield of $\mathbf{1 6}$ was lower (78\%) but the endodiastereoselection was the highest of all this series of decarboxylative reactions using cinnamaldehyde (Table 1, entry 2). Dimethyl and diisobutyl fumarates gave both identical chemical yields (75\%) and mixtures of diastereoisomers of products 17 and 18 (Table 1, entries 3 and 4). Non-symmetrical dipolarophiles such as tert-butyl acrylate and trans- $\beta$ nitrostyrene were next evaluated. Compounds $\mathbf{1 9}$ and $\mathbf{2 0}$ were isolated in 52 and $40 \%$ overall yields, respectively (Table 1, entries 5 and 6). Finally, benzaldehyde was tested with $\mathbf{1 4}$ and NPM affording a very high yield (95\%) of compound 21 as mixture of four stereoisomers (Table 1, entry 7). However, the reaction with NMM or tert-butyl acrylate only afforded decomposition products at the end of the reaction. Other aldehydes such as crotonaldehyde, isovaleraldehyde and furfural also failed as starting materials in the multicomponent reaction employing NMM.

After careful analyses of selective nOe experiments of each isolated product/mixture, and by comparison of the analogous chemical shifts and coupling constants we could identify each structure. Endo-cycloadduct was always the most abundant stereoisomer, followed by the exo-adduct and a couple of similar diastereoisomers with different olefinic chemical shifts. nOe experiments revealed clear all-cis-arrangement in C2, C3, C4, and C5, for the endo-cycloadduct 15 (Figure 5). Apart from cismaleimide ring junction nOe, a very small one was observed between hydrogens bonded to $\mathrm{C} 2$ and $\mathrm{C} 5$ positions (Figure 5). A crucial nOe between hydrogens placed at $\mathrm{C} 2$ and the closer olefinic one was observed in both endo'- and exo'-15 (Figure 5).

With all these stereochemical information, we can propose that the reaction, once produced the decarboxylation, operated through the most stable S-shape dipole interacting with the electrophilic alkene by its $\alpha$-position. S-Shape dipole underwent thermal steromutation in the iminium salt affording unstable Ushape dipole, which is the responsible of the generation of 
endo'- and exo'-diastereoisomers. Besides, the regioselectivity of this cycloaddition was very high because we could not detect any stereoisomer due to the attack of the dipole by its $\gamma$-position (Figure 6).

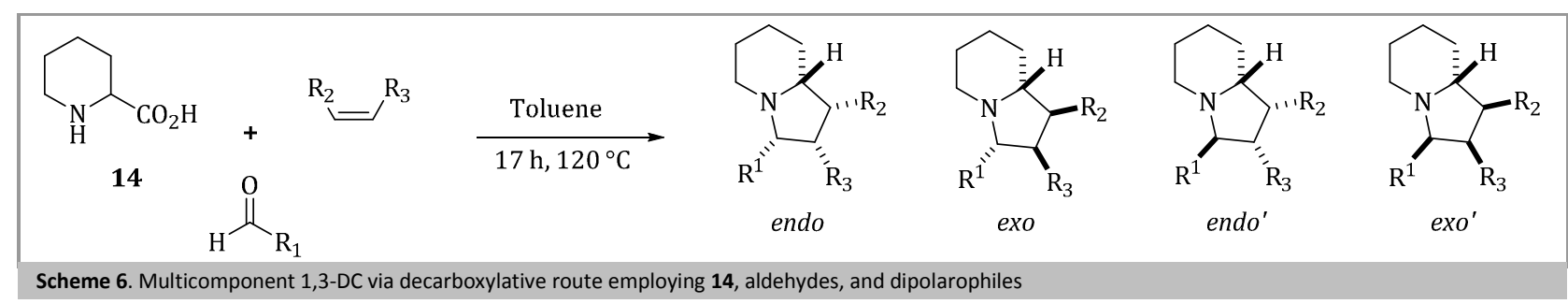

Table 1. Multicomponent 1,3-DC by mixing amino acid 14 , aldehydes, and dipolarophiles at $120^{\circ} \mathrm{C}$.

\begin{tabular}{cccccc} 
Entry & $\mathrm{R}^{1}$ & Dipolarophile & Product & Yield (\%) & $\begin{array}{c}d^{\mathrm{a}} \\
\text { (endo:exo:endo':exo') }\end{array}$ \\
1 & $(E)-\mathrm{PhCH}=\mathrm{CH}-$ & $\mathrm{NMM}$ & $\mathbf{1 5}$ & 89 & $35: 22: 20: 23$ \\
2 & $(E)-\mathrm{PhCH}=\mathrm{CH}-$ & $\mathrm{NPM}$ & $\mathbf{1 6}$ & 78 & $45: 17: 18: 20$ \\
3 & $(E)-\mathrm{PhCH}=\mathrm{CH}-$ & Dimethyl fumarate & $\mathbf{1 7}$ & 75 & $33: 29: 18: 20$ \\
4 & $(E)-\mathrm{PhCH}=\mathrm{CH}-$ & Diisobutyl fumarate & $\mathbf{1 8}$ & 75 & $35: 30: 19: 17$ \\
5 & $(E)-\mathrm{PhCH}=\mathrm{CH}-$ & tert-Butyl acrylate & $\mathbf{1 9}$ & 52 & $39: 28: 17: 16$ \\
6 & $(E)-\mathrm{PhCH}=\mathrm{CH}-$ & trans- $\beta$-Nitrostyrene & $\mathbf{2 0}$ & 40 & $43: 25: 11: 21$ \\
7 & $\mathrm{Ph}$ & $\mathrm{NPM}$ & $\mathbf{2 1}$ & 95 & $57: 25: 13: 5$ \\
\hline
\end{tabular}

${ }^{\mathrm{a}}$ Overall chemical yield isolated after flash chromatography.

${ }^{\mathrm{b}}$ Mixture of diastereoisomers detected by ${ }^{1} \mathrm{H}-\mathrm{NMR}$ of the crude mixture and after the separation of all of the corresponding diastereoisomers.

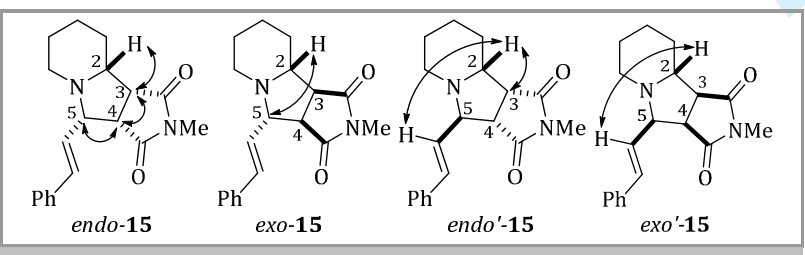

Figure 5. Representative nOe effects detected for adducts $\mathbf{1 5}$ derived from pipecolinic acid 14 and NMM.

As conclusion, we have prepared indolizidines from methyl pipecolinate and methyl 1,2,3,4-tetrahydroisoquinoline-3carboxylate in a multicomponent 1,3-DC using functionalized conjugate aldehydes as cinnamaldehyde and different dipolarophiles at $70{ }^{\circ} \mathrm{C}$. The major isomers resulted from the attack of the reactive $\mathrm{S}$-shape dipole, prepared via the iminium route, by its $\alpha$-position affording all cis-endo diasteroisomers. Under these reaction conditions, the diasteroselection was notably higher than the analogous ones reported in the literature at $110^{\circ} \mathrm{C}$. In other side, the appearance of the U-shape dipole at $120^{\circ} \mathrm{C}$ allowed to obtain two more diastereoisomers (endo' and exo') when the multicomponent sequence dealt with a dipole generated by a decarboxylative route. Here, endocycloadduct was the major isomer, especially when a bulky substituent in the dipolaophile was bonded $\left(\mathrm{Ph}, \mathrm{Bu}^{\mathrm{t}}, \mathrm{Bu}^{\mathrm{i}}\right)$ but with very significant amounts of the corresponding exo-adduct. In all these examples, the diasteromeric ratio was very low. No regioisomeric adducts controlled by a $\gamma$-attack were obtained in any case.

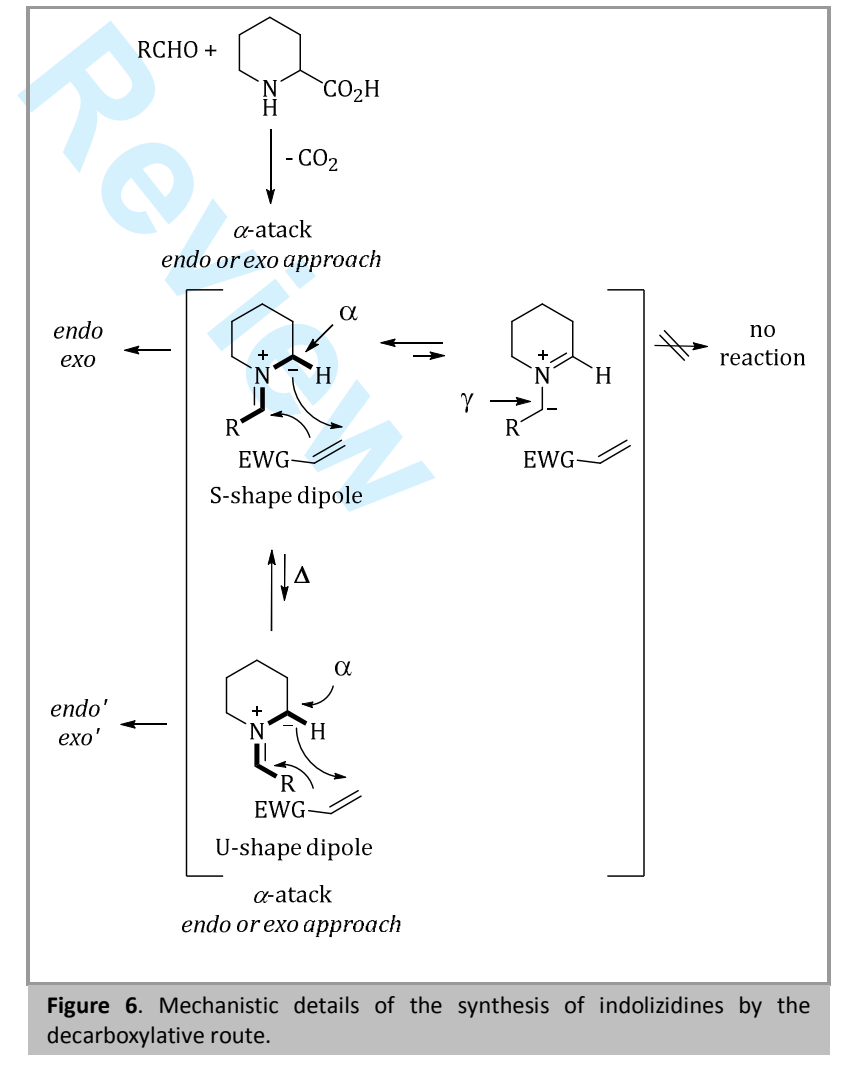

Figure 6. Mechanistic details of the synthesis of indolizidines by the decarboxylative route. 


\section{Experimental part}

Melting points were determined with a Reichert Thermovar hot plate apparatus and are uncorrected. Only the structurally most important peaks of the IR spectra, recorded on a Nicolet 510 P-FT, are listed. For solid samples ATR device was employed. ${ }^{1} \mathrm{H}-\mathrm{NMR}(300 \mathrm{MHz})$ and ${ }^{13} \mathrm{C}$ NMR $(75 \mathrm{MHz})$ spectra were obtained on a Bruker $\mathrm{AC}-300$ using $\mathrm{CDCl}_{3}$ as solvent and TMS as internal standard.

Low-resolution electron impact (EI) mass spectra were obtained at 70 eV on a Shimadzu QP-5000 and high-resolution mass spectra were obtained on a Finnigan VG Platform. HRMS (EI) were recorded on a Finnigan MAT 95S. Analytical TLC was performed on Schleicher \& Schuell F1400/LS silicagel plates and the spots were visualized under UV light $(\lambda=254 \mathrm{~nm})$. Flash chromatography was done using Merck silica gel $60(0.040-0.063 \mathrm{~mm})$.

\section{General procedure for the synthesis of indolizidines 3-9}

To a solution of the pipecolic acid methyl ester hydrochloride $\mathbf{1}(40 \mathrm{mg}$, $0.22 \mathrm{mmol})$ in toluene $(1 \mathrm{~mL}), \mathrm{Et}_{3} \mathrm{~N}(1$ equiv, $30.5 \mu \mathrm{L}, 0.22 \mathrm{mmol})$, the corresponding aldehyde (1 equiv, $0.22 \mathrm{mmol}$ ) and the dipolarophile (1 equiv, $0.22 \mathrm{mmol}$ ) were added. The resulting mixture was stirred at 70 ${ }^{\circ} \mathrm{C}$ for $17 \mathrm{~h}$. EtOAc $(5 \mathrm{~mL})$ and $\mathrm{H}_{2} \mathrm{O}(5 \mathrm{~mL})$ were added and the organic phase was separated, dried $\left(\mathrm{MgSO}_{4}\right)$, and evaporated to obtain the crude heterocycle, which was purified by flash chromatography (silica-gel) in chemical yields reported along the text.

\section{Methyl $\quad\left(3 \mathrm{a} S^{*}, 4 S^{*}, 9 \mathrm{a} R^{*}, 9 \mathrm{~b} R^{*}\right)-2$-methyl-1,3-dioxo-4-[(E)- styryl]decahydro-9a $H$-pyrrolo[3,4- $a$ ]indolizine-9a-carboxylate} (endo-2)

Yield: $36 \mathrm{mg}(59 \%)$, colorless prims, $\mathrm{mp} 134-135^{\circ} \mathrm{C}\left(\mathrm{Et}_{2} \mathrm{O}\right)$

IR (neat): 1734, 1698, $1213 \mathrm{~cm}^{-1}$.

${ }^{1} \mathrm{H}-\mathrm{NMR}: \delta=1.18\left(\mathrm{dt}, J=13.3,3.5 \mathrm{~Hz}, 1 \mathrm{H}, \mathrm{NCH}_{2} \mathrm{CH}_{2} \mathrm{CH}_{2}\right), 1.27-1.48(\mathrm{~m}$, $\left.1 \mathrm{H}, \mathrm{NCH}_{2} \mathrm{CH}_{2} \mathrm{CH}_{2}\right), 1.45-1.63\left(\mathrm{~m}, 2 \mathrm{H}, \mathrm{NCH}_{2} \mathrm{CH}_{2}\right), 1.74(\mathrm{dt}, J=13.2,3.4 \mathrm{~Hz}$, $\left.1 \mathrm{H}, \mathrm{CCH}_{2}\right), 2.48$ (ddd, $\left.J=13.2,2.9,1.4 \mathrm{~Hz}, 1 \mathrm{H}, \mathrm{CCH}_{2}\right), 2.81,2.84(2 \mathrm{xd}, J=$ $\left.2.7 \mathrm{~Hz}, 2 \mathrm{H}, \mathrm{NCH}_{2}\right), 3.01\left(\mathrm{~s}, 3 \mathrm{H}, \mathrm{NCH}_{3}\right), 3.25(\mathrm{dd}, J=8.0,7.9 \mathrm{~Hz}, 1 \mathrm{H}$, $\mathrm{NCHCH}), 3.35(\mathrm{~d}, J=7.9 \mathrm{~Hz}, 1 \mathrm{H}, \mathrm{CC} H), 3.76\left(\mathrm{~s}, 3 \mathrm{H}, \mathrm{OCH}_{3}\right), 4.18(\mathrm{dd}, J=9.2$, 8.0, $\mathrm{Hz}, 1 \mathrm{H}, \mathrm{NCH}$ ) 5.88 (dd, $J=15.6,9.2 \mathrm{~Hz}, 1 \mathrm{H}, \mathrm{PhCHCH}), 6.68$ (d, $J=15.6$ $\mathrm{Hz}, 1 \mathrm{H}, \mathrm{PhCH}), 7.22-7.35(\mathrm{~m}, 3 \mathrm{H}, \mathrm{ArH}), 7.36-7.45(\mathrm{~m}, 2 \mathrm{H}, \mathrm{ArH})$.

${ }^{13} \mathrm{C}$-NMR: $\delta=21.7\left(\mathrm{NCH}_{2} \mathrm{CH}_{2} \mathrm{CH}_{2}\right), 24.7\left(\mathrm{NCH}_{2} \mathrm{CH}_{2}\right), 25.1\left(\mathrm{NCH}_{3}\right), 32.0$ $\left(\mathrm{CCH}_{2}\right), 43.8\left(\mathrm{NCH}_{2}\right), 47.9(\mathrm{NCHCHCO}), 51.4(\mathrm{CCHCO}), 51.8\left(\mathrm{OCH}_{3}\right), 65.2$ $(\mathrm{NCH}), 69.9\left(\mathrm{CCO}_{2} \mathrm{Me}\right), 126.7,127.8,128.6,128.7,134.5,136.8(\mathrm{ArC}$ $C=C), 173.6,175.3(2 \times N C O), 175.9\left(\mathrm{CO}_{2} \mathrm{Me}\right)$.

MS (EI): $m / z=368$ (M+, 3\%), 310 (20), 309 (100), 224 (3).

HRMS (DIP) calcd. for $\mathrm{C}_{21} \mathrm{H}_{24} \mathrm{~N}_{2} \mathrm{O}_{4}$ : 368.1746; found 368.1750 .

Methyl $\quad\left(3 \mathrm{a} S^{*}, 4 S^{*}, 9 \mathrm{a} R^{*}, 9 \mathrm{~b} R^{*}\right)$-1,3-dioxo-2-phenyl-4-[(E)styryl]decahydro-9a $H$-pyrrolo[3,4-a]indolizine-9a-carboxylate (endo-3)

Yield: $52 \mathrm{mg}$ (55\%), pale yellow oil.

IR (neat): 2933, 1710, 1498, 1448, 1375, 1179, 1309, $1192 \mathrm{~cm}^{-1}$.

${ }^{1} \mathrm{H}-\mathrm{NMR}: \quad \delta=1.17-1.23\left(\mathrm{~m}, 1 \mathrm{H}, \mathrm{NCH}_{2} \mathrm{CH}_{2} \mathrm{CH}_{2}\right), 1.28-1.35(\mathrm{~m}, 1 \mathrm{H}$, $\left.\mathrm{NCH}_{2} \mathrm{CH}_{2} \mathrm{CH}_{2}\right), 1.38-1.48\left(\mathrm{~m}, 1 \mathrm{H}, \mathrm{NCH}_{2} \mathrm{CH}_{2}\right), 1.62-1.68\left(\mathrm{~m}, 1 \mathrm{H}, \mathrm{NCH}_{2} \mathrm{CH}_{2}\right)$, $1.78\left(\mathrm{dt}, J=13.1,3.2 \mathrm{~Hz}, 1 \mathrm{H}, \mathrm{CCH}_{2}\right), 2.53\left(\mathrm{dd}, J=13.1,1.5 \mathrm{~Hz}, 1 \mathrm{H}, \mathrm{CCH}_{2}\right)$, 2.82-2.93 (m, $\left.2 \mathrm{H}, \mathrm{NCH}_{2}\right), 3.41(\mathrm{t}, J=8.0, \mathrm{~Hz}, 1 \mathrm{H}, \mathrm{NCHCH}), 3.51(\mathrm{~d}, J=8.0$ $\mathrm{Hz}, 1 \mathrm{H}, \mathrm{CCH}), 3.79\left(\mathrm{~s}, 3 \mathrm{H}, \mathrm{OCH}_{3}\right), 4.29$ (dd, $\left.J=8.9,8.0, \mathrm{~Hz}, 1 \mathrm{H}, \mathrm{NCH}\right), 6.01$ (dd, $J=15.7,8.9 \mathrm{~Hz}, 1 \mathrm{H}, \mathrm{PhCHCH}), 6.72(\mathrm{~d}, J=15.7 \mathrm{~Hz}, 1 \mathrm{H}, \mathrm{PhCH}), 7.16-$ 7.35 (m, 5H, ArH), 7.37-7.50 (m, 5H, ArH).

${ }^{13} \mathrm{C}$-NMR: $\delta=21.8\left(\mathrm{NCH}_{2} \mathrm{CH}_{2} \mathrm{CH}_{2}\right), 24.9\left(\mathrm{NCH}_{2} \mathrm{CH}_{2}\right), 32.1\left(\mathrm{CCH}_{2}\right), 44.0$ $\left(\mathrm{NCH}_{2}\right), 48.0$ (NCHCHCO), $51.4(\mathrm{CCHCO}), 51.9\left(\mathrm{OCH}_{3}\right), 65.5(\mathrm{NCH}), 70.4$ $\left(\mathrm{CCO}_{2} \mathrm{Me}\right), 126.7,126.9,127.7,127.9,128.6,128.8,129.3,132.0,134.4$, $136.8(\mathrm{ArC}, \mathrm{C}=\mathrm{C}), 173.6(\mathrm{CO}), 174.2(\mathrm{CO}), 175.0\left(\mathrm{CO}_{2} \mathrm{Me}\right)$.

MS (EI): $m / z=430\left(M^{+}, 3 \%\right), 372$ (26), 371 (100), 224 (6).

HRMS (DIP) calcd. for $\mathrm{C}_{26} \mathrm{H}_{26} \mathrm{~N}_{2} \mathrm{O}_{4}: 430.1893$; found 430.1911 .
Methyl $\quad\left(3 \mathrm{a} S^{*}, 4 S^{*}, 9 \mathrm{a} R^{*}, 9 \mathrm{~b} R^{*}\right)-1,3-d i o x o-4-[(E)$-styryl]octahydro$3 \mathrm{H}, 9 \mathrm{aH}$-furo[3,4-a] indolizine-9a-carboxylate (endo-4)

Yield: $72 \mathrm{mg}(93 \%)$, colorless prisms, $\mathrm{mp} 146-148{ }^{\circ} \mathrm{C}\left(\mathrm{Et}_{2} \mathrm{O}\right)$.

IR (neat): 1774, 1734, $1226 \mathrm{~cm}^{-1}$.

${ }^{1} \mathrm{H}$-NMR: $\delta=1.15-1.25\left(\mathrm{~m}, 1 \mathrm{H}, \mathrm{NCH}_{2} \mathrm{CH}_{2} \mathrm{CH}_{2}\right), 1.50$ (ddt $J=12.9,8.4,3.9$ $\left.\mathrm{Hz}, 1 \mathrm{H}, \mathrm{NCH}_{2} \mathrm{CH}_{2} \mathrm{CH}_{2}\right), 1.58-1.69\left(\mathrm{~m}, 1 \mathrm{H}, \mathrm{NCH}_{2} \mathrm{CH}_{2}\right), 1.67-1.85(\mathrm{~m}, 2 \mathrm{H}$, $\mathrm{CCH}_{2}, \mathrm{NCH}_{2} \mathrm{CH}_{2}$ ), 2.45 (ddd, $J=12.7,4.5,1.9 \mathrm{~Hz}, 1 \mathrm{H}, \mathrm{CCH}_{2}$ ), 2.90 (d, $J=2.7$ $\left.\mathrm{Hz}, 1 \mathrm{H}, \mathrm{NCH}_{2}\right), 2.93\left(\mathrm{~d}, J=2.7 \mathrm{~Hz}, 1 \mathrm{H}, \mathrm{NCH}_{2}\right), 3.54(\mathrm{dd}, J=8.5,8.3 \mathrm{~Hz}, 1 \mathrm{H}$ $\mathrm{NCHCH}), 3.71(\mathrm{~d}, J=8.5 \mathrm{~Hz}, 1 \mathrm{H}, \mathrm{CCH}), 3.79\left(\mathrm{~s}, 3 \mathrm{H}, \mathrm{OCH}_{3}\right), 4.27$ (dd, $J=9.3$, $8.3 \mathrm{~Hz}, 1 \mathrm{H}, \mathrm{NCH}), 5.98$ (dd, $J=15.7,9.3 \mathrm{~Hz}, 1 \mathrm{H}, \mathrm{PhCHCH}), 6.73$ (d, $J=15.7$ $\mathrm{Hz}, 1 \mathrm{H}, \mathrm{PhCH}), 7.26-7.36(\mathrm{~m}, 3 \mathrm{H}, \mathrm{ArH}), 7.39-7.44(\mathrm{~m}, 2 \mathrm{H}, \mathrm{ArH})$.

${ }^{13} \mathrm{C}$-NMR: $\delta=21.3\left(\mathrm{NCH}_{2} \mathrm{CH}_{2} \mathrm{CH}_{2}\right), 24.3\left(\mathrm{NCH}_{2} \mathrm{CH}_{2}\right), 31.5\left(\mathrm{CCH}_{2}\right), 44.1$ $\left(\mathrm{NCH}_{2}\right), 48.4(\mathrm{NCHCHCO}), 52.0(\mathrm{CCHCO}), 52.4\left(\mathrm{OCH}_{3}\right), 66.0(\mathrm{NCH}), 70.6$ $\left(\mathrm{CCO}_{2} \mathrm{Me}\right), 125.5,127.1,128.4,128.8,136.2,136.4(\mathrm{ArC}, \mathrm{C}=\mathrm{C}), 169.0$ $169.4(2 \times \mathrm{NCO}), 172.4\left(\mathrm{CO}_{2} \mathrm{Me}\right)$.

MS (EI): $m / z=355$ (M+, 5\%), 297 (20), 296 (100), 225 (10), 224 (50). HRMS (DIP) calcd. for $\mathrm{C}_{20} \mathrm{H}_{21} \mathrm{NO}_{5}$ : 355.1420 ; found 355.1426 .

Dimethyl $\left(2 S^{*}, 3 S^{*}, 8 \mathrm{a} R^{*}\right)-3-[(E)$-styryl]hexahydroindolizine2,8a(1H)-dicarboxylate (endo-5)

Yield: $43 \mathrm{mg}$ (57\%), yellow solid, $\mathrm{mp} 189-190{ }^{\circ} \mathrm{C}\left(\mathrm{Et}_{2} \mathrm{O}\right)$.

IR (neat): 2977, 2946, 1745, $1474 \mathrm{~cm}^{-1}$.

${ }^{1} \mathrm{H}$-NMR: $\delta=1.11-1.17\left(\mathrm{~m}, 1 \mathrm{H}, \mathrm{NCH}_{2} \mathrm{CH}_{2} \mathrm{CH}_{2}\right), 1.33-1.51(\mathrm{~m}, 2 \mathrm{H}$, $\left.\mathrm{NCH}_{2} \mathrm{CH}_{2}, \mathrm{NCH}_{2} \mathrm{CH}_{2} \mathrm{CH}_{2}\right), 1.52-1.60\left(\mathrm{~m}, 1 \mathrm{H}, \mathrm{NCH}_{2} \mathrm{CH}_{2}\right), 1.65-1.75(\mathrm{~m}, 1 \mathrm{H}$, $\left.\mathrm{CCH}_{2}\right), 2.15\left(\mathrm{dd}, J=12.4,8.0, \mathrm{~Hz}, 1 \mathrm{H}, \mathrm{CHCH}_{2}\right), 2.24$ (dd, $J=12.4,10.8, \mathrm{~Hz}$ $\left.1 \mathrm{H}, \mathrm{CHCH}_{2}\right), 2.40\left(\mathrm{dtd}, J=12.4,3.3,1.2 \mathrm{~Hz}, 1 \mathrm{H}, \mathrm{CCH}_{2}\right), 2.68(\mathrm{td}, J=11.7$, $3.3 \mathrm{~Hz}, 1 \mathrm{H}, \mathrm{NCH}_{2}$ ), 2.80 (dd, $J=11.7,3.9 \mathrm{~Hz}, 1 \mathrm{H}, \mathrm{NCH}_{2}$ ), $3.20(\mathrm{td}, J=10.5$ $8.0 \mathrm{~Hz}, 1 \mathrm{H}, \mathrm{NCHCH}$ ), 3.53 (s, 3H, $\left.\mathrm{CHCO}_{2} \mathrm{CH}_{3}\right), 3.70\left(\mathrm{~s}, 3 \mathrm{H}, \mathrm{CCO}_{2} \mathrm{CH}_{3}\right), 4.10$ (ddd, $J=10.8,8.8,8.0 \mathrm{~Hz}, 1 \mathrm{H}, \mathrm{NCH}), 5.91(\mathrm{dd}, J=15.8,8.8 \mathrm{~Hz}, 1 \mathrm{H}$ PhCHCH), $6.53(\mathrm{~d}, J=15.8 \mathrm{~Hz}, 1 \mathrm{H}, \mathrm{PhCH}), 7.15-7.21(\mathrm{~m}, 1 \mathrm{H}, \mathrm{Ar} H), 7.23-$ $7.30(\mathrm{~m}, 2 \mathrm{H}, \mathrm{ArH}), 7.31-7.38(\mathrm{~m}, 2 \mathrm{H}, \mathrm{Ar} H)$

${ }^{13} \mathrm{C}$-NMR: $\delta=22.0\left(\mathrm{NCH}_{2} \mathrm{CH}_{2} \mathrm{CH}_{2}\right), 25.3\left(\mathrm{NCH}_{2} \mathrm{CH}_{2}\right), 34.6\left(\mathrm{CCH}_{2} \mathrm{CH}_{2}\right), 39.0$ $\left(\mathrm{CCH}_{2} \mathrm{CH}\right), 43.4\left(\mathrm{NCH}_{2}\right), 45.5\left(\mathrm{CHCO}_{2} \mathrm{Me}\right), 51.2\left(\mathrm{OCH}_{3}\right), 51.6\left(\mathrm{OCH}_{3}\right), 65.2$ $(\mathrm{NCH}), 68.6\left(\mathrm{CCO}_{2} \mathrm{Me}\right), 126.4,127.5,128.5,129.7,132.9,136.9(\mathrm{ArC}$ $C=C), 173.3\left(\mathrm{CO}_{2} \mathrm{Me}\right), 175.6\left(\mathrm{CO}_{2} \mathrm{Me}\right)$.

MS (EI): $m / z=343\left(\mathrm{M}^{+}, 2 \%\right), 285$ (20), 284 (100), 224 (12).

HRMS (DIP) calcd. for $\mathrm{C}_{20} \mathrm{H}_{25} \mathrm{NO}_{4}$ : 343.1784 ; found: 343.1800 .

Trimethyl $\left(1 S^{*}, 2 S^{*}, 3 S^{*}, 8 \mathrm{a} R^{*}\right)-3-[(E)$-styryl]hexahydroindolizine1,2,8a(1H)-tricarboxylate (endo-6)

Yield: $62 \mathrm{mg}(70 \%)$, pale yellow oil.

IR (neat): 1732, 1201, $1167 \mathrm{~cm}^{-1}$.

${ }^{1} \mathrm{H}$-NMR: $\delta=1.24$ (tdd, $J=13.5,8.8,3.9 \mathrm{~Hz}, 1 \mathrm{H}, \mathrm{NCH}_{2} \mathrm{CH}_{2} \mathrm{CH}_{2}$ ), $1.46-1.65$ (m, $3 \mathrm{H}, \mathrm{NCH}_{2} \mathrm{CH}_{2}, \mathrm{NCH}_{2} \mathrm{CH}_{2} \mathrm{CH}_{2}$ ), 1.68-1.79 (m, $\left.1 \mathrm{H}, \mathrm{CCH}_{2}\right), 2.40-2.72(\mathrm{~m}$, $\left.2 \mathrm{H}, \mathrm{NCH}_{2}, \mathrm{CCH}_{2}\right), 2.76-2.85\left(\mathrm{~m}, 1 \mathrm{H}, \mathrm{NCH}_{2}\right), 3.43(\mathrm{~d}, J=10.8 \mathrm{~Hz}, 1 \mathrm{H}, \mathrm{CCH})$ $3.55\left(\mathrm{~s}, 3 \mathrm{H}, \mathrm{CHCO}_{2} \mathrm{CH}_{3}\right), 3.68\left(\mathrm{~s}, 3 \mathrm{H}, \mathrm{CHCO}_{2} \mathrm{CH}_{3}\right), 3.69$ (dd, $J=10.8,10.5$ $\mathrm{Hz}, 1 \mathrm{H}, \mathrm{NCHCH}), 3.70\left(\mathrm{~s}, 3 \mathrm{H}, \mathrm{CCO}_{2} \mathrm{CH}_{3}\right), 4.19$ (dd, $J=10.5,9.1 \mathrm{~Hz}, 1 \mathrm{H}$ $\mathrm{NCH}), 5.87(\mathrm{dd},=15.8,9.1 \mathrm{~Hz}, 1 \mathrm{H}, \mathrm{PhCHCH}), 6.55(\mathrm{~d}, J=15.8 \mathrm{~Hz}, 1 \mathrm{H}$, $\mathrm{PhCH})$, 7.19-7.37 (m, 5H, $\mathrm{ArH})$.

${ }^{13} \mathrm{C}$-NMR: $\delta=21.8\left(\mathrm{NCH}_{2} \mathrm{CH}_{2} \mathrm{CH}_{2}\right), 25.1\left(\mathrm{NCH}_{2} \mathrm{CH}_{2}\right), 34.5\left(\mathrm{CCH}_{2}\right), 43.8$ $\left(\mathrm{NCH}_{2}\right), 48.2(\mathrm{CCH}), 51.7(\mathrm{NCHCH}), 52.1\left(\mathrm{OCH}_{3}\right), 52.3\left(\mathrm{OCH}_{3}\right), 55.0$ $\left(\mathrm{OCH}_{3}\right), 64.4(\mathrm{NCH}), 70.9\left(\mathrm{CCO}_{2} \mathrm{Me}\right), 126.6,127.8,128.7,128.9,133.7$, $136.8(\mathrm{ArC}, \mathrm{C}=\mathrm{C}), 171.0\left(\mathrm{CCO}_{2} \mathrm{Me}\right), 172.3\left(\mathrm{CHCO}_{2} \mathrm{Me}\right), 172.8\left(\mathrm{CHCO}_{2} \mathrm{Me}\right)$.

MS (EI): $m / z=401\left(\mathrm{M}^{+}, 5 \%\right), 343$ (21), 342 (100), 310 (13), 282 (38), 250 (23).

HRMS (DIP) calcd. for $\mathrm{C}_{22} \mathrm{H}_{27} \mathrm{NO}_{6}$ : 401.1838; found 401.1849.

Methyl

$\left(1 S^{*}, 2 S^{*}, 3 S^{*}, 8 \mathrm{a} R^{*}\right)$-2-nitro-1-phenyl-3-[(E)styryl]hexahydroindolizine-8a(1H)-carboxylate (endo-7)

Yield: $15 \mathrm{mg}$ (17\%), brown sticky oil.

IR (neat): 1734, 1556, $1223 \mathrm{~cm}^{-1}$.

${ }^{1} \mathrm{H}$-NMR: $\delta=1.21-1.38\left(\mathrm{~m}, 2 \mathrm{H}, \mathrm{NCH}_{2} \mathrm{CH}_{2} \mathrm{CH}_{2}\right), 1.50-1.70(\mathrm{~m}, 2 \mathrm{H}$, $\left.\mathrm{NCH}_{2} \mathrm{CH}_{2}\right), 1.74-1.87\left(\mathrm{~m}, 1 \mathrm{H}, \mathrm{CCH}_{2}\right), 2.24-2.31\left(\mathrm{~m}, 1 \mathrm{H}, \mathrm{CCH}_{2}\right), 2.96-3.02$ $\left(\mathrm{m}, 2 \mathrm{H}, \mathrm{NCH}_{2}\right), 3.86\left(\mathrm{~s}, 3 \mathrm{H}, \mathrm{OCH}_{3}\right), 3.93(\mathrm{dd}, J=8.4,5.2 \mathrm{~Hz}, 1 \mathrm{H}, \mathrm{NCHCHPh})$ $4.08(\mathrm{t}, J=8.4 \mathrm{~Hz}, 1 \mathrm{H}, \mathrm{NCH}), 5.22\left(\mathrm{~d}, J=5.2,1 \mathrm{H}, \mathrm{CHNO}_{2}\right), 6.15(\mathrm{dd}, J=$ 15.8, 8.4 Hz, 1H, PhCHCH), 6.40 (d, J = 15.8 Hz, 1H, PhCH), 7.06-7.12 (m, $2 \mathrm{H}, \mathrm{Ar} H), 7.22-7.39(\mathrm{~m}, 8 \mathrm{H}, \mathrm{Ar} H)$. 
${ }^{13} \mathrm{C}-\mathrm{NMR}: \delta=21.6\left(\mathrm{NCH}_{2} \mathrm{CH}_{2} \mathrm{CH}_{2}\right), 24.6\left(\mathrm{NCH}_{2} \mathrm{CH}_{2}\right), 31.5\left(\mathrm{CCH}_{2}\right), 43.7$ $(\mathrm{NCHCHPh}), 52.4\left(\mathrm{NCH}_{2}\right), 54.5\left(\mathrm{OCH}_{3}\right), 71.5(\mathrm{NCH}), 72.0\left(\mathrm{CCO}_{2} \mathrm{Me}\right), 97.9$ $\left(\mathrm{CHNO}_{2}\right), 126.7,127.7,128.0,128.2,128.7,129.1,129.5,134.7,136.5$, $138.1(\mathrm{ArC}, \mathrm{C}=C), 172.8\left(\mathrm{CO}_{2} \mathrm{Me}\right)$.

MS (EI): $m / z=360\left(\mathrm{M}^{+}-\mathrm{NO}_{2}, 91 \%\right), 348$ (13), 347 (51), 302 (25), 301 (100), 300 (39), 224 (18), 210 (45), 198 (13).

HRMS (DIP) calcd. for $\mathrm{C}_{24} \mathrm{H}_{26} \mathrm{~N}_{2} \mathrm{O}_{4}\left(-\mathrm{NO}_{2}\right)$ : 360.1983 ; found: 360.1974 .

\section{Methyl}

$\left(1 S^{*}, 2 R^{*}, 3 S^{*}, 8 \mathrm{a} R^{*}\right)-1-$ nitro-2-phenyl-3-[(E)styryl]hexahydroindolizine-8a(1H)-carboxylate (exo-8)

Yield: $62 \mathrm{mg}(55 \%)$, colorless prisms, $\mathrm{mp} 146-148^{\circ} \mathrm{C}\left(\mathrm{Et}_{2} \mathrm{O}\right)$. IR (neat): $1543,1354 \mathrm{~cm}^{-1}$.

${ }^{1} \mathrm{H}-\mathrm{NMR}: \delta=1.08-1.32\left(\mathrm{~m}, 2 \mathrm{H}, \mathrm{NCH}_{2} \mathrm{CH}_{2} \mathrm{CH}_{2}\right), 1.47-1.65(\mathrm{~m}, 2 \mathrm{H}$, $\left.\mathrm{NCH}_{2} \mathrm{CH}_{2}\right), 1.69-1.82\left(\mathrm{~m}, 1 \mathrm{H}, \mathrm{CCH}_{2}\right), 2.21-2.56\left(\mathrm{~m}, 2 \mathrm{H}, \mathrm{NCH}_{2}, \mathrm{CCH}_{2}\right)$, 2.86-2.93 (m, $\left.1 \mathrm{H}, \mathrm{NCH}_{2}\right), 3.43\left(\mathrm{~s}, 3 \mathrm{H}, \mathrm{OCH}_{3}\right), 4.09(\mathrm{~d}, J=10.0 \mathrm{~Hz}, 1 \mathrm{H}$, CCHPh), $4.69(\mathrm{dd}, J=9.6,8.4 \mathrm{~Hz}, 1 \mathrm{H}, \mathrm{NCH}), 5.74(\mathrm{dd}, J=10.0,9.6 \mathrm{~Hz}, 1 \mathrm{H}$, $\mathrm{CHNO}_{2}$ ), $5.90(\mathrm{dd}, J=15.8,8.4 \mathrm{~Hz}, 1 \mathrm{H}, \mathrm{PhCHCH}), 6.72(\mathrm{~d}, J=15.8 \mathrm{~Hz}, 1 \mathrm{H}$, $\mathrm{PhCH}), 7.08-7.21(\mathrm{~m}, 2 \mathrm{H}, \mathrm{ArH}), 7.27-7.34(\mathrm{~m}, 6 \mathrm{H}, \mathrm{ArH}), 7.35-7.42(\mathrm{~m}$, $2 \mathrm{H}, \mathrm{Ar} H$ ).

${ }^{13} \mathrm{C}-\mathrm{NMR}: \delta=21.9\left(\mathrm{NCH}_{2} \mathrm{CH}_{2} \mathrm{CH}_{2}\right), 25.1\left(\mathrm{NCH}_{2} \mathrm{CH}_{2}\right), 33.6\left(\mathrm{CCH}_{2}\right), 44.6$ (CCHPh), $51.1\left(\mathrm{NCH}_{2}\right), 57.9\left(\mathrm{OCH}_{3}\right), 65.7(\mathrm{NCH}), 73.4\left(\mathrm{CCO}_{2} \mathrm{Me}\right), 91.1$ $\left(\mathrm{CHNO}_{2}\right), 126.0,127.0,127.9,127.9,128.2,128.4,128.6,128.8,133.5$, $136.3(\mathrm{Ar} C, C=C), 173.6\left(\mathrm{CO}_{2} \mathrm{Me}\right)$.

MS (EI): $m / z=360\left(\mathrm{M}^{+}-\mathrm{NO}_{2}, 57 \%\right), 348$ (19), 347 (80), 301 (33), 300 (100).

HRMS (DIP) calcd. for $\mathrm{C}_{24} \mathrm{H}_{26} \mathrm{~N}_{2} \mathrm{O}_{4}\left(-\mathrm{NO}_{2}\right): 360.1983$; found: 360.1974 .

Methyl $\left(1 R^{*}, 2 S^{*}, 3 S^{*}, 8 a R^{*}\right)-2$-benzoyl-1-phenyl-3-[(E)styryl]hexahydroindolizine-8a(1H)-carboxylate (endo-9) and Methyl $\left(1 S^{*}, 2 R^{*}, 3 S^{*}, 8 \mathrm{a} R^{*}\right)$-2-benzoyl-1-phenyl-3-[(E)styryl]hexahydroindolizine-8a(1H)-carboxylate (exo-9)

Yield: $68 \mathrm{mg}(66 \%)$, colorless sticky oil.

IR (neat): 1718, 1682, 1447, $1207 \mathrm{~cm}^{-1}$.

1H-NMR: $\delta$ (mixture of endo:exo 0.33:1) $=1.13-1.19(\mathrm{~m}$, exo- $2 \mathrm{H}$, $\left.\mathrm{NCHCHCH}_{2}\right), 1.20-1.24(\mathrm{~m}$, endo- $2 \mathrm{H}, \mathrm{NCHCHCH} 2), 1.49-1.56(\mathrm{~m}$, endo- $-\mathrm{H}$, $\mathrm{NCHCH}_{2}$, exo-2H, $\left.\mathrm{NCHCH}_{2}\right), 1.68-1.81\left(\mathrm{~m}\right.$, endo- $1 \mathrm{H}, \mathrm{CCH}_{2}$, exo-1 $\left.\mathrm{H}, \mathrm{CCH}_{2}\right)$, 1.88-1.93 (m, endo- $\left.2 \mathrm{H}, \mathrm{NCH}_{2}, \mathrm{CCH}_{2}\right), 2.36(\mathrm{dt}, J=12.3,3.4 \mathrm{~Hz}$, exo- $1 \mathrm{H}$, $\left.\mathrm{CCH}_{2}\right), 2.49\left(\mathrm{td}, J=11.4,4.0 \mathrm{~Hz}\right.$, exo-1H, $\left.\mathrm{NCH}_{2}\right), 2.87$ (dd, $J=15.3,3.8 \mathrm{~Hz}$, exo-1 $\left.\mathrm{H}, \mathrm{NCH}_{2}\right), 2.96-2.92\left(\mathrm{~m}\right.$, endo- $\left.1 \mathrm{H}, \mathrm{NCH}_{2}\right), 3.42\left(\mathrm{~s}\right.$, exo- $\left.3 \mathrm{H}, \mathrm{OCH}_{3}\right)$, $3.90(\mathrm{dd}, J=8.5,6.3 \mathrm{~Hz}$, endo- $1 \mathrm{H}, \mathrm{NCHCH}), 3.93$ (s, endo-3H, $\mathrm{OCH}_{3}$ ), 4.03 (d, $J=11.2 \mathrm{~Hz}$, exo-1H, CCH), 4.13 (dd, $J=8.5,8.3 \mathrm{~Hz}$, endo- $1 \mathrm{H}, \mathrm{NCH}$ ), 4.26 (d, $J=6.3 \mathrm{~Hz}$, endo- $1 \mathrm{H}, \mathrm{CCH}$ ), 4.58 (dd, $J=10.2,8.8 \mathrm{~Hz}$, exo- $1 \mathrm{H}, \mathrm{NCH}$ ), 4.85 (dd, $J=11.2,10.2 \mathrm{~Hz}$, exo-1H, NCHCH), 5.71 (dd, $J=15.7,8.8 \mathrm{~Hz}$, exo $-1 \mathrm{H}$, $\mathrm{PhCHCH}), 6.20(\mathrm{dd}, J=15.9,8.3 \mathrm{~Hz}$, endo-1H, $\mathrm{PhCHCH}), 6.30(\mathrm{~d}, J=15.7$ $\mathrm{Hz}$, exo-1H, PhCH), 6.37 (d, $J=15.9 \mathrm{~Hz}$, endo- $1 \mathrm{H}, \mathrm{PhCH}), 7.04-7.23(\mathrm{~m}$, endo-9H, exo-9H, $\mathrm{ArH}$ ), 7.28-7.46 (m, endo- $4 \mathrm{H}$, exo- $4 \mathrm{H}, \mathrm{Ar} H)$, 7.83-7.92 $(\mathrm{m}$, exo- $2 \mathrm{H}, \mathrm{ArH}), 8.01-8.08$ ( $\mathrm{m}$, endo- $2 \mathrm{H}, \mathrm{ArH})$.

${ }^{13} \mathrm{C}$-NMR: $\delta$ (major diastereoisomer) $=22.3\left(\mathrm{NCH}_{2} \mathrm{CH}_{2} \mathrm{CH}_{2}\right), 25.4$ $\left(\mathrm{NCH}_{2} \mathrm{CH}_{2}\right), 33.8\left(\mathrm{CCH}_{2}\right), 44.0\left(\mathrm{NCH}_{2}\right), 50.8(\mathrm{CCHPh}), 51.9(\mathrm{CHCO}), 55.2$ $\left(\mathrm{OCH}_{3}\right), 65.8(\mathrm{NCH}), 73.6\left(\mathrm{CCO}_{2} \mathrm{Me}\right), 126.5,126.6,127.4,127.5,128.1$, 128.1, 128.3, 128.4, 128.4, 128.5, 128.5, 128.6, 128.7, 128.9, 129.9, 133.0, 133.0, 136.7, 137.0, 138.1 ( $\mathrm{ArC}, C=C), 174.6\left(\mathrm{CO}_{2} \mathrm{Me}\right), 198.5(\mathrm{CO})$.

MS (EI): $m / z=465\left(\mathrm{M}^{+}, 3 \%\right), 407$ (30), 406 (100), 360 (8).

HRMS (DIP) calcd. for $\mathrm{C}_{31} \mathrm{H}_{31} \mathrm{NO}_{3}$ : 465.2324; found 465.2334.

\section{General procedure for the synthesis of indolizidine 11}

To a solution of the amine $\mathbf{1 0}$ (40 $\mathrm{mg}, 0.21 \mathrm{mmol})$ in toluene $(1 \mathrm{~mL})$, the corresponding aldehyde ( 1 equiv, $0.21 \mathrm{mmol}$ ) and the dipolarophile (1 equiv, $0.21 \mathrm{mmol}$ ) were added. The resulting mixture was stirred at 70 ${ }^{\circ} \mathrm{C}$ for $17 \mathrm{~h}$. The solvent was evaporated and the heterocycles were separated by flash chromatography (silica-gel) in good chemical yields (see text).

Methyl $\left(3 \mathrm{a} S^{*}, 4 S^{*}, 11 \mathrm{a} R^{*}, 11 \mathrm{~b} R^{*}\right)-1,3-\operatorname{dioxo}-2-p h e n y l-4-[(E)$-styryl]1,2,3,3a,4,6,11,11b-octahydro-11a $H$-pyrrolo[3',4':3,4]pyrrolo[1,2b]isoquinoline-11a-carboxylate (endo-11)

Yield: $68 \mathrm{mg}$ (65\%), white solid, $\mathrm{mp} 209-212^{\circ} \mathrm{C}\left(\mathrm{Et}_{2} \mathrm{O}\right)$.

IR (neat): 1703, 1494, 1396, $1203 \mathrm{~cm}^{-1}$.
${ }^{1} \mathrm{H}$-NMR: $\delta=2.98\left(\mathrm{~d}, J=16.8 \mathrm{~Hz}, 1 \mathrm{H}, \mathrm{CCH}_{2}\right), 3.44(\mathrm{~d}, J=8.0 \mathrm{~Hz}, 1 \mathrm{H}$, CCHCO), 3.52 (d, $J=16.8 \mathrm{~Hz}, 1 \mathrm{H}, \mathrm{CCH}_{2}$ ), $3.55(\mathrm{dd}, J=8.2,8.0 \mathrm{~Hz}, 1 \mathrm{H}$, $\mathrm{NCHCH}), 3.72\left(\mathrm{~s}, 3 \mathrm{H}, \mathrm{OCH}_{3}\right), 3.88(\mathrm{dd}, J=8.6,8.2 \mathrm{~Hz}, 1 \mathrm{H}, \mathrm{NCH}), 3.95(\mathrm{~d}, J=$ $\left.18.1 \mathrm{~Hz}, 1 \mathrm{H}, \mathrm{NCH}_{2}\right), 4.31\left(\mathrm{~d}, J=18.1 \mathrm{~Hz}, 1 \mathrm{H}, \mathrm{NCH}_{2}\right), 6.22(\mathrm{dd}, J=15.7,8.6$ $\mathrm{Hz}, 1 \mathrm{H}, \mathrm{PhCHCH}), 6.62(\mathrm{~d}, J=15.7 \mathrm{~Hz}, 1 \mathrm{H}, \mathrm{PhCH}), 6.94-7.06(\mathrm{~m}, 1 \mathrm{H}, \mathrm{Ar} H)$, 7.09-7.21 (m, 3H, ArH), 7.23-7.32 (m, 5H, ArH), 7.37-7.48 (m, 5H, ArH).

${ }^{13} \mathrm{C}-\mathrm{NMR}: \delta=30.2\left(\mathrm{CCH}_{2}\right), 45.4\left(\mathrm{NCH}_{2}\right), 47.4(\mathrm{NCHCHCO}), 52.8(\mathrm{CCHCO})$, $53.7\left(\mathrm{OCH}_{3}\right), 64.8(\mathrm{NCH}), 68.8\left(\mathrm{CCO}_{2} \mathrm{Me}\right), 126.2,126.5,126.6,126.9$ 127.1, 128.2, 128.7, 128.8, 129.0, 129.2, 130.6, 131.9, 135.2, 136.3 (ArC $C=C), 170.9(\mathrm{CO}), 174.2(\mathrm{CO}), 174.6\left(\mathrm{CO}_{2} \mathrm{Me}\right)$.

MS (EI): $m / z=478\left(\mathrm{M}^{+},<1 \%\right), 420$ (31), 419 (100), 180 (4).

HRMS (DIP) calcd. for $\mathrm{C}_{30} \mathrm{H}_{26} \mathrm{~N}_{2} \mathrm{O}_{4}: 478.1893$; found 478.1883 .

\section{General procedure for the synthesis of indolizidines 12-13}

To a solution of the pipecolic acid alkyl ester hydrochloride $\mathbf{1}(0.22$ $\mathrm{mmol}$ ) in toluene $(1 \mathrm{~mL}), \mathrm{Et}_{3} \mathrm{~N}$ (1 equiv, $\left.30.5 \mu \mathrm{L}, 0.22 \mathrm{mmol}\right)$, the corresponding aldehyde ( 1 equiv, $0.22 \mathrm{mmol}$ ) and the dipolarophile (1 equiv, $0.22 \mathrm{mmol}$ ) were added. The resulting mixture was stirred at 70 ${ }^{\circ} \mathrm{C}$ for $17 \mathrm{~h}$. EtOAc $(5 \mathrm{~mL})$ and $\mathrm{H}_{2} \mathrm{O}(5 \mathrm{~mL})$ were added and the organic phase was separated, dried $\left(\mathrm{MgSO}_{4}\right)$, and evaporated to obtain the crude product which was purified by flash chromatography (silica-gel) in good chemical yields (see text).

Methyl $\left(3 \mathrm{a} S^{*}, 4 R^{*}, 9 \mathrm{a} R^{*}, 9 \mathrm{~b} R^{*}\right)-1,3-d i o x o-4-p h e n y l o c t a h y d r o-3 H, 9 a H-$ furo[3,4-a]indolizine-9a-carboxylate (endo-12)

Yield: $20 \mathrm{mg}$ (27\%), yellow sticky oil.

IR (neat): 2927, 2856, 1781, 1733, 1209, 922, $734 \mathrm{~cm}^{-1}$.

${ }^{1} \mathrm{H}-\mathrm{NMR}$ : $\delta=1.53-1.39\left(\mathrm{~m}, 2 \mathrm{H}, \mathrm{NCHCHCH}_{2}\right), 1.55-1.65\left(\mathrm{~m}, 1 \mathrm{H}, \mathrm{NCH}_{2} \mathrm{CH}_{2}\right)$, $1.83\left(\mathrm{dt}, J=13.8,3.5 \mathrm{~Hz}, 1 \mathrm{H}, \mathrm{NCH}_{2} \mathrm{CH}_{2}\right), 1.96(\mathrm{td}, J=13.4,3.9 \mathrm{~Hz}, 1 \mathrm{H}$, $\left.\mathrm{CCH}_{2}\right), 2.45-2.55\left(\mathrm{~m}, 1 \mathrm{H}, \mathrm{CCH}_{2}\right), 2.65\left(\mathrm{dd}, J=11.9,4.3 \mathrm{~Hz}, 1 \mathrm{H}, \mathrm{NCH}_{2}\right), 2.78$ (td, $J=11.9,3.3 \mathrm{~Hz}, 1 \mathrm{H}, \mathrm{NCH}_{2}$ ), 3.61 (dd, $J=9.4,8.3 \mathrm{~Hz}, 1 \mathrm{H}, \mathrm{PhCHCH}$ ), 3.69 (d, $J=8.3 \mathrm{~Hz}, 1 \mathrm{H}, \mathrm{CCHCO}), 3.79$ (s, $\left.3 \mathrm{H}, \mathrm{OCH}_{3}\right), 4.75$ (d, $J=9.4 \mathrm{~Hz}, 1 \mathrm{H}$, $\mathrm{PhCH}), 7.22-7.28(\mathrm{~m}, 2 \mathrm{H}, \mathrm{ArH}), 7.29-7.40(\mathrm{~m}, 3 \mathrm{H}, \mathrm{ArH})$.

${ }^{13} \mathrm{C}-\mathrm{NMR}: \delta=21.4\left(\mathrm{NCH}_{2} \mathrm{CH}_{2} \mathrm{CH}_{2}\right), 24.6\left(\mathrm{NCH}_{2} \mathrm{CH}_{2}\right), 31.0\left(\mathrm{CCH}_{2}\right), 44.1$ $\left(\mathrm{NCH}_{2}\right), 49.6(\mathrm{NCHCHCO}), 52.2\left(\mathrm{OCH}_{3}\right), 52.1(\mathrm{CCHCO}), 67.7(\mathrm{NCH}), 70.9$ $\left(C \mathrm{CO}_{2} \mathrm{Me}\right), 127.8,128.6,128.8,128.9,130.2,136.5(\mathrm{ArC}, C=C), 169.0$, 169.2 (2xNCO), $172.9\left(\mathrm{CO}_{2} \mathrm{Me}\right)$.

MS (EI): $m / z=329\left(\mathrm{M}^{+},<1 \%\right), 271$ (18), 270 (100), 220 (8), 198 (67). HRMS (DIP) calcd. for $\mathrm{C}_{18} \mathrm{H}_{19} \mathrm{NO}_{5}\left(-\mathrm{CO}_{2} \mathrm{Me}\right): 270.1130$; found 270.1132 . Ethyl $\left(3 \mathrm{a} S^{*}, 4 R^{*}, 9 \mathrm{a} R^{*}, 9 \mathrm{~b} R^{*}\right)-4-($ furan-2-yl)-2-methyl-1,3-
dioxodecahydro-9aH-pyrrolo[3,4-a]indolizine-9a-carboxylate (endo-13)

Yield: $30 \mathrm{mg}$ (39\%), white prisms, $\mathrm{mp} 121-124^{\circ} \mathrm{C}\left(\mathrm{Et}_{2} \mathrm{O}\right)$.

IR (neat): 2936, 1699, 1432, 1377, 1281, 1230, 1148, 1006, $755 \mathrm{~cm}^{-1}$.

${ }^{1} \mathrm{H}-\mathrm{NMR}: \delta=1.21\left(\mathrm{dt}, J=13.3,3.8 \mathrm{~Hz}, 1 \mathrm{H}, \mathrm{NCH}_{2} \mathrm{CH}_{2} \mathrm{CH}_{2}\right), 1.32(\mathrm{t}, J=7.2$ $\mathrm{Hz}, 3 \mathrm{H}, \mathrm{CH}_{2} \mathrm{CH}_{3}$ ), 1.44 (ddd, $J=12.4,5.3,4.1 \mathrm{~Hz}, 1 \mathrm{H}, \mathrm{NCH}_{2} \mathrm{CH}_{2} \mathrm{CH}_{2}$ ), $1.51-$ $1.61\left(\mathrm{~m}, 1 \mathrm{H}, \mathrm{NCH}_{2} \mathrm{CH}_{2}\right), 1.78\left(\mathrm{dd}, J=13.9,6.0 \mathrm{~Hz}, 1 \mathrm{H}, \mathrm{NCH}_{2} \mathrm{CH}_{2}\right), 1.87$ (td, $J=13.2,3.7 \mathrm{~Hz}, 1 \mathrm{H}, \mathrm{CCH}_{2}$ ), $2.53\left(\mathrm{ddt}, J=13.2,4.6,2.1 \mathrm{~Hz}, 1 \mathrm{H}, \mathrm{CCH}_{2}\right.$ ), $2.56-$ $2.65\left(\mathrm{~m}, 1 \mathrm{H}, \mathrm{NCH}_{2}\right), 2.79\left(\mathrm{td}, J=11.7,3.5 \mathrm{~Hz}, 1 \mathrm{H}, \mathrm{NCH}_{2}\right), 2.93(\mathrm{~s}, 3 \mathrm{H}$, $\left.\mathrm{NCH}_{3}\right), 3.28-3.40(\mathrm{~m}, 2 \mathrm{H}, \mathrm{NCHCH}, \mathrm{CCH}), 4.23\left(\mathrm{q}, J=7.2 \mathrm{~Hz}, 2 \mathrm{H}, \mathrm{CH}_{2} \mathrm{CH}_{3}\right)$, $4.80(\mathrm{~d}, J=8.2 \mathrm{~Hz}, 1 \mathrm{H}, \mathrm{NCH}), 6.24(\mathrm{dd}, J=3.2,0.8 \mathrm{~Hz}, 1 \mathrm{H}, \mathrm{OCHCHCH}), 6.33$ $(\mathrm{dd}, J=3.2,1.9 \mathrm{~Hz}, 1 \mathrm{H}, \mathrm{OCHC} H), 7.38(\mathrm{dd}, J=1.9,0.8 \mathrm{~Hz}, 1 \mathrm{H}, \mathrm{OC} H)$.

${ }^{13} \mathrm{C}$-NMR: $\delta=14.5\left(\mathrm{CH}_{2} \mathrm{CH}_{3}\right), 21.6\left(\mathrm{NCH}_{2} \mathrm{CH}_{2} \mathrm{CH}_{2}\right), 24.7\left(\mathrm{NCH}_{2} \mathrm{CH}_{2}\right), 25.1$ $\left(\mathrm{NCH}_{3}\right), 30.9\left(\mathrm{CCH}_{2}\right), 44.3\left(\mathrm{NCH}_{2}\right), 47.0(\mathrm{NCHCHCO}), 51.3(\mathrm{CCHCO}), 61.0$ $\left(\mathrm{CH}_{2} \mathrm{CH}_{3}\right), 61.2(\mathrm{NCH}), 69.9\left(\mathrm{CCO}_{2} \mathrm{Et}\right), 109.2(\mathrm{OCHCH}), 110.3(\mathrm{OCCH})$, $142.8(\mathrm{OCH}), 151.1(\mathrm{OCCH}), 173.1,175.0(2 \times N C O), 175.8\left(\mathrm{CO}_{2} \mathrm{Et}\right)$.

MS (EI): $m / z=346\left(\mathrm{M}^{+},<1 \%\right), 274$ (16), 273 (100).

HRMS (DIP) calcd. for $\mathrm{C}_{18} \mathrm{H}_{22} \mathrm{~N}_{2} \mathrm{O}_{5}: 346.1529$; found: 346.1519 .

\section{General procedure for the synthesis of indolizidines 15-21}

To a solution of the pipecolinic acid 13 ( $40 \mathrm{mg}, 0.31 \mathrm{mmol}$ ) in toluene ( 1 $\mathrm{mL})$, the corresponding aldehyde (1 equiv, $0.31 \mathrm{mmol}$ ) and the dipolarophile ( 1 equiv, $0.31 \mathrm{mmol}$ ) were added. The resulting mixture was stirred in a pressure tube at $120{ }^{\circ} \mathrm{C}$ for $17 \mathrm{~h}$. The solvent was evaporated and the mixture was separated by flash chromatography affording the corresponding cycloadducts. 
HRMS (DIP) calcd. for $\mathrm{C}_{24} \mathrm{H}_{24} \mathrm{~N}_{2} \mathrm{O}_{2}$ : 372.1838; found: 372.1828 .

(3a $\left.S^{*}, 4 S^{*}, 9 \mathrm{a} R^{*}, 9 \mathrm{~b} R^{*}\right)$-2-Methyl-4-[(E)-styryl]octahydro-1Hpyrrolo[3,4-a]indolizine-1,3(2H)-dione (endo-15) $\left(3 \mathrm{a} R^{*}, 4 R^{*}, 9 \mathrm{a} R^{*}, 9 \mathrm{~b} S^{*}\right)-2-M e t h y l-4-[(E)$-styryl]octahydro-1Hpyrrolo[3,4- $a$ ]indolizine-1,3(2H)-dione (exo'-15)

Yield: $57 \mathrm{mg}$ (59\%), brown sticky oil.

IR (neat): 2938, 1697, 1433, 1382, 1281, 1239, 1138, 1039, 965, 749, $694 \mathrm{~cm}^{-1}$.

${ }^{1} \mathrm{H}-\mathrm{NMR}: \delta$ (mixture of endo:exo' $\left.1: 0.9\right)=1.11-1.28(\mathrm{~m}$, endo- $2 \mathrm{H}$, $\mathrm{NCHCH}_{2}$, exo'-1H, $\left.\mathrm{NCHCH}_{2}\right), 1.34-1.45\left(\mathrm{~m}\right.$, endo- $1 \mathrm{H}, \mathrm{NCH}_{2} \mathrm{CH}_{2}$, exo'- $1 \mathrm{H}$, $\left.\mathrm{NCHCH}_{2}\right), 1.50-1.66\left(\mathrm{~m}\right.$, endo- $1 \mathrm{H}, \mathrm{NCH}_{2} \mathrm{CH}_{2}$, exo'- $\left.1 \mathrm{H}, \mathrm{NCH}_{2} \mathrm{CH}_{2}\right), 1.69-$ 1.90 (m, endo- $1 \mathrm{H}, \mathrm{NCH}_{2} \mathrm{CH}_{2} \mathrm{CH}_{2}$, exo'- $2 \mathrm{H}, \mathrm{NCH}_{2} \mathrm{CH}_{2} \mathrm{CH}_{2}, \mathrm{CH}_{2} \mathrm{CH}_{2}$ ), 1.97$2.12\left(\mathrm{~m}\right.$, endo- $1 \mathrm{H}, \mathrm{NCH}_{2} \mathrm{CH}_{2} \mathrm{CH}_{2}$, exo'- $\left.1 \mathrm{H}, \mathrm{NCH}_{2} \mathrm{CH}_{2} \mathrm{CH}_{2}\right), 2.18-2.36$ (m, $J=$ $\mathrm{m}$, endo- $1 \mathrm{H}, \mathrm{NCH}_{2}$, exo'-1 $\left.\mathrm{H}, \mathrm{NCH}_{2}\right), 2.79-2.93\left(\mathrm{~m}\right.$, endo- $2 \mathrm{H}, \mathrm{NCHCH}_{2}$, $\mathrm{NCH}_{2}$, exo'- $\left.1 \mathrm{H}, \mathrm{NCHCH}_{2}\right), 2.98-3.02\left(\mathrm{~m}\right.$, endo-3H, $\mathrm{NCH}_{3}$, exo'-4H, $\mathrm{NCH}_{3}$, $\mathrm{NCHCH}), 3.03-3.08\left(\mathrm{~m}\right.$, endo- $1 \mathrm{H}, \mathrm{NCHCH}$ exo'-1H, $\left.\mathrm{NCH}_{2}\right), 3.10-3.32(\mathrm{~m}$, endo- $1 \mathrm{H}, \mathrm{CH}_{2} \mathrm{CHCH}$, exo'- $\left.2 \mathrm{H}, \mathrm{NCHCH}, \mathrm{CH}_{2} \mathrm{CHCH}\right), 4.13(\mathrm{~d}, J=9.6 \mathrm{~Hz}$, endo$1 \mathrm{H}, \mathrm{NCHCH}), 6.12$ (dd, $J=15.7,9.2 \mathrm{~Hz}$, exo'-1H, PhCHCH), 6.26 (dd, $J=$ 15.7, 9.6 Hz, endo- $1 \mathrm{H}, \mathrm{PhCHCH}), 6.61(\mathrm{~d}, J=15.7 \mathrm{~Hz}$, exo'-1H, $\mathrm{PhCH}), 6.64$ (d, $J=15.7 \mathrm{~Hz}$, endo- $1 \mathrm{H}, \mathrm{PhCH}), 7.46-7.21(\mathrm{~m}$, endo- $5 \mathrm{H}$, exo'- $5 \mathrm{H}, \mathrm{ArH})$.

${ }^{13} \mathrm{C}-\mathrm{NMR}: \delta$ (mixture of endo:exo') $=24.4,24.4\left(2 \mathrm{xNCH}_{2} \mathrm{CH}_{2} \mathrm{CH}_{2}\right), 24.8$, $25.0\left(2 \mathrm{xNCH}_{2} \mathrm{CH}_{2}\right), 25.0,25.1\left(2 \mathrm{xNCH}_{3}\right), 28.0,28.9\left(2 \mathrm{xNCHCH}_{2}\right), 47.1$, 47.6, 48.2 (3xCHCO), $48.5\left(\mathrm{NCH}_{2}\right), 50.0(\mathrm{CHCO}), 51.8\left(\mathrm{NCH}_{2}\right), 60.5,65.9$, $67.8,70.5(4 \times \mathrm{NCH}), 125.0,126.5,126.8,127.9,128.0,128.2,128.6,128.7$, 134.3, 134.5, 136.3, $136.7(\operatorname{ArC}, 2 \times C=C), 176.4,176.7,176.9,178.7$ $(4 \times C O)$.

MS (EI): $m / z=310\left(\mathrm{M}^{+}, 18 \%\right), 309$ (17), 220 (14), 219 (100), 199 (20), 198 (17), 115 (10).

HRMS (DIP) calcd. for $\mathrm{C}_{19} \mathrm{H}_{22} \mathrm{~N}_{2} \mathrm{O}_{2}: 310.1681$; found: 310.1668 .

$\left(3 \mathrm{a} R^{*}, 4 S^{*}, 9 \mathrm{a} R^{*}, 9 \mathrm{~b} S^{*}\right)-2-M e t h y l-4-[(E)$-styryl] $]$ octahydro-1Hpyrrolo[3,4-a]indolizine-1,3(2H)-dione (exo-15)

Yield: $21 \mathrm{mg}(22 \%)$, yellow sticky oil.

IR (neat): 2919, 2850, 1698, 1435, 1283, 1122, 1074, 1010, 966, 732, $694 \mathrm{~cm}^{-1}$.

${ }^{1} \mathrm{H}-\mathrm{NMR}: \delta=1.21-1.30\left(\mathrm{~m}, 1 \mathrm{H}, \mathrm{NCHCH} \mathrm{H}_{2}\right), 1.44-1.53\left(\mathrm{~m}, 4 \mathrm{H}, \mathrm{NCH}_{2} \mathrm{CH}_{2}\right.$, $\left.\mathrm{NCHCH}_{2}\right), 1.55-1.69\left(\mathrm{~m}, 1 \mathrm{H}, \mathrm{NCH}_{2} \mathrm{CH}_{2}\right), 1.78-1.89\left(\mathrm{~m}, 2 \mathrm{H}, \mathrm{NCH}_{2} \mathrm{CH}_{2} \mathrm{CH}_{2}\right)$, 2.62-2.75 (m, $\left.1 \mathrm{H}, \mathrm{NCH}_{2}\right), 2.88\left(\mathrm{dd}, J=8.2,2.1 \mathrm{~Hz}, 1 \mathrm{H}, \mathrm{CH}_{2} \mathrm{CHCH}\right), 2.91-$ $2.98\left(\mathrm{~m}, 1 \mathrm{H}, \mathrm{NCH}_{2}\right), 3.00\left(\mathrm{~s}, 1 \mathrm{H}, \mathrm{NCH}_{3}\right), 3.38(\mathrm{dd}, J=8.2,8.0 \mathrm{~Hz}, 1 \mathrm{H}$, NCHCHCO), $3.44-3.51\left(\mathrm{~m}, 1 \mathrm{H}, \mathrm{NCH}_{2}\right), 4.10(\mathrm{dd}, J=9.5,8.0 \mathrm{~Hz}, 1 \mathrm{H}$, NCHCHCO), 5.93 (dd, $J=15.7,9.5 \mathrm{~Hz}, 1 \mathrm{H}, \mathrm{PhCHCH}), 6.64(\mathrm{~d}, J=15.7 \mathrm{~Hz}$, $1 \mathrm{H}, \mathrm{PhCH}), 7.23-7.42(\mathrm{~m}, 5 \mathrm{H}, \mathrm{Ar} H)$.

${ }^{13} \mathrm{C}-\mathrm{NMR}: \delta=19.2\left(\mathrm{NCH}_{2} \mathrm{CH}_{2} \mathrm{CH}_{2}\right), 24.5\left(\mathrm{NCH}_{2} \mathrm{CH}_{2}\right), 25.2\left(\mathrm{NCH}_{3}\right), 27.0$ $\left(\mathrm{NCHCH}_{2}\right), 45.5\left(\mathrm{NCH}_{2}\right), 48.7$ ( $\left.\mathrm{NCHCHCO}\right), 50.5$ ( $\left.\mathrm{NCHCHCO}\right), 62.1,62.1$ $(2 \times \mathrm{NCH}), 126.5,126.8,127.9,128.6,134.6,136.6(\mathrm{ArC}, \mathrm{C}=\mathrm{C}), 176.5,178.8$ $(2 \times \mathrm{NCO})$.

MS (EI): $m / z=310\left(\mathrm{M}^{+}, 18 \%\right), 309$ (16), 220 (14), 219 (100), 199 (9), $198(12), 115$ (9).

HRMS (DIP) calcd for $\mathrm{C}_{19} \mathrm{H}_{22} \mathrm{~N}_{2} \mathrm{O}_{2}$ : 310.1681; found: 310.1668 .

(3aS*,4S*,9aR*,9b $R^{*}$ )-2-Phenyl-4-[(E)-styryl]octahydro-1Hpyrrolo[3,4-a]indolizine-1,3(2H)-dione (endo-16)

Yield: $31 \mathrm{mg}(27 \%)$, yellow sticky oil.

IR (neat): 2941, 1708, 1498, 1381, 1185, 968, 849, $734 \mathrm{~cm}^{-1}$.

${ }^{1} \mathrm{H}-\mathrm{NMR}: \quad \delta=1.15-1.29\left(\mathrm{~m}, 2 \mathrm{H}, \mathrm{NCHCH}_{2} \mathrm{CH}_{2}\right), 1.38-1.47(\mathrm{~m}, 1 \mathrm{H}$, $\left.\mathrm{NCH}_{2} \mathrm{CH}_{2}\right), 1.54-1.63\left(\mathrm{~m}, 1 \mathrm{H}, \mathrm{NCH}_{2} \mathrm{CH}_{2}\right), 1.77-1.85\left(\mathrm{~m}, 1 \mathrm{H}, \mathrm{NCH}_{2} \mathrm{CH}_{2} \mathrm{CH}_{2}\right)$, 2.02-2.13 (m, $\left.1 \mathrm{H}, \mathrm{NCH}_{2} \mathrm{CH}_{2} \mathrm{CH}_{2}\right), 2.34\left(\mathrm{td}, J=11.5,3.0 \mathrm{~Hz}, 1 \mathrm{H}, \mathrm{NCH}_{2}\right)$, $2.85-2.92\left(\mathrm{~m}, 1 \mathrm{H}, \mathrm{NCH}_{2}\right), 2.96$ (ddd, $\left.J=10.8,8.4,2.7 \mathrm{~Hz}, 1 \mathrm{H}, \mathrm{NCHCH}_{2}\right)$, $3.22(\mathrm{dd}, J=7.9,0.8 \mathrm{~Hz}, 1 \mathrm{H}, \mathrm{NCHCHCO}), 3.43(\mathrm{dd}, J=8.4,7.9 \mathrm{~Hz}, 1 \mathrm{H}$, $\mathrm{CH}_{2} \mathrm{CHCH}$ ), 4.25 (d, $\left.J=9.5 \mathrm{~Hz}, 1 \mathrm{H}, \mathrm{NCHCHCO}\right), 6.30(\mathrm{dd}, J=15.7,9.5 \mathrm{~Hz}$, 1H, PhCHCH), 6.67 (d, J = 15.7 Hz, 1H, PhCH), 7.19-7.52 (m, 10H, ArH).

${ }^{13} \mathrm{C}-\mathrm{NMR}: \delta=24.5\left(\mathrm{NCH}_{2} \mathrm{CH}_{2} \mathrm{CH}_{2}\right), 25.2\left(\mathrm{NCH}_{2} \mathrm{CH}_{2}\right), 29.3\left(\mathrm{NCHCH}_{2}\right), 47.6$ ( $\mathrm{NCHCHCO}), 48.6\left(\mathrm{NCH}_{2}\right), 50.2(\mathrm{NCHCHCO}), 60.8(\mathrm{NCH}), 68.2(\mathrm{NCH})$, 124.8, 126.2, 126.9, 128.1, 128.6, 128.8, 129.1, 132.3, 134.4, 136.4 (ArC, $C=C), 176.0,177.8(2 \times N C O)$.

MS (EI): $m / z=372\left(\mathrm{M}^{+}, 23 \%\right), 371$ (16), 282 (19), 281 (100), 199 (32), $198(18), 115(10)$. $\left(3 \mathrm{a} R^{*}, 4 S^{*}, 9 \mathrm{a} R^{*}, 9 \mathrm{~b} S^{*}\right)-2$-Phenyl-4-[(E)-styryl]octahydro-1Hpyrrolo[3,4-a]indolizine-1,3(2H)-dione (exo-16)

Yield: $17 \mathrm{mg}(15 \%)$, prisms, $\mathrm{mp} 133-137^{\circ} \mathrm{C}\left(\mathrm{Et}_{2} \mathrm{O}\right)$.

IR (neat): 2930, 1705, 1498, 1384, 1189, 974, $749 \mathrm{~cm}^{-1}$.

${ }^{1} \mathrm{H}-\mathrm{NMR}: \delta=1.25-1.34\left(\mathrm{~m}, 2 \mathrm{H}, \mathrm{NCHCH}_{2}\right), 1.46-1.62\left(\mathrm{~m}, 2 \mathrm{H}, \mathrm{NCH}_{2} \mathrm{CH}_{2}\right.$ ), $1.69-1.76\left(\mathrm{~m}, 1 \mathrm{H}, \mathrm{NCH}_{2} \mathrm{CH}_{2} \mathrm{CH}_{2}\right), 1.79-1.95\left(\mathrm{~m}, 1 \mathrm{H}, \mathrm{NCH}_{2} \mathrm{CH}_{2} \mathrm{CH}_{2}\right), 2.66-$ $2.79\left(\mathrm{~m}, 1 \mathrm{H}, \mathrm{NCH}_{2}\right), 2.93-3.02\left(\mathrm{~m}, 1 \mathrm{H}, \mathrm{NCHCH}_{2}\right), 3.06(\mathrm{dd}, J=8.4,2.4 \mathrm{~Hz}$, $\left.1 \mathrm{H}, \mathrm{CH}_{2} \mathrm{CHCH}\right), 3.56(\mathrm{dd}, J=8.4,8.2 \mathrm{~Hz}, 1 \mathrm{H}, \mathrm{NCHCHCO}), 3.53-3.59(\mathrm{~m}, 1 \mathrm{H}$, $\mathrm{NCH}_{2}$ ), 4.21 (dd, $\left.J=9.1,8.2 \mathrm{~Hz}, 1 \mathrm{H}, \mathrm{NCHCHCO}\right), 6.05(\mathrm{dd}, J=15.7,9.1 \mathrm{~Hz}$, $1 \mathrm{H}, \mathrm{PhCHCH}), 6.69(\mathrm{~d}, J=15.7 \mathrm{~Hz}, 1 \mathrm{H}, \mathrm{PhCH}), 7.23-7.46(\mathrm{~m}, 10 \mathrm{H}, \mathrm{Ar} H)$.

${ }^{13} \mathrm{C}-\mathrm{NMR}: \delta=19.7\left(\mathrm{NCH}_{2} \mathrm{CH}_{2} \mathrm{CH}_{2}\right), 24.5\left(\mathrm{NCH}_{2} \mathrm{CH}_{2}\right), 27.4\left(\mathrm{NCHCH}_{2}\right), 45.8$ $\left(\mathrm{NCH}_{2}\right), 48.7$ ( $\left.\mathrm{NCHCHCO}\right), 50.6$ ( $\left.\mathrm{NCHCHCO}\right), 62.5(\mathrm{NCH}), 62.8(\mathrm{NCH})$, 125.9, 126.6, 126.9, 128.0, 128.6, 128.7, 129.2, 132.1, 134.7, 136.6 (ArC, $C=C), 175.5,177.8\left(2 \times N_{C O}\right)$.

MS (EI): $m / z=372\left(M^{+}, 23 \%\right), 371$ (13), 282 (19), 281 (100), 199 (15), 198 (14).

HRMS (DIP) calcd. for $\mathrm{C}_{24} \mathrm{H}_{24} \mathrm{~N}_{2} \mathrm{O}_{2}: 372.1838$; found: 372.1828 .

Dimethyl $\left(1 S^{*}, 2 S^{*}, 3 S^{*}, 8 \mathrm{a} R^{*}\right)-3-[(E)$-styryl $]$ octahydroindolizine-1,2dicarboxylate (endo-17) and dimethyl $\left(1 R^{*}, 2 R^{*}, 3 R^{*}, 8 \mathrm{a} R^{*}\right)-3-[(E)-$ styryl]octahydroindolizine-1,2-dicarboxylate (exo'-17)

Yield: $37 \mathrm{mg}$ (35\%), yellow oil.

IR (neat): 2934, 2853, 1733, 1436, 1300, 1196, 1168, 1011, 968, 749, $693 \mathrm{~cm}^{-1}$.

${ }^{1} \mathrm{H}$-NMR: $\delta$ (mixture of endo:exo' 1:0.75, difficult assignment) $=1.04-1.41$ $(\mathrm{m}, 4 \mathrm{H}), 1.49(\mathrm{tt}, J=7.1,3.6 \mathrm{~Hz}, 3 \mathrm{H}), 1.64-1.71(\mathrm{~m}, 1 \mathrm{H}), 1.78(\mathrm{td}, J=9.2$, 7.4, 4.2 Hz, 2H), 1.87-1.96 (m, 1H), 2.36-2.50 (m, 2H), 2.80-2.96 (m, 3H), 3.08 (dd, $J=7.8,7.1 \mathrm{~Hz}, 1 \mathrm{H}$ ), 3.15 (ddd, $J=11.5,8.9,2.9 \mathrm{~Hz}, 1 \mathrm{H}$ ), 3.27 (dd, $J=7.1,4.2 \mathrm{~Hz}, 1 \mathrm{H}), 3.55(\mathrm{~s}, 2 \mathrm{H}), 3.71(\mathrm{~s}, J=1.0 \mathrm{~Hz}, 5 \mathrm{H}), 3.75(\mathrm{~s}, 2 \mathrm{H}), 3.88$ $(\mathrm{t}, J=8.1 \mathrm{~Hz}, 1 \mathrm{H}), 4.03-4.15(\mathrm{~m}, 2 \mathrm{H}), 6.09(\mathrm{dd}, J=15.7,9.8 \mathrm{~Hz}, 1 \mathrm{H}), 6.28$ (dd, $J=15.7,9.5 \mathrm{~Hz}, 1 \mathrm{H}), 6.54(\mathrm{~d}, J=15.7 \mathrm{~Hz}, 1 \mathrm{H}), 6.57(\mathrm{~d}, J=15.7 \mathrm{~Hz}$, 1H), 7.22-7.35 (m, 7H), 7.36-7.42 (m, 2H).

${ }^{13} \mathrm{C}$-NMR: $\delta$ (mixture of endo:exo', difficult assignment) $=23.4,23.7,24.0$, 24.3, 27.3, 30.5, 47.6, 48.0, 48.1, 49.4, 51.5, 51.9, 52.0, 52.3, 52.3, 61.3, $63.3,66.3,67.2,124.8,126.6,127.8,127.8,128.4,132.2,134.7,136.6$, $172.2,173.1,173.7,173.8$.

MS (EI): $m / z=343\left(\mathrm{M}^{+}, 33 \%\right), 284$ (35), 282 (19), 253 (15), 252 (100), 250 (17), 199 (39), 198 (24), 115 (17).

HRMS (DIP) calcd. for $\mathrm{C}_{20} \mathrm{H}_{25} \mathrm{NO}_{4}$ : 343.1784 ; found: 343.1785 .

Dimethyl $\left(1 S^{*}, 2 S^{*}, 3 R^{*}, 8 \mathrm{a} R^{*}\right)-3-((E)$-styryl)octahydroindolizine-1,2dicarboxylate (endo'-17) and Dimethyl $(1 R, 2 R, 3 S, 8 \mathrm{a} R)-3-[(E)-$ styryl]octahydroindolizine-1,2-dicarboxylate (exo-17)

Yield: $43 \mathrm{mg}$ (40\%), yellow oil.

IR (neat): 2944, 2854, 1733, 1436, 1196, 1167, 1005, 969, 746, $693 \mathrm{~cm}^{-1}$.

${ }^{1} \mathrm{H}$-NMR: $\delta$ (mixture of endo'exo 0.65:1, difficult assignment) $=1.06-1.25$ $(\mathrm{m}, 2 \mathrm{H}), 1.43(\mathrm{tdd}, J=12.4,10.8,3.6 \mathrm{~Hz}, 2 \mathrm{H}), 1.58(\mathrm{q}, J=3.4 \mathrm{~Hz}, 2 \mathrm{H})$, $1.76-1.91(\mathrm{~m}, 4 \mathrm{H}), 1.98-2.07(\mathrm{~m}, 1 \mathrm{H}), 2.19(\mathrm{td}, J=10.4,2.5 \mathrm{~Hz}, 1 \mathrm{H}), 2.43$ (ddd, $J=10.8,8.3,2.3 \mathrm{~Hz}, 1 \mathrm{H}), 2.95-3.05(\mathrm{~m}, 1 \mathrm{H}), 3.12(\mathrm{~d}, J=10.9 \mathrm{~Hz}$, $1 \mathrm{H}), 3.18-3.32(\mathrm{~m}, 3 \mathrm{H}), 3.37$ (dd, $J=8.5,4.9 \mathrm{~Hz}, 1 \mathrm{H}), 3.43(\mathrm{dd}, J=10.0$, $7.8 \mathrm{~Hz}, 1 \mathrm{H}), 3.59(\mathrm{~s}, 3 \mathrm{H}), 3.66(\mathrm{~s}, 2 \mathrm{H}), 3.70(\mathrm{~s}, 3 \mathrm{H}), 3.73(\mathrm{~s}, 2 \mathrm{H}), 5.95(\mathrm{dd}, J$ $=15.8,8.6 \mathrm{~Hz}, 1 \mathrm{H}), 6.21(\mathrm{dd}, J=15.8,8.5 \mathrm{~Hz}, 1 \mathrm{H}), 6.55(\mathrm{dd}, J=15.8 \mathrm{~Hz}$ $1 \mathrm{H}), 6.57(\mathrm{dd}, J=15.8 \mathrm{~Hz}, 1 \mathrm{H}), 7.16-7.45(\mathrm{~m}, 9 \mathrm{H})$.

${ }^{13} \mathrm{C}$-NMR: $\delta$ (mixture of endo':exo, difficult assignment) $=24.0,24.3,24.7$, $24.9,28.4,30.5,49.5,49.8,50.7,51.2,51.2,51.7,51.9,51.9,52.0,52.1$, $66.4,66.7,69.3,72.0,126.5,126.6,127.2,127.7,127.8,128.6,128.6$, $129.1,134.0,134.1,136.7,173.8,173.1,173.3,173.8$.

MS (EI): $m / z=343\left(\mathrm{M}^{+}, 34 \%\right), 284$ (36), 253 (15), 252 (100), 199 (66), 198 (36), 192 (12), 157 (13), 156 (13), 122 (13), 115 (18).

HRMS (DIP) calcd. for $\mathrm{C}_{20} \mathrm{H}_{25} \mathrm{NO}_{4}$ : 343.1784 ; found: 343.1785 . 
Diisobutyl $\left(1 S^{*}, 2 S^{*}, 3 S^{*}, 8 \mathrm{a} R^{*}\right)$-3-[(E)-styryl]octahydroindolizine-1,2dicarboxylate (endo-18) and diisobutyl $\left(1 R^{*}, 2 R^{*}, 3 R^{*}, 8 \mathrm{a} R^{*}\right)-3-[(E)$ styryl]octahydroindolizine-1,2-dicarboxylate (exo'-18)

Yield: $49 \mathrm{mg}$ (37\%), yellow oil.

IR (neat): 2961, 2935, 1731, 1469, 1379, 1169, 1002, 967, 748, $693 \mathrm{~cm}^{-1}$. ${ }^{1} \mathrm{H}$-NMR: $\delta$ (mixture of endo:exo' 1:0.5, difficult assignment) $=0.79(\mathrm{~s}$, $1 \mathrm{H}), 0.80(\mathrm{~s}, 1 \mathrm{H}), 0.82(\mathrm{~s}, 1 \mathrm{H}), 0.83(\mathrm{~s}, 1 \mathrm{H}), 0.90(\mathrm{~s}, 3 \mathrm{H}), 0.92(\mathrm{~s}, 3 \mathrm{H}), 0.94$ (s, 3H), $0.96(\mathrm{~s}, 3 \mathrm{H}), 1.07-1.15(\mathrm{~m}, 1 \mathrm{H}), 1.16-1.29(\mathrm{~m}, 2 \mathrm{H}), 1.41-1.31(\mathrm{~m}$, $1 \mathrm{H}), 1.48(\mathrm{dtt}, J=9.2,6.3,3.6 \mathrm{~Hz}, 2 \mathrm{H}), 1.69(\mathrm{dd}, J=12.1,3.3 \mathrm{~Hz}, 0 \mathrm{H})$, $1.73-1.87(\mathrm{~m}, 1 \mathrm{H}), 1.89-2.03(\mathrm{~m}, 2 \mathrm{H}), 2.36-2.53(\mathrm{~m}, 1 \mathrm{H}), 2.78-2.96(\mathrm{~m}$ $2 \mathrm{H}), 3.07(\mathrm{t}, J=7.7 \mathrm{~Hz}, 1 \mathrm{H}), 3.16(\mathrm{ddd}, J=11.3,8.8,2.8 \mathrm{~Hz}, 1 \mathrm{H}), 3.27(\mathrm{dd}, J$ $=7.4,4.3 \mathrm{~Hz}, 1 \mathrm{H}), 3.62-3.81(\mathrm{~m}, 1 \mathrm{H}), 3.82-3.99(\mathrm{~m}, 4 \mathrm{H}), 4.03-4.19(\mathrm{~m}$, $1 \mathrm{H}), 6.09(\mathrm{dd}, J=15.7,9.8 \mathrm{~Hz}, 1 \mathrm{H}), 6.30(\mathrm{dd}, J=15.7,9.5 \mathrm{~Hz}, 1 \mathrm{H}), 6.52(\mathrm{~d}$, $J=15.6, \mathrm{~Hz}, 1 \mathrm{H}), 6.57$ (d, $J=15.7, \mathrm{~Hz}, 1 \mathrm{H}), 7.16-7.47$ (m, 8H).

${ }^{13} \mathrm{C}$-NMR: $\delta$ (mixture of endo:exo' 1:0.5, difficult assignement) $=19.1$, $19.2,19.3,23.9,24.0,24.4,27.3,27.7,27.8,27.9,30.6,47.7,47.9,48.2$, $49.4,51.8,52.7,61.3,63.4,66.2,67.2,71.1,71.2,125.1,126.6,127.7$ 127.8, 128.6, 128.8, 129.2, 133.1, 134.6, 136.6, 136.7, 171.9, 172.8, 173.3. MS (EI): $m / z=427\left(\mathrm{M}^{+}, 27 \%\right), 354$ (15), 337 (22), $336(100), 326$ (39), 324 (13), 224 (22), 199 (38), 198 (21), 122 (15).

HRMS (DIP) calcd. for $\mathrm{C}_{26} \mathrm{H}_{37} \mathrm{NO}_{4}$ : 427.2723; found: 427.2720 .

Diisobutyl $\quad\left(1 S^{*}, 2 S^{*}, 3 R^{*}, 8 \mathrm{a} R^{*}\right)-3-[(E)$-styryl]octahydroindolizine1,2-dicarboxylate (endo'-18) and diisobutyl $\left(1 R^{*}, 2 R^{*}, 3 S^{*}, 8 \mathrm{a} R^{*}\right)-3$ [(E)-styryl]octahydroindolizine-1,2-dicarboxylate (exo-18)

Yield: $50 \mathrm{mg}$ (38\%), yellow oil.

IR (neat): 2960, 1729, 1469, 1383, 1168, 1002, 968, 738, $692 \mathrm{~cm}^{-1}$.

${ }^{1} \mathrm{H}$-NMR: $\delta$ (mixture of endo':exo 0.65:1 difficult assignment) $=0.74(\mathrm{~s}$, $1 \mathrm{H}), 0.75(\mathrm{~s}, 1 \mathrm{H}), 0.76(\mathrm{~s}, 1 \mathrm{H}), 0.77(\mathrm{~s}, 1 \mathrm{H}), 0.85(\mathrm{~d}, J=0.8 \mathrm{~Hz}, 2 \mathrm{H}), 0.87$ (d, $J=0.8 \mathrm{~Hz}, 2 \mathrm{H}), 0.92(\mathrm{~d}, J=0.6 \mathrm{~Hz}, 3 \mathrm{H}), 0.94(\mathrm{~d}, J=0.6 \mathrm{~Hz}, 3 \mathrm{H}), 0.95$ (s, $2 \mathrm{H}), 0.97(\mathrm{~s}, 2 \mathrm{H}), 1.12-1.31(\mathrm{~m}, 2 \mathrm{H}), 1.37-1.67(\mathrm{~m}, 3 \mathrm{H}), 1.71-2.03(\mathrm{~m}$, $7 \mathrm{H}), 2.04-2.11(\mathrm{~m}, 1 \mathrm{H}), 2.20$ (td, $J=10.4,2.5 \mathrm{~Hz}, 1 \mathrm{H}), 2.43$ (ddd, $J=10.7$, 8.2, $2.4 \mathrm{~Hz}, 1 \mathrm{H}), 2.92-3.07(\mathrm{~m}, 1 \mathrm{H}), 3.11(\mathrm{~d}, J=10.9 \mathrm{~Hz}, 1 \mathrm{H}), 3.18-3.48$ (m, 4H), 3.69-3.82 (m, 2H), 3.84-3.95 (m, 4H), 5.97 (dd, $J=15.8,8.7 \mathrm{~Hz}$, $1 \mathrm{H}), 6.22(\mathrm{dd}, J=15.8,8.5 \mathrm{~Hz}, 1 \mathrm{H}), 6.55(\mathrm{~d}, J=15.8 \mathrm{~Hz}, 1 \mathrm{H}), 6.56(\mathrm{~d}, J=$ $15.8 \mathrm{~Hz}, 1 \mathrm{H}), 7.20-7.43(\mathrm{~m}, 8 \mathrm{H})$.

${ }^{13} \mathrm{C}$-NMR: $\delta$ (mixture of endo':exo, 0.65:1 difficult assignment) $=19.1$, 19.2, 19.3, 24.1, 24.4, 24.8, 25.0, 27.6, 27.7, 27.8, 28.6, 30.6, 49.5, 49.9, 50.9, 51.2, 51.4, 51.7, 66.5, 66.6, 69.3, 71.0, 71.1, 71.2, 72.0, 126.6, 127.4, $127.7,128.6,129.6,133.9,134.1,136.7,136.8,172.5,172.9,173.5$.

MS (EI): $m / z=427\left(\mathrm{M}^{+}, 34 \%\right), 354$ (23), 337 (22), 336 (100), 326 (47), 252 (17), 224 (24), 199 (80), 198 (35), 122 (17).

HRMS (DIP) calcd. for $\mathrm{C}_{26} \mathrm{H}_{37} \mathrm{NO}_{4}$ : 427.2723; found: 427.2720.

tert-Butyl $\quad\left(2 S^{*}, 3 S^{*}, 8 \mathrm{a} R^{*}\right)-3-[(E)$-styryl]octahydroindolizine-2carboxylate (endo-19)

Yield: $20 \mathrm{mg}$ (19\%), yellow sticky oil.

IR (neat): 2931, 1723, 1366, 1148, $966 \mathrm{~cm}^{-1}$.

${ }^{1} \mathrm{H}$-NMR: $\delta=1.23-1.39\left(\mathrm{~m}, 2 \mathrm{H}, \mathrm{NCHCH}_{2} \mathrm{CH}_{2}\right), 1.43(\mathrm{~s}, 9 \mathrm{H}, t-\mathrm{Bu}), 1.47-1.78$ (m, 5H, $\mathrm{CH}_{2} \mathrm{CHCO}_{2}, \mathrm{NCH}_{2} \mathrm{CH}_{2}, \mathrm{NCH}_{2} \mathrm{CH}_{2} \mathrm{CH}_{2}$ ), 2.28 (ddd, $J=12.5,10.3,6.3$ $\mathrm{Hz}, 1 \mathrm{H}, \mathrm{CH}_{2} \mathrm{CHCO}_{2}$ ), 2.58 (td, $J=12.3,3.3 \mathrm{~Hz}, 1 \mathrm{H}, \mathrm{NCH}_{2}$ ), 2.72 (ddd, $J=$ $\left.10.3,7.4,5.9 \mathrm{~Hz}, 1 \mathrm{H}, \mathrm{CHCO}_{2}\right), 2.86-3.01\left(\mathrm{~m}, 2 \mathrm{H}, \mathrm{NCHCH}_{2}, \mathrm{NCH}_{2}\right), 3.98$ (dd, $J=9.2,5.9 \mathrm{~Hz}, 1 \mathrm{H}, \mathrm{NCH}), 6.17(\mathrm{dd}, J=15.7,9.2 \mathrm{~Hz}, 1 \mathrm{H}, \mathrm{PhCHCH}), 6.54(\mathrm{~d}, J$ $=15.7 \mathrm{~Hz}, 1 \mathrm{H}, \mathrm{PhCH}), 7.18-7.43(\mathrm{~m}, 5 \mathrm{H}, \mathrm{ArH})$.

${ }^{13} \mathrm{C}$-NMR: $\delta=22.4\left(\mathrm{NCH}_{2} \mathrm{CH}_{2} \mathrm{CH}_{2}\right), 24.4\left(\mathrm{NCH}_{2} \mathrm{CH}_{2}\right), 28.3\left(\mathrm{CH}_{3}\right), 29.9$ $\left(\mathrm{NCHCH}_{2} \mathrm{CH}_{2}\right), 34.7\left(\mathrm{CH}_{2} \mathrm{CHCO}_{2} \mathrm{t}-\mathrm{Bu}\right), 46.8\left(\mathrm{NCH}_{2}\right), 49.6\left(\mathrm{CHCO} \mathrm{CH}_{2} \mathrm{t}-\mathrm{Bu}\right)$, $59.8(\mathrm{NCH}), 66.0(\mathrm{NCH}), 80.6\left(\mathrm{CMe}_{3}\right), 126.5,127.6,128.7,130.3,132.7$, $137.0(\mathrm{ArC}, C=C), 174.0(\mathrm{CO})$.

MS (EI): $m / z=327\left(\mathrm{M}^{+}, 18 \%\right), 271$ (27), 270 (100), 254 (16), 226 (18), $180(74)$.

HRMS (DIP) calcd. for $\mathrm{C}_{21} \mathrm{H}_{29} \mathrm{NO}_{2}: 327.2198$; found: 327.2199.
IR (neat): 2938, 2855, 1717, 1549, 1496, 1449, 1362, 1264, 1144, 967, $736,694 \mathrm{~cm}^{-1}$.

${ }^{1} \mathrm{H}-\mathrm{NMR}: \delta=1.25-1.36\left(\mathrm{~m}, 2 \mathrm{H}, \mathrm{NCHCH}_{2}\right), 1.51-1.62\left(\mathrm{~m}, 1 \mathrm{H}, \mathrm{NCHCHCH}_{2}\right)$, $1.70-1.78\left(\mathrm{~m}, 1 \mathrm{H}, \mathrm{NCHCHCH}_{2}\right), 1.84-1.93\left(\mathrm{~m}, 2 \mathrm{H}, \mathrm{NCHCHCH}_{2}\right), 2.44$ (ddd, $\left.J=11.9,8.9,6.5 \mathrm{~Hz}, 1 \mathrm{H}, \mathrm{NCH}_{2}\right), 2.90-3.03\left(\mathrm{~m}, 1 \mathrm{H}, \mathrm{NCH}_{2}\right), 3.30-3.42(\mathrm{~m}$, $\left.1 \mathrm{H}, \mathrm{NCHCH}_{2}\right), 4.25$ (dd, $\left.J=10.1,7.8 \mathrm{~Hz}, 1 \mathrm{H}, \mathrm{NCHCHPh}\right), 4.59$ (dd, $J=7.8$, $7.2 \mathrm{~Hz}, 1 \mathrm{H}, \mathrm{NCHCHPh}), 5.54\left(\mathrm{dd}, J=8.4,7.2 \mathrm{~Hz}, 1 \mathrm{H}, \mathrm{CHNO}_{2}\right), 5.89(\mathrm{dd}, J=$ 15.6, 10.1 Hz, 1H, PhCHCH), 6.32 (d, $J=15.6 \mathrm{~Hz}, 1 \mathrm{H}, \mathrm{PhCH}), 7.06-7.38(\mathrm{~m}$, $10 \mathrm{H}, \mathrm{Ar} H$ ).

${ }^{13} \mathrm{C}$-NMR: $\delta=23.8\left(\mathrm{NCH}_{2} \mathrm{CH}_{2} \mathrm{CH}_{2}\right), 23.9\left(\mathrm{NCH}_{2} \mathrm{CH}_{2}\right), 26.0\left(\mathrm{NCHCH}_{2}\right), 48.4$ $\left(\mathrm{NCH}_{2}\right), 51.7(\mathrm{NCHCH}), 62.3(\mathrm{NCH}), 69.2(\mathrm{NCH}), 93.0\left(\mathrm{CNO}_{2}\right), 124.8$, $126.5,127.4,127.8,128.6,128.7,128.8,135.2,136.6,136.8(\operatorname{ArC} C, C=C)$.

MS (EI): $m / z=348\left(\mathrm{M}^{+}, 1 \%\right), 303$ (25), 302 (100), 300 (11), 257 (10), 219 (15), 143 (11), 117 (20), 115 (21).

HRMS (DIP) calcd. for $\mathrm{C}_{22} \mathrm{H}_{24} \mathrm{~N}_{2} \mathrm{O}_{2}$ : 348.1838; found: 348.1825 .

$\left(3 \mathrm{a} S^{*}, 4 R^{*}, 9 \mathrm{a} R^{*}, 9 \mathrm{~b} R^{*}\right)-2,4-D i p h e n y l o c t a h y d r o-1 \mathrm{H}-$ pyrrolo[3,4a] indolizine-1,3(2H)-dione (endo-21)

Yield: $58 \mathrm{mg}(54 \%)$, white solid, $\mathrm{mp} 151-154^{\circ} \mathrm{C}\left(\mathrm{Et}_{2} \mathrm{O}\right)$.

IR (neat): 2943, 2850, 1701, 1497, 1393, 1189, 848, 755, $693 \mathrm{~cm}^{-1}$.

${ }^{1} \mathrm{H}$-NMR: $\delta=0.89-1.12\left(\mathrm{~m}, 1 \mathrm{H}, \mathrm{NCH}_{2} \mathrm{CH}_{2} \mathrm{CH}_{2}\right), 1.11-1.29(\mathrm{~m}, 1 \mathrm{H}$, $\mathrm{NCH}_{2} \mathrm{CH}_{2} \mathrm{CH}_{2}$ ), $1.33-1.56$ (m, $\left.2 \mathrm{H}, \mathrm{NCHCH}_{2}\right), 1.60-1.84\left(\mathrm{~m}, 2 \mathrm{H}, \mathrm{NCH}_{2} \mathrm{CH}_{2}\right.$ ), $1.97-2.20\left(\mathrm{~m}, 1 \mathrm{H}, \mathrm{NCH}_{2}\right), 2.87$ (ddt, $J=14.5,6.4,2.7 \mathrm{~Hz}, 2 \mathrm{H}, \mathrm{NH}_{2}$, $\left.\mathrm{NCHCH}_{2}\right), 3.35-3.73\left(\mathrm{~m}, 2 \mathrm{H}, \mathrm{PhCHCH}, \mathrm{CH}_{2} \mathrm{CHCH}\right), 4.69(\mathrm{~d}, J=0.9 \mathrm{~Hz}, 1 \mathrm{H}$, $\mathrm{NCHPh}), 7.07-7.19(\mathrm{~m}, 2 \mathrm{H}, \mathrm{ArH}), 7.30-7.54(\mathrm{~m}, 8 \mathrm{H}, \mathrm{ArH})$.

${ }^{13} \mathrm{C}$-NMR: $\delta=24.2\left(\mathrm{NCH}_{2} \mathrm{CH}_{2} \mathrm{CH}_{2}\right), 24.9\left(\mathrm{NCH}_{2} \mathrm{CH}_{2}\right), 29.1\left(\mathrm{NCHCH}_{2}\right), 48.5$ $\left(\mathrm{NCH}_{2}\right), 48.7(\mathrm{NCHCHCO}), 50.3(\mathrm{NCHCHCO}), 59.9(\mathrm{NCH}), 69.4(\mathrm{NCH})$, $126.7,128.0,128.4,128.6,128.6,128.7,132.3$, $136.6(\operatorname{ArC}), 176.1,178.1$ (2xNCO).

MS (EI): $m / z=346\left(\mathrm{M}^{+}, 61 \%\right), 345$ (48), 269 (22), 198 (12), 173 (57), 172 (100), 115 (14).

HRMS (DIP) calcd. for $\mathrm{C}_{22} \mathrm{H}_{22} \mathrm{~N}_{2} \mathrm{O}_{2}$ : 346.1681; found: 346.1668 .

$\left(3 \mathrm{a} R^{*}, 4 R^{*}, 9 \mathrm{a} R^{*}, 9 \mathrm{~b} S^{*}\right)-2,4-D i p h e n y l o c t a h y d r o-1 \mathrm{H}-p y r r o l o[3,4-$ $a$ ] indolizine-1,3(2H)-dione (exo-21)

Yield: $26 \mathrm{mg}$ (24\%), yellow oil.

IR (neat): 2934, 2854, 1712, 1496, 1376, 1173, 734, $698 \mathrm{~cm}^{-1}$.

${ }^{1} \mathrm{H}$-NMR: $\delta=1.29-1.39\left(\mathrm{~m}, 2 \mathrm{H}, \mathrm{NCH}_{2} \mathrm{CH}_{2} \mathrm{CH}_{2}\right), 1.58-1.64(\mathrm{~m}, 1 \mathrm{H}$, $\left.\mathrm{NCHCH}_{2}\right), 1.82-1.97\left(\mathrm{~m}, 2 \mathrm{H}, \mathrm{NCH}_{2} \mathrm{CH}_{2}\right), 2.22-2.41\left(\mathrm{~m}, 2 \mathrm{H}, \mathrm{NCHCH}_{2}, \mathrm{NH}_{2}\right)$, $2.84(\mathrm{~d}, J=11 \mathrm{~Hz}, 1 \mathrm{H}, \mathrm{NH} 2), 3.35-3.73(\mathrm{~m}, 1 \mathrm{H}, \mathrm{NCHCH}), 3.17$ (dd, $J=9.3$, $8.5 \mathrm{~Hz}, 1 \mathrm{H}, \mathrm{CH}_{2} \mathrm{CHCH}$ ), 3.27 (dd, $J=9.3,6.9 \mathrm{~Hz}, 1 \mathrm{H}, \mathrm{PhCHCH}$ ), 3.49 (d, $J=$ $6.9 \mathrm{~Hz}, 1 \mathrm{H}, \mathrm{NCHPh}), 7.28-7.42(\mathrm{~m}, 6 \mathrm{H}, \mathrm{ArH}), 7.44-7.53(\mathrm{~m}, 4 \mathrm{H}, \mathrm{ArH})$.

${ }^{13} \mathrm{C}$-NMR: $\delta=24.1\left(\mathrm{NCH}_{2} \mathrm{CH}_{2} \mathrm{CH}_{2}\right), 25.0\left(\mathrm{NCH}_{2} \mathrm{CH}_{2}\right), 31.3\left(\mathrm{NCHCH}_{2}\right), 50.2$ ( $\mathrm{NCHCHCO}), 50.9\left(\mathrm{NCH}_{2}\right), 53.0(\mathrm{NCHCHCO}), 67.8(\mathrm{NCH}), 72.0(\mathrm{NCH})$ 126.6, 127.8, 127.9, 128.1, 128.7, 128.9, 129.2, $131.9(\operatorname{ArC}), 176.1,176.6$ (2xNCO).

MS (EI): $m / z=346\left(\mathrm{M}^{+}, 73 \%\right), 345$ (56), 269 (23), 198 (20), 173 (55), $172(100), 115(15)$

HRMS (DIP) calcd. for $\mathrm{C}_{22} \mathrm{H}_{22} \mathrm{~N}_{2} \mathrm{O}_{2}$ : 346.1681; found: 346.1668 .

\section{Acknowledgments}

The Spanish Ministerio de Ciencia e Innovación (MICINN) (projects CTQ2010-20387, and Consolider Ingenio 2010, CSD2007-00006), the Spanish Ministerio de Economia y Competitividad (MINECO) (projects CTQ2013-43446-P and CTQ2014-51912-REDC), FEDER, the Generalitat Valenciana (PROMETEO 2009/039 and PROMETEOII/2014/017), and the University of Alicante. L. C. M. thanks Spanish Government for a fellowship.

\section{Supporting Information}

YES (this text will be updated with links prior to publication)

$\left(1 S^{*}, 2 R^{*}, 3 S^{*}, 8 \mathrm{a} R^{*}\right)$-1-Nitro-2-phenyl-3-[(E)styryl]octahydroindolizine (endo-20)

Yield: $19 \mathrm{mg}(18 \%)$, brown sticky oil.

References

Template for SYNTHESIS @ Thieme Stuttgart · New York 2016-09-06 


\section{Checklist (have these on hand for manuscript submission in ScholarOne):}

- cover letter, including a statement of the work's significance

- full mailing address, telephone and fax numbers, and e-mail address of the corresponding author

- email address for each author

- original Word file

- original graphics files zipped into one zip file

- eye-catching graphical abstract as an individual file

- 5-8 key words

- separate Supporting Information file

- separate zipped Primary Data files including cover sheet (optional)

\section{Useful links:}

- SYNTHESIS homepage

- $\quad$ SYNTHESIS information and tools for authors

- Graphical abstract samples (PDF file download)

- What is "Primary Data"?

- ScholarOne (manuscript submission)

1 Michael, J. P. J. Nat. Prod., 2008, 25, 139-165.

2 (a) Pansare, S, V.; Thorat, R. G. Targets in Heterocyclic Systems 2013, 17, 57. (b) Bhat, C.; Tilve, S. G. RSC Adv., 2014, 4, 5405. (c) Bronner, S. M.; Im, G.-Y. J.; Garg. N. K. Heterocycles in Natural Product Synthesis $2011,221$. (d) Gerber-Lemaire, S.; Juillerat-Jeanneret, L. Chimia 2010, 64, 634-639.

3 Procedures employing an intramolecular cyclization affording simultaneously 5 and 6 membered rings have seldom been reported. See, for example: Brambilla, M.; Davies, S. G.; Fletcher, A. M.; Roberts, P. M.; Thomson, J. E. Tetrahedron 2014, 70, 204-211.

4 Bhat, C.; Tilve, S. G. Chem. Commun. 2014, 4, 5405-5452.

5 See, for example: (a) Pronin, S. V.; Tabor, M. G.; Jansen, D. J.; Shenvi, R. A. J. Am. Chem. Soc. 2012, 134, 2012. (b) Shapland, P. Nature Chem. 2012, 4, 441-442.

6 See, for example: (a) Vu, H.-D.; Renault, J.; Roisnel, T.; Gouault, N.; Uriac, P. Tetrahedron Lett. 2016, 57, 7, 3036-3038. (b) Tan, Y.; Chen, Y.-J.; Lin, H.; Sun, X.-W.; Yang, X. D.; Lin, G.-Q. Chem. Commun. 2014, 50, 15913-15915.

7 For general reviews dealing with general 1,3-DC, see (a) Synthetic Applications of 1,3-Dipolar Cycloaddition Chemistry towards Heterocycles and Natural Products; Padwa, A., Pearson, W. H., Eds.; John Wiley \& Sons: New Jersey, 2003; (b) Nájera, C.; Sansano, J. M. Curr. Org. Chem. 2003, 7, 1105-1150; (c) Eberbach, W. Sci. Synth. 2004, 27, chp. 11, 441. (d) Coldham, I.; Hufton, R. Chem. Rev. 2005, 105, 2765-2810; (e) Nair, V.; Suja, T. D. Tetrahedron 2007, 63, 12247-12275; (f) Padwa, A.; Bur, S. K. Tetrahedron 2007, 63, 5341-5378.

8 (a) Pearson, W. H. Pure Appl. Chem. 2002, 74, 1339-1347. (b) Pearson, W. H.; Stoy, P. Synlett 2003, $903-921$.

9 For natural product synthesis see, for example: Shanahan, C. S.; Fang, C.; Paull, D. H.; Martin, S. F. Tetrahedron 2003, 69, 7592-7607.

10 For an example dealing with a $5 \rightarrow 6$ sequence using 1,3-DC of azomethine ylides, see: Koley, D.; Srinivas, K.; Krishna, Y.; Gupta, A. RSC Adv. 2004, 4, 3934-3937.

11 Coldham, I.; Jana, S.; Watson, L.; Pilgram, C. D. Tetrahedron Lett. 2008, 49, 5408-5410. 
12 (a) Grigg, R.; Surendrakumar, S.; Thianpatanagul, S.; Vipond, D. J. Chem. Soc., Perkin Trans. 1 1988, $2693-2701$. (b) Grigg, R.; Surendrakumar, S.; Thianpatanagul, S.; Vipond, D. J. Chem. Soc., Chem. Commun. 1987, 47-49.

13 The multicomponent reaction from cyclic secondary $\alpha$-amino esters and bifunctional carbonyl compounds occurred through 1,5-H shifts followed by reaction with dipolarohiles: Grigg, R.; Rankovic, Z.; Thornton-Pett, M.; Somasunderam A. Tetrahedron 1992, 48, 10431-10442.

14 Combinations of imine-azomethine ylide-cycloaddition cascades with acid catalysed Pictet-Spengler spirocyclisation affording novel polycyclic spirocycles has been reported: Grigg, R.; Thornton-Pett, M.; Yoganathan, G. Tetrahedron 1999, 55, 8129-8140.

15 Dondas, H. A., Duraisingham, J.; Grigg, R.; MacLachlan, W. S.; MacPherson, D. T.; Thornton-Pett, M.; Sridharan, V.; Suganthan, S. Tetrahedron 2000, 56, 4063-4070.

16 Joucla, M.; Mortier, J.; Hamelin, J. Tetrahedron Lett. 1985, 26, 2775-2778

17 (a) Mancebo-Aracil, J.; Nájera, C.; Sansano, J. M. Chem. Commun. 2013, 49, 11218. (b) Sengupta, T.; Khamarui, S.; Samanta, S.; Maiti, D. K. Chem. Commun. 2013, 49, 9962. (c) Mancebo-Aracil, J.; Nájera, C.; Castelló, L. M.; Sansano, J. M.; Larrañaga, O.; de Cózar, A.; Cossío, F. P. Tetrahedron 2015, 71, 9645-9661.

18 Chaulet, Ch.; Croix, C.; Alagille, D.; Normand, S.; Delwail, A.; Favot, L.; Lecron, J.-C.; Viaud-Massuard, M.-C. Bioorg. Med. Chem. Lett. 2011, 21, 1019-1022.

19 This exo-diastereoselectivity has been observed in the synthesis of pyrrolizidines with chalcone. Biswajit Gayen, Avijit Banerji \& Kaliprasanna Dhara, Synth. Commun. 2016, DOI:10.1080/00397911.2015.1135954.

20 Available structure deposited in CCDC with number 1496416.

21 For an analogous approach using decarboxylation of proline derivatives see for example: Kang, T.-R; Cheng, Y.; He, L.; Ye, J.; Liu, Q.-Z. Tetrahedron Lett. 2012, 53, 2552-2555 and references cited therein. 